GÖTTINGER ZENTRUM

FÜR ÖKOLOGIE UND ÖKOSYSTEMFORSCHUNG

- Göttingen Centre for Ecology and Ecosystem Research -

\title{
CARBON RELEASE FROM WOODY PARTS OF TREES ALONG AN ELEVATION GRADIENT IN A TROPICAL MONTANE MOIST FOREST OF SOUTHERN ECUADOR
}

\author{
Dissertation \\ zur Erlangung des Doktorgrades \\ der Mathematisch-Naturwissenschaftlichen Fakultäten \\ der Georg-August-Universität zu Göttingen
}

vorgelegt von

Alexandra Zach

aus Coburg 
D7

Referent: Prof. Dr. Ch. Leuschner

Korreferent: apl. Prof. Dr. M. Kessler

Tag der mündlichen Prüfung: 30.April 2008 
Meiner Familie 


\section{TABLE OF CONTENTS}

\section{Introduction}

1.1 General introduction 2

Thesis aims \& Structure $\quad 3$

1.2 Plant respiration \& Components 5

1.3 Forest - Atmosphere gas exchange 8

1.4 Study sites 11

$\begin{array}{lll}1.5 & \text { References } & 14\end{array}$

2. Elevational change in woody tissue $\mathrm{CO}_{2}$ efflux in a tropical mountain $\begin{array}{lr}\text { forest in southern Ecuador } & 18\end{array}$

2.1 Abstract 19

2.2 Introduction 20

2.3 Materials \& Methods $\quad 21$

2.4 Results 26

2.5 Discussion $\quad 31$

2.6 References 35

3. Diverging temperature response of tree stem $\mathrm{CO}_{2}$ efflux to dry and wet season conditions in a tropical montane moist forest 38

3.1 Abstract $\quad 39$

3.2 Introduction 40

3.3 Materials \& Methods 42

3.4 Results 46

3.5 Discussion $\quad 50$

3.6 References 56

4. Wood $\mathrm{CO}_{2}$ efflux across an elevation transect in an Andean moist forest: Seasonality, respiration components \& stand level upscale 62

4.1 Abstract 63

4.2 Introduction $\quad 64$

4.3 Materials \& Methods $\quad 65$

4.4 Results $\quad 69$

4.5 Discussion $\quad 74$

4.6 References 
5.1 Introduction

88

5.2 Estimating C balance components of three tropical montane forests 89

5.3 The C balance of three tropical montane forests 94

5.4 References

6. Synthesis

6.1 Discussion of hypotheses

6.2 Concluding remarks

7. Summary

7.1 Summary

107

7.2 Zusammenfassung

109

7.3 Resumen

8. Appendix

114

9. Acknowledgements

10. Curriculum vitae 



\section{Chapter}

1

INTRODUCTION 


\subsection{General Introduction}

With respect to carbon (C) fluxes, tropical montane forests (TMF) are among the least studied terrestrial ecosystems (Brujinzeel and Veeneklaas 1998, Clark 2007). Covering an area of 3.3 million $\mathrm{km}^{2}$ globally or of $21.2 \%$ of the tropical forests worldwide (Bubb et al. 2004), TMFs extent along a large altitudinal zone (Jacobs 1988). The definition of the lowland border of montane forests is vague and can vary between 750 and 1650 m elevation (Jacobs 1988). Low canopy height, a high abundance of epiphytes and reduced amount of woody climbers usually distinguish TMFs from tropical lowlands. TMFs are characterized by high species diversity harbouring high numbers of endemic plants, which holds especially true for the tropical Andes (Brummit and Lughadha 2003). At higher altitudes, TMFs change into tropical montane cloud forests (TMCF) with their short-statured elfin forest vegetation. Further upslope, TMCFs are often displaced by sparse and open páramo vegetation as the upper limit.

Due to their large altitudinal extension, TMFs occur within a wide range of humidity and temperature regimes. However, all TMFs are characterized by prevailing high atmospheric humidity levels and a frequent cloud cover (Brujinzeel and Veeneklaas 1998). With regard to structure and functionality, TMFs differ considerably from tropical lowland forests. Most obvious is the marked decline in the aboveground biomass. The lower aboveground productivity of TMFs compared to the tropical lowlands has frequently been related to the lower radiation input, the lower air temperatures and the nutrient poor soils (Tanner 1985, Brujinzeel and Veeneklaas 1998, Leuschner et al. 2007, Soethe et al. 2007, Moser 2008). However, in contrast to tropical lowlands, but very similar to high latitude forests, a substantial carbon allocation to the root system was found in TMFs with increasing elevation (Brujinzeel and Veeneklaas 1998, Malhi et al. 1999, Moser et al. 2008). Our understanding of this astonishing carbon shift in TMFs is still incomplete (Brujinzeel and Veeneklaas 1998).

A comprehensive knowledge of the carbon allocation patterns in TMFs can not be achieved without information on the two key processes controlling productivity: the assimilatory $\mathrm{CO}_{2}$ uptake and the respiratory $\mathrm{CO}_{2}$ release of the forest ecosystem. Indirect information about assimilatory capacity of TMFs is implied from more readily available forest inventories with data on leaf area and productivity rates. Data on respiratory rates are very scarce and for TMFs almost non-existing. The study of $\mathrm{CO}_{2}$ release from above- and 
belowground woody organs provides a convenient framework to assess the impact of altitude and climatic fluctuations on the above- and belowground productivity of TMFs.

\section{Thesis aims \& structure}

The main objective of the present study was to quantify $\mathrm{CO}_{2}$ losses from above- and belowground woody organs (stems, coarse roots) of representative tropical montane tree species in southern Ecuador. The study was conducted along a 2000-m elevation transect and aimed to determine the impact of altitude and of seasonal climate variations on patters of $\mathrm{CO}_{2}$ release from functionally different woody organs of trees. The results will contribute to the understanding of structure and functionality of TMFs as well as provide valuable data for modeling the $\mathrm{C}$ dynamics of tropical ecosystems.

The following hypotheses have been tested in the context of this study:

(i) Apparent $\mathrm{CO}_{2}$ release from stems increases with increasing elevation from $1050 \mathrm{~m}$ to $3050 \mathrm{~m}$.

Previous studies found that the aboveground biomass production declined by a factor of 20 from $1050 \mathrm{~m}$ to $3050 \mathrm{~m}$. At the same time, it is assumed that photosynthesis does not decline proportionally. The question arises, if respiratory $\mathrm{CO}_{2}$ release is in fact related to the decreasing temperature with increasing elevation, or if increasing abiotic stress causes compensatory $\mathrm{CO}_{2}$ release from woody tissue at higher altitudes.

(ii) Apparent $\mathrm{CO}_{2}$ release from coarse roots increases with increasing elevation from $1050 \mathrm{~m}$ to $3050 \mathrm{~m}$.

The 5-fold increase in coarse root biomass production from $1050 \mathrm{~m}$ to $3050 \mathrm{~m}$ reported in previous studies represents an enormous shift in carbon allocation. This shift should be reflected in the overall respiratory activity of the coarse root system.

(iii) Apparent $\mathrm{CO}_{2}$ release rates from stems and coarse roots of TMFs at different elevation levels remain constant through the year and do not show seasonality.

Based on the general assumption of a strong temperature-dependence of respiration, an increase of respiratory activity with increasing ambient temperature should be expected. However, mean monthly temperatures fluctuate little in the study area. Additionally, tissue temperature of wood usually varies much less than air temperature.

(iv) With increasing elevation, woody tissue respiration shows an increasing relevance in the carbon balance of TMFs. At high elevations, maintenance respiration from stems and growth respiration from roots are predominant. 
Based on hypothesis (i) and (ii), it is expected that the shift in biomass between above and belowground components is reflected in the respiration rates at the stand level and in the carbon balance of the TMFs.

The present study was embedded in the DFG- research unit FOR 402 "Functionality in a tropical mountain rainforest: Diversity, dynamic processes and utilization potentials under ecosystem perspectives” (www.bergregenwald.de). As part of an interdisciplinary research project, the present study was closely linked to previous investigations conducted at the very same study sites. Data about above- and belowground biomass stocks and biomass productivity as well as detailed forest inventories (Moser 2008) could be used to estimate the stand level carbon losses from woody tree organs. Information about soil and fine root respiratory activity (Iost 2007) finally helped to derive first C-balances along the tropical montane forest gradient in southern Ecuador.

This work consists of six main chapters: Chapter 1 provides general information about plant respiration and forest gas exchange and gives an introduction of study area and sites.

Chapter 2 presents data on the variability in stem and coarse root respiration patterns with respect to altitude. Changes in the relationship between above- and belowground respiratory activity with increasing elevation are discussed.

Chapter 3 analyzes in further details the temperature response of stem respiration of montane tree species at 1890 m elevation under dry and wet season conditions. Unlike commonly expected, the changes in respiration could not be explained by differences in the thermal regime of dry and wet season. This chapter points out that respiration is driven by more factors than temperature alone and that diverging adaptation potentials of species might play an important role in explaining respiratory reaction to abiotic fluctuations in a highly diverse ecosystem.

Chapter 4 covers a whole annual cycle of respiration measurements along the elevation gradient. A clear trend towards higher $\mathrm{CO}_{2}$ release under warmer and drier climate conditions is shown for stems, but not for coarse roots. Changes in growth and maintenance respiration of stems and roots with elevation are addressed and first estimates on the annual stand carbon release of stem wood and roots are presented. Chapter 2-4 are formatted for manuscript submission.

Chapter 5 provides a preliminary $\mathrm{C}$ balance of the three study sites along the elevation gradient. Estimates are based on own measurements, literature data and previous forest inventories and soil respiration data of the three study sites. Chapter 6 summarizes the presented results and provides an overall discussion of hypotheses. 


\subsection{Plant respiration \& Components}

\subsubsection{Respiration in plants}

Although of equal importance as photosynthetic $\mathrm{CO}_{2}$ assimilation, the respiratory $\mathrm{CO}_{2}$ release has received much less attention in the attempt to determine ecosystem productivity (Chamber et al. 2004, Trumbore 2006). Photosynthesis is a distinct, light-dependent process and restricted to chloroplast-containing plant organs. Respiration, in contrast, integrates various disparate components; it is an omnipresent process, which never stops.

The respiratory activity of plants mainly comprises mitochondrial (dark-) respiration, and photo-(light-) respiration; but also futile cycles such as the alternative pathway (cyanideresistant-oxidase or alternative-oxidase). In contrast to mitochondrial respiration, photorespiration is a very specific process, which is closely linked to photosynthesis. Therefore, photorespiration is restricted to chloroplast-containing tissue; it depends on Rubisco, does not provide energy delivering products and it ceases by night. This study is dedicated to mitochondrial respiration, which in the following is referred to as respiration.

At the biochemical level, respiration is defined as the $\mathrm{CO}_{2}$ release or $\mathrm{O}_{2}$ uptake associated with the activity of glycolysis, the oxidative pentose phosphate pathway and the tricarboxylic acid (TCA) cycle. The substrate of respiration is mainly glucose and energy equivalents ( $\left.\mathrm{ADP}, \mathrm{Pi}, \mathrm{NAD}(\mathrm{P})^{+}\right)$; the glycolysis may also start with other carbohydrates, fat or sugar alcohols (Amthor 1994, Lambers et al. 2005). The product of respiration is energy (ATP, NAD(P)H) to sustain plant life and growth. Plant respiration is thought to be controlled by three processes: substrate availability, demand for energy and the potential enzyme capacity (Amthor 1995, Lambers et al. 1998, Atkin et al. 2005).

However, plants sometimes respire using the alternative oxidase, which converts most of the redox energy into heat, resulting in a much lower energy gain, but higher $\mathrm{O}_{2}$ consumption and $\mathrm{CO}_{2}$ loss than the mitochondrial respiration (Larcher 1998). Stress, injuries or senescence of tissue is supposed to stimulate alternative respiration pathways, though the significance and underlying mechanisms remain unclear (Larcher 1998, Lambers et al. 1998, Lambers et al. 2005).

Plant respiration can consume between 25 and $80 \%$ of the daily assimilated carbohydrates and hence represents an important factor in the plants' carbon balance (Amthor 2000, Lambers et al. 2005). 


\subsubsection{Growth \& maintenance respiration}

Over the past decades, respiration of plants has been partitioned into two major components: growth and maintenance respiration. Maintenance respiration $\left(\mathrm{R}_{\mathrm{m}}\right)$ is dedicated to the plants' processes for keeping the existing tissue and growth respiration $\left(\mathrm{R}_{\mathrm{g}}\right)$ to the processes for constructing new tissue (Amthor 1991). $\mathrm{R}_{\mathrm{m}}$ is supposed to be strongly correlated to the protein content of the plant. Since protein turnover and enzymatic activity is highly temperature dependent $R_{m}$ is thought to be more temperature-sensitive in contrast to the temperature-independent $\mathrm{R}_{\mathrm{g}}$ (Penning de Vries 1975a). Traditionally, the costs for new tissue are calculated straightforward from tissue composition and the energy required for constructing the components (Penning de Vries 1975b). Estimating maintenance requirements is less clearly quantifiable and assumed to be mainly a function of temperature (Lavigne 1987), nitrogen content and the volume of the tissue (phloem and xylem) it supports (Ryan et al. 1994).

However, the simplifications in the growth-maintenance-paradigm such as the assumptions of constant growth rates, invariable costs of tissue or the $\mathrm{N}$-dependence of $\mathrm{R}_{\mathrm{m}}$ have been frequently criticized (Van der Werf et al. 1992, Ryan et al. 1995, Lambers et al. 1998, Amthor 2000, Cannell and Thornley 2000, Thornley and Cannell 2000). Furthermore, it is impossible to strictly separate the various energy demanding processes between the two components. In this regard, the different processes, which comprise respiration (e.g. growth, nutrient uptake, phloem loading, symbiotic $\mathrm{N}_{2}$ fixation) and the way, these processes are partitioned among the two respiration components still require a more thorough understanding (Cannell and Thornley 2000).

\subsubsection{Respiration \& temperature}

Temperature has long been known to directly influence respiration (e.g. Amthor 1989). This influence was assumed to be exponential with a constant $Q_{10}$ of respiration ranging between 2.0 - 2.3 (e.g. Amthor 1989, Ryan 1991, Raich and Schlesinger 1992). The $\mathrm{Q}_{10}$ of respiration is the factor expressing the proportional change in respiratory $\mathrm{CO}_{2}$ release per $10 \mathrm{~K}$ rise in temperature and is calculated from the formula (e.g. Atkin et al. 2005):

$$
\mathrm{Q}_{10}=\mathrm{e}^{10 k}
$$

where $k$ is the temperature coefficient derived from non-linear regression of respiration plotted against temperature (or, alternatively, by linear regression of log-transformed respiration plotted against temperature). 
Other studies have used the Arrhenius theory to describe the response of plant respiration to temperature fluctuations (e.g. Crawford and Palin 1981, Lloyd and Taylor 1994, Griffin et al. 2002). Here, log-transformed rates of respiration are plotted against the reciprocal of temperature $(1 / \mathrm{T})$. In case of an exponential temperature-respiration relationship, the regression should be strongly linear. The slope of the line is expressed as $E_{a} / R_{g}$, where $R_{g}$ is the universal gas constant $\left(8.314 \mathrm{~J} \mathrm{~mol}^{-1} \mathrm{~K}^{-1}\right)$ and $\mathrm{E}_{\mathrm{a}}$ is the activation energy $\left(\mathrm{J} \mathrm{mol}^{-1}\right)$ for the reaction (Forward 1960). The Arrhenius model is commonly used in physical chemistry to calculate standard references of reactions. However, with regard to plant respiration this theory incorporates a series of assumptions, which were usually not matched by a complex physiological process such as respiration. Among these assumptions, the most critical are the substrate saturation of the reaction, which rarely happen in intact tissue and the implication that a single value of $E_{a}$ fits to the various specific reactions respiration is composed of (Atkin et al. 2005).

Strong respiration-temperature relationships with constant $\mathrm{Q}_{10}$ values were found under certain controlled conditions (e.g. Maier et al. 1998, Tjoelker et al. 1999, Atkin et al. 2000, Tjoelker et al. 2001, Loveys et al. 2003, Armstrong et al. 2006, Atkin et al. 2006, Atkin et al. 2007), while in the field, plant respiration responded neither constant nor necessarily exponential to changes in temperature (e.g. Edwards and McLaughlin 1978, Negisi 1982, Lavigne 1987, Gunderson et al. 2000, Teskey and McGuire 2002). Until now, neither the $\mathrm{Q}_{10}$ model nor the Arrhenius theory has been able to describe the highly variable response of respiration to changes in temperature under field conditions (Tjoelker et al. 2001, Atkin and Tjoelker 2003, Atkin et al. 2005). The response of plant respiration to changes in environmental conditions may be especially complex and far-reaching with respect to highlydiverse tropical ecosystems. In this context, the impacts of global climate change on plant respiratory activity urgently warrant further investigation. 


\subsection{Forest - Atmosphere gas exchange}

\subsubsection{Forest ecosystems \& $\mathrm{CO}_{2}$ exchange}

Quantifying the carbon exchange between forests and the atmosphere is a major topic of active research due to the key role terrestrial ecosystems play for the regulation of the anthropogenic increase in atmospheric $\mathrm{CO}_{2}$ and the associated climatic changes. The $\mathrm{CO}_{2}$ exchange of forest ecosystems is driven by two large fluxes, the photosynthetic carbon dioxide $\left(\mathrm{CO}_{2}\right)$ assimilation of green tissue and the respiratory $\mathrm{CO}_{2}$ release of autotrophic and heterotrophic organisms. Carbon balances commonly derived from two reversely operating approaches - the so called top-down or bottom-up models. While the former is based on calculations of net atmospheric $\mathrm{CO}_{2}$ fluxes, the latter comprises forest or land-use change inventories. Since the processes and carbon pools included considerably differ among both models, results upon the world's carbon balance differ as well (Malhi et al. 1999).

Estimates on the global carbon budget revealed a gross fixation of $90-130{\mathrm{Pg} \mathrm{C} \mathrm{yr}^{-1}}^{-1}$ (Bolin and Fung 1992), while soil respiration and the $\mathrm{CO}_{2}$ efflux from terrestrial plants released 64 - $72 \mathrm{Pg} \mathrm{C} \mathrm{yr}^{-1}$ (Raich and Schlesinger 1992) and 40 - $60 \mathrm{Pg} \mathrm{C} \mathrm{yr}^{-1}$ (Bolin and Fung 1992), respectively, back to the atmosphere. Compared with these large fluxes, the contribution of anthropogenic disturbance to the atmospheric $\mathrm{CO}_{2}$ concentration is a relatively small value (fossil fuel combustion $5.7 \mathrm{Gt}$; cement manufacturing $0.01 \mathrm{Gt}$; Land-use changes 3.5 Gt, http://www.whole-systems.org). Even small changes in one of the two major fluxes of carbon fixation or respiration could alter the accumulation of $\mathrm{CO}_{2}$ in the atmosphere to a much largely extent than small changes in the anthropogenic disturbance would do (Malhi and Grace 2000). Consequently, it is especially challenging to reduce the large uncertainties, which still exist concerning the magnitude of ecosystem fluxes and the fluxes from single fractions the ecosystem is composed of.

The tropical forest biome, which encompasses moist equatorial evergreen lowlands, moist deciduous, dry deciduous, montane forests and woody savannas accounts for $50 \%$ of the global forest area (FAO 1993). In total, these biomes are estimated to annually sequester $42 \mathrm{Pg} \mathrm{C}$ in biomass, which equals c. $70 \%$ of global terrestrial photosynthesis. However, terrestrial carbon emission and carbon sink terms have often been estimated as a residue of the other components comprising the global carbon budget (Malhi and Grace 2000). Applied ecological research increasingly focused on the quantification of total ecosystem $\mathrm{CO}_{2}$ release

$1 \mathrm{Pg}(1$ Petagram $)=10^{15} \mathrm{~g}=1 \mathrm{Gt}$ (Gigatonne) 
rates, which determine net ecosystem production (NEP). Consequently, estimating ecosystem respiration is an important item to identify the carbon source or sink strength of different terrestrial biomes (Malhi et al. 1999, Malhi and Grace 2000, Luyssaert et al. 2007).

\subsubsection{Measuring forest $\mathrm{CO}_{2}$ exchange}

Principally, two technical approaches are considered for determining the amount of $\mathrm{CO}_{2}$ exchange: the eddy covariance technique and chamber measurements. The recently developed eddy covariance (EC) method allows for a comprehensive measurement of $\mathrm{CO}_{2}$ exchange between large terrestrial areas and the atmosphere. EC is a high-technology, equipment-intensive method, which facilitates the quantification of net $\mathrm{CO}_{2}$ fluxes entering and leaving a system over temporally large scales (hourly to annually); highly elaborate, only few studies have been conducted in tropical regions. In addition, for capturing atmospheric $\mathrm{CO}_{2}$ this technique requires sustained high atmospheric turbulences within the system. An accumulation of $\mathrm{CO}_{2}$ below the EC measurement height due to low turbulences has often resulted in underestimates of ecosystem respiration especially during night-time, when airstreams cease. This factor particularly constraints night-time measurements in tropical forests (Grace et al. 1995, Malhi et al. 1999, Chambers et al. 2004).

While the EC technique provides valuable information about net exchange rates of the ecosystem as a whole, chamber measurements on a spatially limited area allows for the investigation of individual respiratory sources and hence, for a more physiological interpretation of carbon fluxes (Amthor 2000). Generally, the impacts of important environmental factors (e.g., temperature, humidity, radiation) can be deduced from net changes in the entire flux, but it remains unknown, which ecosystem component is the responsive one. Underlying mechanisms of flux dynamics and its driving forces can be better understood by breaking the net flux down into flux subcomponents. Within a forest ecosystem such components could comprise the two large ecosystem fluxes (heterotrophic and autotrophic), functional groups (e.g., understory, trees, palms, lianas) or single plant organs (e.g., leaves, branches, stems, roots). Information on the $\mathrm{CO}_{2}$ exchange patterns of various components is crucial if we want to gain deeper insight into the physiologically meaningful processes within a plant community and its plastic response to changing environmental conditions. 


\subsection{3 $\mathrm{CO}_{2}$ release from woody organs}

The respiration of woody parts of trees (branches, stems, coarse roots) plays a significant role for the carbon balance of forest ecosystems, since wood volume comprises a large fraction of the total biomass and considerably increases when trees age (Ryan et al. 1994, Carey et al. 1997). In mature evergreen tropical and subtropical forests, $80-90 \%$ of the dry biomass is wood (Larcher 1998). Although constituting a substantial fraction of total biomass, the aboveground woody organs respire comparatively less than other plant tissues (e.g., fine roots and leaves), when based on the dry mass (Ryan et al. 1994). This is mainly a result of the large proportion of dead tissue dominating the stem biomass, whereas the respiratory active cambial tissue is restricted to the stem outer ring under the phloem.

Traditionally, three major problems of measuring woody tissue respiration are commonly discussed in the literature and are summarized according to Sprugel et al. (1995):

- $\mathrm{CO}_{2}$ produced by respiratory activity in the sapwood may be carried away with the xylem sap flow, which, in turn, would result in an underestimation of the actual $\mathrm{CO}_{2}$ release at the measured section.

- $\mathrm{CO}_{2}$ respired by roots or taken up from the soil may be transported upwards with the xylem sap flow and additionally released somewhere further up in the stem. This would result in an overestimation of the actual $\mathrm{CO}_{2}$ release at the measured section.

- Photosynthetically active tissue in the bark may re-assimilate the $\mathrm{CO}_{2}$ produced by respiration resulting in an underestimation of the actual $\mathrm{CO}_{2}$ release rate at the measured section.

Nevertheless, independent of knowing exact sources, measuring the apparent $\mathrm{CO}_{2}$ release of woody tissue in situ is an invaluable tool to gain information about the contribution of wood to the overall carbon balance. Early studies in tropical forests estimated the fraction of wood $\mathrm{CO}_{2}$ release to range between 23 - 50\% of total plant respiration (Müller and Nielson 1965, Yoda 1967, Whitmore 1984). However, these measurements were made on excised plant organs and wound respiration most likely contributed a considerable amount to the respiratory $\mathrm{CO}_{2}$ release (Ryan et al. 1994). More recent estimates of woody tissue respiration in the tropics ranged between 10-13\% of gross production (Ryan et al. 1994, Meir and Grace 2002), though only few studies exist about the respiratory $\mathrm{CO}_{2}$ release from tropical tree stems. Even less information is available about the $\mathrm{CO}_{2}$ release of branches and coarse roots in tropical ecosystems. Small diameter wood of $<10 \mathrm{~cm}$ (including branches) contributed $70 \%$ 
to total wood respiration in an evergreen tropical lowland forest in Costa Rica (Cavaleri et al. 2006). Root respiration was found to strongly increase with decreasing diameter for Pinus radiata and Pseudotsuga menziesii. Further, seedling roots respired much faster than the roots of mature trees in Pinus radiata and Pseudotsuga menziesii (Hollinger et al. 1994).

\subsection{Study sites}

The three study sites are located within the Podocarpus National Park at the eastern slopes of the southern Andes of Ecuador (Figure 1.1). The park is situated between the two provinces Loja and Zamora covering an area of 1460 km² (Calderón 2002).

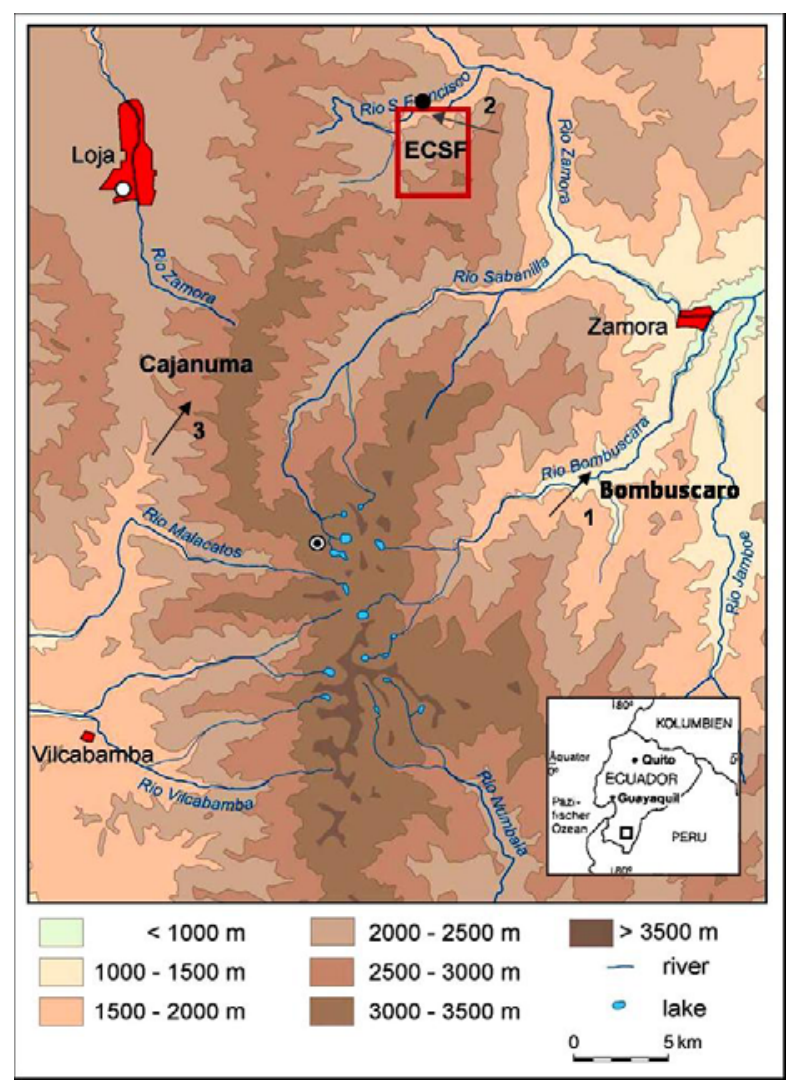

Figure 1.1. Study area and location of the three study sites: 1 Bombuscaro (premontane) at $1050 \mathrm{~m}$ asl, 2 ECSF (lower montane) at $1890 \mathrm{~m}$ asl, and 3 Cajanuma (upper montane) at $3050 \mathrm{~m}$ asl. The whole area covered by the research station (ECSF) is also indicated.

At its northern limit, in the valley of the Rio San Francisco, the research station "Reserva San Francisco” (RSF, formerly ECSF) borders the National Park. The Reserva, covering an area of about 1000 ha, is owned by the foundation Nature and Culture International (NCI), Ecuador and is rented by the DFG for the ongoing investigations of the research unit FOR 402. Emerging between the humid Amazon basin and the dry inter-Andean valley, the area encloses various tropical montane forest ecosystems (Richter 2003). The 
montane vegetation includes premontane tropical forest at its lower limit (c. $1000 \mathrm{~m}$ elevation) up to upper montane cloud forest (TMCF) and the páramo. In this area, the timberline is reached at $3100 \mathrm{~m}$ a.s.l. ( $\pm 200 \mathrm{~m}$ ) (Richter 2003).

The vegetation is mainly evergreen broad-leaved. Few deciduous tree species (e.g. Tabebuia chrysantha, Cedrela montana) and one conifer species (Podocarpus oleifolia) occur in the study area (Homeier 2004).

The climate of the study area is strongly influenced by the extremely patchy topography of the Andean mountains. The rainfall gradient along the altitudinal extension of the Reserva is steep and amounts of annual precipitation increase tremendously from c. 2000 $\mathrm{mm}$ at $960 \mathrm{~m}$ a.s.l. (Zamora) to c. $7780 \mathrm{~mm}$ at $3185 \mathrm{~m}$ a.s.l. (Cerro del Consuelo, Las Antenas). Fog water input plays a minor role at $1800 \mathrm{~m}$, but increases to $30 \%$ of total water input at Cerro del Consuelo (Fabian et al. 2005). The high cloud frequency at the eastern Andean slopes causes a humid climate throughout the year with peak rainfalls between May and July. The prevailing humid climate is interrupted by a short, less humid period between November and February, when westerly foehn winds induce dry and sunny weather conditions (Bendix and Lauer 1992). Mean annual temperature is $19.4{ }^{\circ} \mathrm{C}$ at $1000 \mathrm{~m}$ and decreases by $0.59 \mathrm{~K} 100 \mathrm{~m}^{-1}$ (Richer 2003). Mean monthly temperatures are more or less constant throughout the year; the warmest months November and the coolest months April differ by 1.9 - 2.4K (Röderstein et al. 2005). However, daily minimum and maximum temperatures during the less humid season can differ by more than 20K (Moser 2008). Temperature never reaches $0{ }^{\circ} \mathrm{C}$ throughout the study area.

The soils of the study area developed on metamorphic shale, quartzite or sandstone bedrock. According to FAO taxonomy, soils at $1000 \mathrm{~m}$ are classified as alumic Acrisols, at $1900 \mathrm{~m}$ as gleyic Cambisols and as Podzols at $3000 \mathrm{~m}$ (Iost 2007). At $3050 \mathrm{~m}$, the organic layer is markedly thick (about $430 \mathrm{~mm}$ ), whereas at $1050 \mathrm{~m}$ only the upper $50 \mathrm{~mm}$ are organic material. Characteristically for the soils of the study sites are the generally low cation exchange capacity and the low pH (2.9 - 3.9) resulting in an overall low fertility (Iost 2007).

The three sites chosen for this particular study are distributed along a 2000-m elevation gradient and are located with a distance of $30 \mathrm{~km}$ between stands (Figure 1.1). All sites are on gentle slopes (26-31 $)$ facing north-east or north-west (Moser 2008). The lowelevation site $\left(1050 \mathrm{~m}, \mathrm{~S} 04^{\circ} 06^{`} 54^{\prime}\right.$ / W $\left.78^{\circ} 58^{\circ} 02^{\prime \prime}\right)$ is close to the north-eastern entrance of the Podocarpus National Park (Bombuscaro section) in the province of Zamora-Chinchipe (Figure 1.1). This premontane forest is dominated by tree species from the families 
Myrtaceae, Sapotaceae (mainly Pouteria), Annonaceae (Guatteria), Moraceae (Ficus) and Mimosaceae (Inga) (Figure 1.2). Trees are taller than further upslope, reaching a canopy heights of $31.8 \mathrm{~m}$, with maximum stem length of $39.7 \mathrm{~m}$ (mean: $15.6 \mathrm{~m} \pm 0.7 \mathrm{SE}$, Moser 2008).

The mid-elevation site $\left(1890 \mathrm{~m}, \mathrm{~S} 03^{\circ} 58^{`} 345^{` ` /} \mathrm{W} 79^{\circ} 04^{`} 648^{` \prime}\right)$ is close to the Reserva San Francisco (RSF), $30 \mathrm{~km}$ from Loja on the road to Zamora, Province of ZamoraChinchipe (Figure 1.1). In this lower montane vegetation the tree families Melastomataceae (mainly Graffenrieda emarginata and Miconia), Lauraceae (Ocotea), Euphorbiaceae (Alchornea), Rubiaceae (Palicourea) and Chletraceae (Chlethra) are most abundant (Figure 1.2). Canopy height is $18.9 \mathrm{~m}$, with a maximum stem length of $24.8 \mathrm{~m}$ (mean: $10.1 \mathrm{~m} \pm 0.4$ SE, Moser 2008).

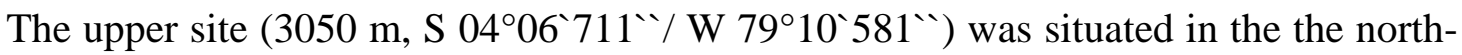
western section of the Park, Cajanuma, Province of Loja (Figure 1.1). This upper montane vegetation is charcterized by trees from the families Cunnoniaceae (Weinmannia), Rubiaceae (Faramea), Clusiaceae (Clusia), Ericaceae and Symplocacaceae (Figure 1.2). Canopy height is $9.0 \mathrm{~m}$, with a maximum stem length of $19.2 \mathrm{~m}$ (mean: $5.2 \mathrm{~m} \pm 0.3 \mathrm{SE}$, Moser 2008).
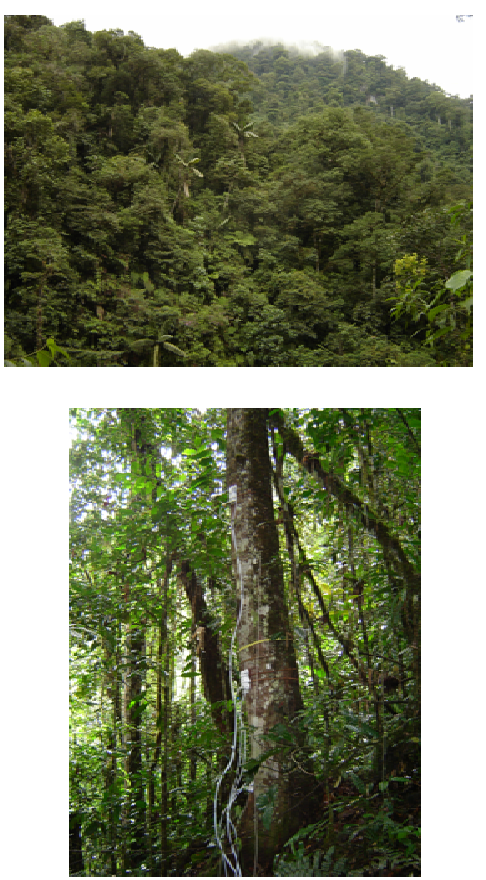

$1050 \mathrm{~m}$
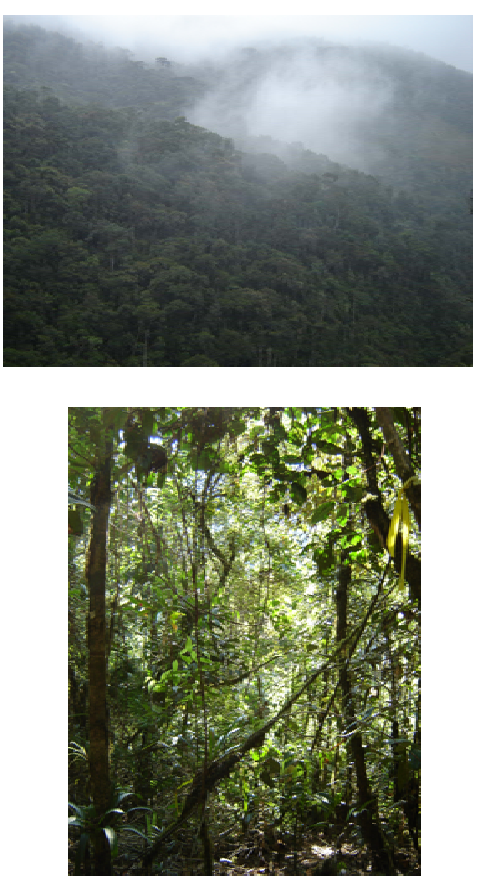

$1890 \mathrm{~m}$
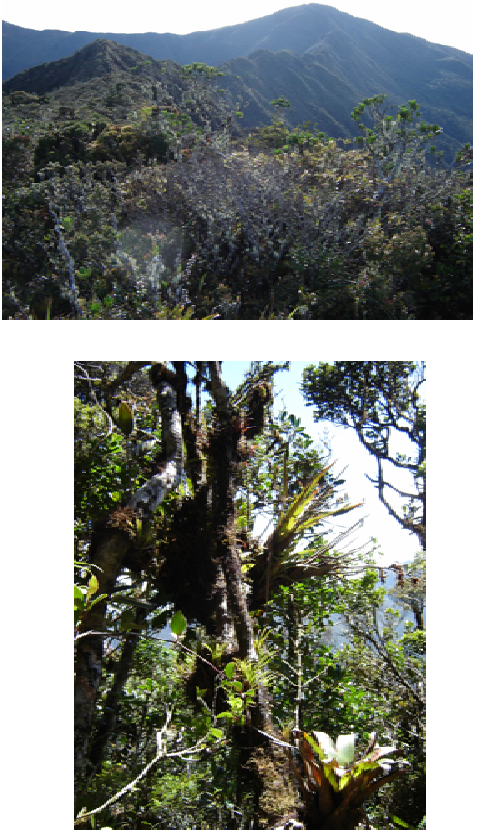

$3050 \mathrm{~m}$

Figure 1.2. The three study sites at $1050 \mathrm{~m}$ (premontane), $1890 \mathrm{~m}$ (lower montane) and 3050 m (upper montane). Views from outside (above) and inside (below) the sites. 


\subsection{References}

Amthor JS (1989) Respiration and crop productivity. Springer-Verlag, New York, USA, pp. 215.

Amthor JS (1991) Respiration in a future, higher- $\mathrm{CO}_{2}$ world. Plant Cell and Environment 14, 13-20.

Amthor JS (1994) Plant respiratory responses to the environment and their effects on the carbon balance. In: Plant-environment interactions. (ed. Wilkinson RE). Marcel Dekker, New York, pp. 501-554.

Amthor JS (1995) Terrestrial higher-plant response to increasing atmospheric $\mathrm{CO}_{2}$ in relation to the global carbon cycle. Global Change Biology 1, 243-274.

Amthor JS (2000) The McCree-de Wit-Penning de Vries-Thornley respiration paradigms: 30 years later. Annals of Botany 86, 1-20.

Armstrong AF, Logan DC, Atkin OK (2006) On the developmental dependence of leaf respiration: responses to short- and long-term changes in growth temperature. American Journal of Botany 93, 11, 1633-1639.

Atkin OK, Holly C, Ball MC (2000) Acclimation of snow gum (Eucalyptus pauciflora) leaf respiration to seasonal and diurnal variations in temperature: the importance of changes in capacity and temperature sensitivity of respiration. Plant Cell and Environment 23, 15-26.

Atkin OK, Tjoelker MG (2003) Thermal acclimation and the dynamic response of plant respiration to temperature. Trends in Plant Science 8, 343-351.

Atkin OK, Bruhn D, Hurry VM, Tjoelker MG (2005) The hot and the cold: unravelling the variable response of plant respiration to temperature. Functional Plant Biology 32, 87105.

Atkin OK, Scheurwater I, Pons TL (2006) High thermal acclimation potential of both photosynthesis and respiration in two lowland Plantago species in contrast to an alpine congeneric. Global Change Biology 12, 500-515.

Atkin OK, Scheurwater I, Pons TL (2007) Respiration as a percentage of daily photosynthesis in whole plants is homeostatic at moderate, but not high, growth temperatures. New Phytologist 174, 367-380.

Bendix J, Lauer W (1992) Die Niederschlagsjahreszeiten in Ecuador und ihre klimadynamische Interpretation. Erdkunde 46, 118-134.

Bolin B, Fung I (1992) Report: the carbon cycle revisited. In: Modelling the earth system. (ed: Boulder OD), USA: UCAR/Office for Interdisciplinary Earth Studies, 151-164.

Brujinzeel LA, Veneklaas EJ (1998) Climatic conditions and tropical montane forest productivity: The fog is not lifted yet. Ecology 79, 3-9.

Brummit N, Lughadha EN (2003) Biodiversity: where's hot and where's not hot. Conservation Biology 17, 1442-1448.

Bubb P, May I, Miles L, Sayer J (2004) Cloud forest agenda. URL:http//www.unepwcmc.org/resources/publications/UNEP_WCMC_bio_series/20.htm.

Hamilton LS, Juvik JO, Scatena F (1995) Tropical montane cloud forests. Springer, New York. 
Calderón S (2002) El Parque Nacional Podocarpus y fundamentos legales que lo respaldan. In: Botánica Austroecuadoriana. Estudios sobre los recursos vegetales en la provincial de el Oro, Loja y Zamora-Chinchipe. (eds.: Aguirre MZ, Madsen JE, Cotton E, Balslev H), Ediciones Bya-Yala, Quito, Ecuador, pp. 433-451.

Cannell MGR, Thornley JHM (2000) Modelling the components of plant respiration: some guiding principles. Annals of Botany 85, 45-54.

Carey EV, Callaway RM, DeLucia EH (1997) Stem respiration of ponderosa pines grown in contrasting climates: implications for global climate change. Oecologia 111, 19-25.

Cavaleri MA, Oberbauer SF, Ryan MG (2006) Wood $\mathrm{CO}_{2}$ efflux in a primary tropical rain forest. Global Change Biology 12, 2442-2458.

Chambers JQ, Tribuzy ES, Toledo LC, Crispim BF, Higuchi N, Dos Santos J, Araújo AC, Kruijt B, Nobre AS, Trumbore SE (2004) Respiration from a tropical forest ecosystem: Partitioning of sources and low carbon use efficiency. Ecological Applications 14, 72-88.

Clark DA (2007) Detecting tropical forests' responses to global climatic and atmospheric changes: current challenges and a way forward. Biotropica 39, 4-19.

Crawford RMM, Palin MA (1981) Root respiration and temperature limits to the north-south distribution of four perennial maritime plants. Flora 171, 338-354.

Edwards NT, McLaughlin SB (1978) Temperature-independent diel variations of respiration rates in Quercus alba and Liriodendron tulipifera. Oikos 31, 200-2006.

Fabian P, Kohlpaintner M, Rollenbeck R. (2005) Biomass burning in the Amazon - Fertilizer for the mountaineous rain forest in Ecuador, Environmental Science and Pollution Research 12, 290-296.

Forward DF (1960) Effect of temperature on respiration. In: Encyclopedia of plant physiology Vol 12. (ed. Ruhland W), Springer-Verlag, Berlin, Germany, pp. 234-258.

Grace J, Lloyd J, McIntyre J, Miranda AC, Meir P, Miranda HS, Nobre C, Moncreiff J, Massheder J, Malhi Y, Wright I, Gash J (1995) Carbon dioxide uptake by an undisturbed tropical rain forest in southwest Amazonia, 1992 to 1993. Science 270, 778-780.

Griffin KL, Turnball M, Murthy R (2002) Canopy position affects the temperature response of leaf respiration in Populus deltoides. New Phytologist 154, 609-619.

Gunderson CA, Norby RJ, Wullschläger SD (2000) Acclimation of photosynthesis and respiration to simulated climatic warming in northern and southern populations of Acer saccharum: laboratory and field evidence. Tree Physiology 20, 87-96.

Hollinger DY, Kelliher F M, Byers JN, Hunt JE, McSeveny TM, Weir PL (1994) Carbon dioxide exchange between an undisturbed old-growth temperate forest and the atmosphere. Ecology 75, 134-150.

Homeier J (2004) Baumdiverstät, Waldstruktur und Wachstumsdynamik zweier tropischer Bergregenwälder in Ecuador und Costa Rica. Dissertationes Botanicae 391, pp. 207.

Iost S (2007) Soil respiration, microbial respiration and mineralization in soils of montane rainforests of southern Ecuador: influence of altitude. PhD Thesis, TU Dresden, Germany, pp. 171.

Jacobs M (1988) The tropical rain forest - a first encounter. Springer-Verlag, Berlin, Germany, pp. 295.

Lambers H, Chapin FS, Pons TI (1998) Plant physiological ecology. Springer-Verlag, New York, pp. 540. 
Lambers H, Ribas-Carbo M (eds.) (2005) Advances in photosynthesis and respiration. Volume 18: Plant respiration: From cell to ecosystem. Springer, Netherlands, pp. 250.

Lavigne MB (1987) Differences in stem respiration response to temperature between balsam fir trees in thinned and unthinned stands. Tree Physiology 3, 225-233.

Larcher W (1998) Physiological plant ecology. Springer Verlag, Berlin, Germany, pp. 513.

Lloyd J, Taylor JA (1994) On the temperature dependence of soil respiration. Functional Ecology 8, 315-323.

Loveys BR, Atkinson LJ, Sherlock DJ, Roberts RL, Fitter AH, Atkin OK (2003) Thermal acclimation of leaf and root respiration: an investigation comparing inherently fast- and slow-growing plant species. Global Change Biology 9, 895-910.

Luyssaert S, Inglima I, Jung M, Richardson AD, Reichstein M, Papale D, Piao SL, Schulze ED, Wingate L, Matteucci G, Aragao L, Aubinet M, Beer C, Bernhofer C, Black KG, Bonal D, Bonnefond FM, Chambers J, Ciais P, Cook B, Davis KJ, Dolman AJ, Gielen B, Goulden M, Grace J, Granier A, Grelle A, Griffis T, Grünwald T, Guidolotti G, Hanson PJ, Harding R, Hollonger DY, Hutyra LR, Kolari P, Kruijt B, Kutsch W, Lagergen F, Laurila T, Law BE, LeMaire G, Lindroth A, Loustau D, Malhi Y, Mateus J, Migliavacca M, Misson L, Montagnani L, Moncrieff J, Moors E, Munger, Nikinmaa E, Ollonger SV, Pita G, Rebmann C, Roupsard O, Saigusa N, Sanz MJ, Seufert G, Sierra C, Smith ML, Tang J, Valentini R, Vesala T, Janssens IA (2007) $\mathrm{CO}_{2}$ balance of boreal, temperate, and tropical forests derived from a global database. Global Change Biology 13, 2509-2537.

Maier TA, Zarnoch SJ, Dougherty PM (1998) Effects of temperature and tissue nitrogen on dormant season stem and branch respiration in a young loblolly pine (Pinus tadea) plantation. Tree Physiology 18, 11-20.

Meir P, Grace J (2002) Scaling relationship for woody tissue respiration in two tropical rain forests. Plant, Cell and Environment 25, 963-973.

Moser G (2008) Elevation effects on key processes of carbon cycling in South Ecuadorian mountain forests. PhD Thesis. University of Göttingen, Germany, pp.125.

Müller D, Nielson J (1965) Production brute, pertes par respiration e production nette dans la foret ombrophile tropicale. Forstlige Forsøgsvaesen i Danmark 29, 69-160.

Negisi K (1982) Dirunal fluctuations in the stem bark respiration in relationship to the wood temperature in standing young Pinus densiflora, Chamaecyparis obtusa and Quercus myrsinaefolia trees. Journal of Japanese Forest Society 64, 315-319.

Penning de Vries FWT (1975a) The cost of maintenance processes in plant cells. Annals of Botany 39, 77-92.

Penning de Vries FWT (1975b) Use of assimilates in higher plants. In: Photosynthesis and productivity in different environments. (ed: Cooper JG). Cambrigde University Press, Cambridge, pp. 459-480.

Raich JW, Schlesinger WH (1992) The global carbon-dioxide flux in soil respiration and its relationship to vegetation and climate. Tellus, Series B - Chemical and Physical Meteorology 44, 81-99.

Richter M (2003) Using epiphytes and soil temperature for eco-climatic interpretation in southern Ecuador. Erdkunde 57, 161-181.

Röderstein M, Hertel D, Leuschner C (2005) Above- and below-ground litter production in three tropical mountain forests (South Ecuador). Journal of Tropical Ecology 21, 483-492. 
Ryan MG (1991) Effect of climate change on plant respiration. Ecological Applications 1, 157-167.

Ryan MG, Hubbard RM, Clark DA, Sanford RL Jr (1994) Woody-tissue respiration of Simarouba amara and Minquartia guinensis, two wet forest trees with different growth habits. Oecologia 100, 213-220.

Ryan MG, Gower ST, Hubbard RM, Waring RH, Gholz HL, Cropper WP, Running SW, (1995) Woody tissue maintenance respiration of four conifers in contrasting climates. Oecologia 101, 133-140.

Sprugel DG, Ryan MG, Brooks JR, Vogt KA, Martin TA (1995) Respiration from the organ to the stand. In: Resource physiology of conifers. Acquisition, allocation and utilization. (eds: Smith WK, Hickley TM). Academic press, San Diego, pp. 255-299.

Teskey RO, McGuire MA (2002) Carbon dioxide transport in xylem causes errors in estimation of rates of respiration in stems and branches of trees. Plant Cell and Environment 25, 1571-1577.

Thornley JHM, Cannell MGR (2000) Modelling the components of plant respiration: representation and realism. Annals of Botany 85, 55-67.

Tjoelker MG, Oleksyn J, Reich PB (1999) Acclimation of respiration to temperature and CO2 in seedlings of boreal tree species in relation to plant size and relative growth rate. Global Change Biology 49, 679-691.

Tjoelker MG, Oleksyn J, Reich PB (2001) Modelling respiration of vegetation: evidence for a general temperature-dependent $\mathrm{Q}_{10}$. Global Change Biology 7, 223-230.

Trumbore S (2006) Carbon respired by terrestrial ecosystems - recent progress and challenges. Global Change Biology 12, 141-153.

Van der Werf A, Van den Berg G, Ravenstein HJL, Lambers H, Eisberg R (1992) Protein turnover: A significant component of maintenance respiration in roots? In: Molecular, biochemical and physiological aspects of plant respiration. (eds. Lambers $\mathrm{H}$, Van der Plas LHW). SPB Academic Publishing, The Hague, pp. 61-77.

Whitmore TC (1984) Tropical rainforests of the Far East. $2^{\text {nd }}$ Edn. Clarendon Press Oxford, pp. 351.

Yoda K (1967) Comparative ecological studies on three main types of forest vegetation in Thailand. III. Community Respiration. Nature Life SE Asia 5, 83-148. 


\section{Chapter}

2

\section{Elevational Changes in WoOdy Tissue $\mathrm{CO}_{2}$ EFFluX}

IN A TROPICAL MOUNTAIN RAIN FOREST IN

SOUTHERN ECUADOR

AleXANDra ZaCh, Viviana Horna AND Christoph Leuschner

Tree Physiology 28: 67-74 (2008) 


\subsection{Abstract}

Much uncertainty exists about the magnitude of woody tissue respiration and its environmental control in highly diverse tropical moist forests. In a tropical mountain rainforest in southern Ecuador, we measured the apparent diurnal gas exchange of stems and coarse roots $(\mathrm{d}: 1-4 \mathrm{~cm})$ of trees from representative families along an elevational transect with plots at 1050, 1890 and $3050 \mathrm{~m}$ a. s. 1.. Mean air temperatures were 20.8, 17.2 and 10.6 ${ }^{\circ} \mathrm{C}$, respectively. Stem and root $\mathrm{CO}_{2}$ efflux of 13 to 21 tree individuals per stand from dominant families were investigated with an open gas exchange system while stand microclimate was continuously monitored. Substantial variation in respiratory activity among different species and different tree individuals was found at all sites. Mean daily $\mathrm{CO}_{2}$ release rates from stems $\left(\mathrm{R}_{\mathrm{S}}\right)$ declined 6.6-fold from $1.38 \mu \mathrm{mol} \mathrm{m} \mathrm{m}^{-2}$ at $1050 \mathrm{~m}$ to $0.21 \mu \mathrm{mol} \mathrm{m}^{-2} \mathrm{~s}^{-1}$ at $3050 \mathrm{~m}$. Mean daily $\mathrm{CO}_{2}$ release from coarse roots $\left(\mathrm{R}_{\mathrm{R}}\right)$ showed a decreasing tendency from 0.35 to $0.20 \mu \mathrm{mol} \mathrm{m} \mathrm{m}^{-2} \mathrm{~s}^{-1}$ with altitude, but the differences were not significant. There was, thus, a remarkable shift from a relatively high respiratory activity of stems compared to coarse roots at lower montane elevation to an apparent equivalence of stem and coarse root $\mathrm{CO}_{2}$ efflux rates at high elevation occurred. We conclude that stem respiration, but not root respiration, greatly decreases with elevation in this transect, coinciding with a substantial decrease in relative stem diameter increment and a large increase in fine and coarse root biomass production with elevation.

Keywords: altitudinal transect, coarse root respiration, infrared gas analysis, stem respiration, temperature dependence 


\subsection{Introduction}

Plant tissue respiratory activity is thought to consume $30-80 \%$ of the daily assimilated carbon gain (Amthor 2000), constituting one of the main sources of $\mathrm{CO}_{2}$ released to the atmosphere (Trumbore 2006). Although the carbon balance of forests is in the focus of current global change research, the respiration of stems, branches and coarse roots is one of the least studied processes (Sprugel and Benecke 1991). Knowledge of tropical forest respiration is particularly sparse, despite their acknowledged importance of tropical forests in the global carbon balance (Meir and Grace 2002, Chambers et al. 2004). For reliable modeling of the carbon sink strength of tropical forests in a changing climate, a detailed knowledge of plant respiration is needed, particularly its variability among forest types, and its dependence on the environment. The few in situ measurements of respiration of tropical forest trees indicate that woody tissue respiration accounted for $10-13 \%$ of gross photosynthesis (Ryan et al. 1994, Meir and Grace 2002). Earlier measurements in tropical forests based on observations of $\mathrm{CO}_{2}$ release from excised plant organs yielded values between 23 and 50\% (Müller and Nielson 1965, Yoda 1967, Whitmore 1984).

To our knowledge, only one gas exchange study has been conducted in tropical highelevation forests until now: Cavieres et al. (2000) measured leaf gas exchange of two tree species in the Venezuelan Andes. Studies quantifying woody tissue respiration along altitudinal transects in tropical mountain forests are lacking. Information from such studies would help to predict effects of temperature change on plant respiration in tropical ecosystems. Woody tissue $\mathrm{CO}_{2}$ release rates can vary enormously, not only among different forest types (Lavigne et al. 1996, Ryan et al. 1997), but also among species within a stand and among individuals of the same species (Meir and Grace 2002). Information on the spatial variability of woody tissue respiration is indispensable when extrapolating gas flux data from tree to stand. This information is particularly important in tropical forests with their high species richness and large structural variability across environmental gradients (Meir and Grace 2002, Chambers et al. 2004).

The current study was undertaken to: (1) quantify species-specific differences in woody tissue respiration in tropical mountain forests; (2) compare the respiratory activity of stems and coarse roots; and (3) analyze changes in stem and root respiration along an altitudinal span of $2000 \mathrm{~m}$ in a tropical mountain rainforest in southern Ecuador. 


\subsection{Materials \& Methods}

\subsubsection{Study sites}

The study was carried out in Podocarpus National Park (PNP) in the surroundings of Loja on the eastern slopes of the southern Ecuadorian Andes. We chose three forest stands along an altitudinal gradient ranging from $1050 \mathrm{~m}$ to $3050 \mathrm{~m}$ a. $\mathrm{s}$. 1 . The maximum distance between the stands was about $30 \mathrm{~km}$. The low-elevation stand $\left(1050 \mathrm{~m}, \mathrm{~S} 04^{\circ} 06^{\prime} 54^{\prime \prime} / \mathrm{W}\right.$ $\left.78^{\circ} 58^{\circ} 02^{\prime \prime}\right)$ is located in the northeastern part of PNP (Bombuscaro section) in the Province of Zamora-Chinchipe. The mid-elevation stand (1890 m, S $\left.03^{\circ} 58^{\prime} 345^{\prime \prime} / \mathrm{W} 79^{\circ} 04^{\prime} 648^{\prime \prime}\right)$ is close to the Estacion Cientifica San Francisco (ECSF), $30 \mathrm{~km}$ from Loja on the road to Zamora, Province of Zamora-Chinchipe. The high-elevation stand $\left(3050 \mathrm{~m}, \mathrm{~S} 04^{\circ} 06^{\prime} 711^{\prime}\right.$ '/ W $\left.79^{\circ} 10^{\prime} 581^{\prime \prime}\right)$ is in the Cajanuma area in the northwestern part of PNP, Province of Loja. All stands were selected on gentle slopes $\left(26-31^{\circ}\right)$ facing northeast to northwest, covering an area of $20 \times 20 \mathrm{~m}$.

The climate of the area is mainly influenced by easterly winds that bring frequent rainfall throughout the year with peaks from May to July. During our study, conducted from October to December 2005, westerly winds strongly influenced the local weather causing a relatively dry and sunny period in the study area.

The soils of the area developed either from grandiosities (low-elevation stand), or metamorphic shale, quartzite and sandstone bedrock (mid- and high-elevation stands). Throughout the study region, the soils are relatively infertile (Schrumpf et al. 2001).

\section{Forest structure and selection of tree individuals}

The stands were selected to: a) be representative of the vegetation type at each elevation; b) have a closed canopy within a surrounding area of $100 \times 100 \mathrm{~m}$; and c) be free of recent anthropogenic influence or landslide disturbance. The low-elevation stand $(1050 \mathrm{~m})$ represents the transitional zone between tropical lowland and lower montane rainforest. The mid-elevation stand $(1890 \mathrm{~m})$ is a typical lower montane rain forest, and the high-elevation stand $(3050 \mathrm{~m})$ is located close to the timberline and represents a typical "elfin forest" characterized by stunted trees with warped stem forms. Further details on forest structure are given in Table 2.1. All plots have been previously studied and described by Röderstein et al. (2005), Leuschner et al. (2007) and Moser et al. (2008). 
Table 2.1. Climate and stand structure characteristics of the study sites at 1050, 1890 and $3050 \mathrm{~m}$ (data from Moser et al. 2008, means with standard deviation in parenthesis). Mean air temperature and mean relative humidity were recorded inside the stands at a height of $2 \mathrm{~m}$. Rainfall data are extrapolated from measurements in gaps at about $1050 \mathrm{~m}$ (G. Moser, in press), $1950 \mathrm{~m}$ and $3170 \mathrm{~m}$ (Emck 2007). Abbreviations: AGB, aboveground biomass; BGB, belowground biomass.

\begin{tabular}{lrrr}
\hline Parameter & $1050 \mathrm{~m}$ & $1890 \mathrm{~m}$ & $3050 \mathrm{~m}$ \\
\hline Air temperature $\left({ }^{\circ} \mathrm{C}\right)$ & $20.8(3.3)$ & $16.8(4.4)$ & $10.6(3.1)$ \\
Relative humidity $(\%)$ & $87.3(16.1)$ & $87.4(21.9)$ & $91.0(13.0)$ \\
Precipitation $\left(\mathrm{mm} \mathrm{yr}^{-1}\right)$ & 2230 & 1950 & 4500 \\
DBH $(\mathrm{cm})$ & $17.3(1.3)$ & $12.2(0.8)$ & $7.2(0.4)$ \\
Stem height $(\mathrm{m})$ & $15.6(0.7)$ & $10.1(0.4)$ & $5.2(0.3)$ \\
Basal area $\left(\mathrm{m}^{2} \mathrm{ha}^{-1}\right)$ & 33.6 & 36.9 & 42.2 \\
Stem density $\left(\mathrm{n} \mathrm{ha}^{-1}\right)$ & 968 & 2333 & 8317 \\
LAI & $6.0(0.4)$ & $5.7(0.5)$ & $2.2(0.2)$ \\
Wood density $\left(\mathrm{g} \mathrm{cm}^{-3}\right)$ & $0.64(0.15)$ & $0.60(0.16)$ & $0.69(0.15)$ \\
Stand leaf mass $\left(\mathrm{Mg} \mathrm{ha}^{-1}\right)$ & $6.82(0.44)$ & $9.74(0.83)$ & $3.64(0.29)$ \\
AGB $\left(\mathrm{Mg} \mathrm{ha}^{-1}\right)$ & 285.1 & 173.0 & 112.2 \\
BGB $\left(\mathrm{Mg} \mathrm{ha}^{-1}\right)$ & 32.1 & 25.8 & 62.7 \\
\hline
\end{tabular}

In each stand, a minimum of 80 canopy trees were identified at the species level. As long as they reached the canopy, trees smaller than $5 \mathrm{~cm} \mathrm{DBH}$ (diameter at breast height) were included in the samples. To measure $\mathrm{CO}_{2}$ release rates of woody organs, 13 to 21 trees per stand were selected (Appendix 1). We required that trees belong to abundant families in the particular stand and comprise a broad range of DBH classes in order to represent the floristic composition and size heterogeneity of the stand. Thus, each sample consisted of trees from 10-11 families. At the mid- and low-elevation stands, we included more trees $(\mathrm{n}=20$ and 21 , respectively) to account for the wider diameter range than in the high-elevation stand $(\mathrm{n}=13)$. Diameter of the selected trees ranged from 8.70 to $43.85 \mathrm{~cm}$ at $1050 \mathrm{~m}$, from 3.02 to $26.47 \mathrm{~cm}$ at $1890 \mathrm{~m}$ and from 2.48 to $17.67 \mathrm{~cm}$ at $3050 \mathrm{~m}$. We measured $4-8$ coarse roots (diameter: 1-4 cm) at each site depending on accessibility. 


\subsubsection{Gas exchange measurements}

Woody tissue $\mathrm{CO}_{2}$ release rates were measured in situ between October to December 2005 , which corresponds to the drier season of the year, although each month received at least $80 \mathrm{~mm}$ of rain. In each stand, the measurements were made over a 10-day period, during which continuous measurements were made of $\mathrm{CO}_{2}$ efflux from woody organs (stems and coarse roots). Stem $\mathrm{CO}_{2}$ release was monitored at breast height $(1.3 \mathrm{~m})$ using transparent plexiglas chambers $\left(95.1 \mathrm{~cm}^{3}\right.$ volume) tightly fitted onto the bark surface (Appendix 2$)$. When necessary, mosses and lichens were cautiously removed from the measured stem segment using a soft brush, carefully avoiding damage to the bark. Segments of coarse roots were enclosed in transparent plexiglas chambers of $473.8 \mathrm{~cm}^{3}$ volume fixed around the organ with staunching rings and sealed using Terostat ${ }^{\circledR}$ VII (Teroson, Henkel AG, Düsseldorf, Germany). The cylindrical chamber design allows for the measurement of organ sections ranging in diameter from 1 to $4 \mathrm{~cm}$. Both types of chambers have a relatively small volume and are designed with inlet and outlet nozzles at opposite sides in order to ensure adequate mixing of the incoming air. Air-tightness of the measurement chambers was controlled via electronic air flow meters.

The diameter of the stems or roots was measured in the middle of the organ section enclosed in the chamber. The surface temperature of the measured organ section was recorded with thermocouples attached on the outside of the stem surface next to the chamber. We selected coarse roots $(\mathrm{d}: 1-4 \mathrm{~cm})$ growing a few centimetres beneath the soil surface and uncovered the root section to be measured with a soft brush.

\section{Gas exchange system}

Net exchange of $\mathrm{CO}_{2}$ across stem or root surfaces was measured with a mobile 6chamber respiration system ANARESY 2 (Walz, Effeltrich, Germany; Appendix 2) with an integrated infrared gas analyzer for $\mathrm{CO}_{2}$ and $\mathrm{H}_{2} \mathrm{O}$ (LI-7000, Li-Cor, Inc., Lincoln, NE). The open gas exchange system was operated in differential mode (Ryan et al. 1995) and allows for continuous diurnal measurements of the apparent $\mathrm{CO}_{2}$ release rate in six plexiglas chambers (Horna and Zimmermann 2000). Buffered incoming air permanently passed all six chambers with a maximum flow rate of $11 \mathrm{~min}^{-1}$.

Every $6 \mathrm{~min}$, the system switched automatically from one chamber to the next, thus recording about two $\mathrm{CO}_{2}$ release values per chamber per hour. The six chambers were moved to different tree individuals after completing a 24-hour measurement cycle. Electrical power 
was supplied by a generator that charged car batteries connected in series ( $24 \mathrm{~V} \mathrm{DC})$. The generator was placed at a distance of over $100 \mathrm{~m}$ from the measuring system to avoid any influence of the fumes on the measurement. For every 10-day measurement interval, the entire set up was moved to the next site. The weather conditions during the measuring period from October to December 2005 were sufficiently stable to allow for a comparison of the three stands.

\section{Calculation of respiration rates}

The LI-7000 infrared gas analyzer continuously determines both the absolute $\mathrm{CO}_{2}$ concentration $\left(\left[\mathrm{CO}_{2}\right]\right)$ and the difference between ambient atmospheric $\mathrm{CO}_{2}$ concentration $\left[\mathrm{CO}_{2}\right]$ and the concentration inside the chamber corrected for atmospheric pressure. Air flow rate is expressed as a molar flow rate. The woody tissue $\mathrm{CO}_{2}$ release rates are then calculated as:

$$
R=D\left[\mathrm{CO}_{2}\right] * F / A c
$$

where $R$ is the respiration rate in $\mu \mathrm{mol} \mathrm{CO} \mathrm{CO}^{-2} \mathrm{~s}^{-1}, D\left[\mathrm{CO}_{2}\right]$ is the difference between ambient (reference gas) and chamber (sample gas) $\left[\mathrm{CO}_{2}\right]$ concentration, $F$ is the air flow rate $\left(\mathrm{mol} \mathrm{s}^{-1}\right)$ which passes through the chamber, and $A c$ is the surface area $\left(\mathrm{m}^{2}\right)$ of the enclosed organ segment.

Depending on the diameter of the measured object, $\mathrm{CO}_{2}$ release rates of woody biomass in tropical forests have been related either to surface area (Levy and Jarvis 1998, Chambers et al. 2004), tissue volume (Ryan et al. 1994), or to a combination of both (Meir and Grace 2002). Recently, Cavaleri et al. (2006) found the proper unit of expression of $\mathrm{CO}_{2}$ release by tropical woody tissue is dependent on the position within the tree, with canopy rates related to surface area, but efflux rates in the bottom $2 \mathrm{~m}$ of the canopy related to both volume and surface area. Nevertheless, since the volume of living tissue in stems and woody roots may be differ considerably among tropical trees of different systematic classifications and ages (Meir and Grace 2002, Chambers et al. 2004), we used the surface area of the measured wood sections as a basis for calculation.

Despite evidence that dissolved $\mathrm{CO}_{2}$ is transported in substantial quantities in the xylem sap of certain tree species (Levy and Jarvis 1998, Levy et al. 1999, Horna and Zimmermann 2000, Teskey and McGuire 2002, McGuire and Teskey 2002, Gansert and Burgdorf 2005), we ignored this flux in the current measuring program and interpreted our stem and root efflux data as woody tissue respiration rates. 
Thermal regimes differ greatly along the altitudinal gradient, with little overlap in temperature between the low- and high-elevation sites. Converting respiration rates to a common temperature (e.g., $15-20^{\circ} \mathrm{C}$ ) would yield extrapolated release rates beyond naturally given amplitudes and would result in the comparison of efflux rates at lowest night temperatures at $1050 \mathrm{~m}$ with rates at the upper daytime temperature limit at $3050 \mathrm{~m}$. Therefore, we decided to underpin our comparison of mean stand respiration rates with results of individual regression analyses rather than adjusting apparent efflux rates to a common temperature.

\section{Stand microclimate}

During the 10-day measurement intervals, air temperature and relative air humidity at $2 \mathrm{~m}$ height inside the stands were monitored synchronously using a Rotronic sensor (Rotronic AG, Bassersdorf, Switzerland) connected to the data logger of the ANARESY system (CR 10, Campbell Scientific, Logan, UT). Annual means of air temperature and air humidity for each site were computed from daily climate data from instruments located in each stand $(1.5 \mathrm{~m}$ above ground).

\section{Statistical analysis}

Mean stem respiration rates of individual trees were log-transformed for homogeneity of variances before analysis of variance (ANOVA) testing for significant differences between sites (Scheffé test for unbalanced data sets, $\mathrm{p}<0.05$ ). Root respiration data matched parametric assumptions without transformation.

Carbon dioxide release rates were regressed against tissue surface temperature with the 45 half-hour respiration rates (0100-2300 h) of all measured stems and roots per site. Additionally, we determined the regression coefficients for each individual tree and root segment and for all stems and roots per site. We ran an ANOVA based on the results of the regression analysis of the various stem and root individuals to test for significant differences in respiration rates at $0{ }^{\circ} \mathrm{C}$ (intercept) and responsiveness to temperature (slope) between the three study sites. We used the coefficient of determination $\left(r^{2}\right)$ to quantify the influence of the independent variable (temperature) on the dependent variable $\left(\mathrm{CO}_{2}\right.$ efflux). 


\subsection{Results}

\section{Microclimate}

The study months October to December 2005 were characterized by westerly foehn winds causing relatively dry weather conditions. In this period, 20-30\% less rain fell per month as compared to 2004. As a consequence, relative air humidity $(\mathrm{RH})$ and air temperature $\left(\mathrm{T}_{\mathrm{a}}\right)$ showed considerable variation during the 10-d measurement periods at all study sites (Table 2.2).

Table 2.2. Stand mean air temperature $\left(\mathrm{T}_{\mathrm{a}}\right)$ and relative humidity $(\mathrm{RH})$ during the 10 -daymeasurement campaigns at the study sites at 1050, 1890 and $3050 \mathrm{~m}$ elevation. Overall ranges are given in parenthesis.

\begin{tabular}{|c|c|c|}
\hline Elevation (m) & $\mathrm{T}_{\mathrm{a}}\left({ }^{\circ} \mathrm{C}\right)$ & RH (\%) \\
\hline $1050 \mathrm{~m}$ & $20.8(16.1-30.3)$ & $87.1(39.6-99.9)$ \\
\hline $1890 \mathrm{~m}$ & $17.2(9.5-25.5)$ & $77.6(15.1-99.9)$ \\
\hline $3050 \mathrm{~m}$ & $10.6(4.5-19.9)$ & $91.1(43.4-99.7)$ \\
\hline
\end{tabular}

Woody tissue $\mathrm{CO}_{2}$ efflux along the altitudinal transect

Mean daily $\mathrm{CO}_{2}$ release rates from stems $\left(\mathrm{R}_{\mathrm{S}}\right)$ differed significantly between all sites. Values decreased from $1.38 \mu \mathrm{mol} \mathrm{m} \mathrm{m}^{-2}$ at $1050 \mathrm{~m}$ to $0.21 \mu \mathrm{mol} \mathrm{m}^{-2} \mathrm{~s}^{-1}$ at $3050 \mathrm{~m}$, with an average $\mathrm{R}_{\mathrm{S}}$ of $0.76 \mu \mathrm{mol} \mathrm{m} \mathrm{m}^{-2} \mathrm{~s}^{-1}$ at $1890 \mathrm{~m}$ (Table 2.3). Thus, average stem respiration declined by a factor of 6.6 over an altitudinal span of $2000 \mathrm{~m}$. Parallel to $\mathrm{R}_{\mathrm{S}}$, mean root $\mathrm{CO}_{2}$ efflux $\left(R_{R}\right)$ also tended to decrease along the elevational transect (Table 2.3). Mean $R_{R}$ decreased by $20 \%$ from 1050 to $1890 \mathrm{~m}$ and by $29 \%$ from 1890 to $3050 \mathrm{~m}$, resulting in a $43 \%$ reduction along the whole transect, but differences were not significant.

There was considerable variation in $\mathrm{R}$ among the trees within the three stands (Figure 2.1 - 2.3). The overall range of $R$ values was higher at the lower and mid-elevation stand (two orders of magnitude) than at the upper site (one order of magnitude). Coarse root respiration varied over one order of magnitude within all study sites (data not shown). 

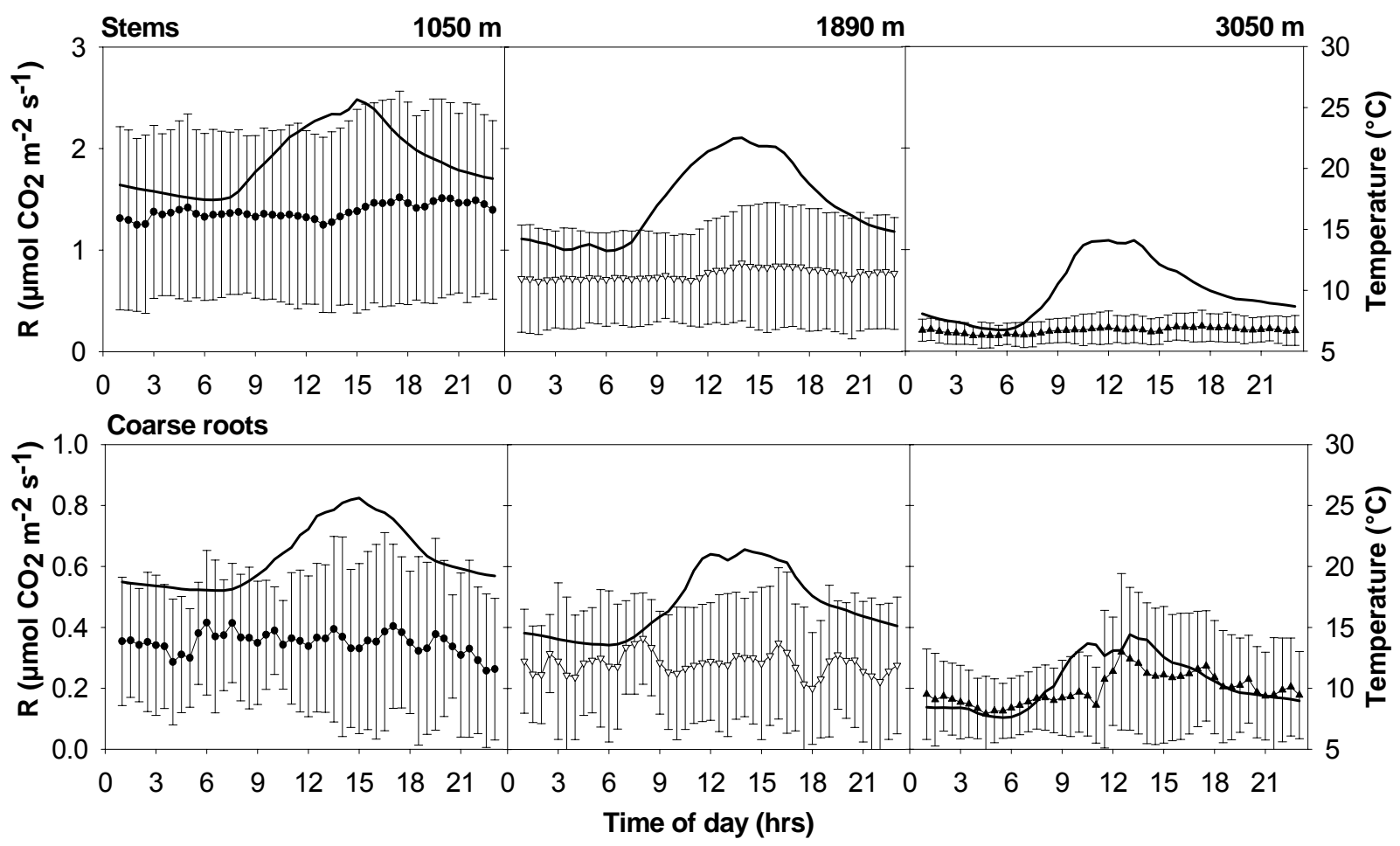

Figure 2.1. Diurnal course of stem and coarse root $(\mathrm{d}: 1-4 \mathrm{~cm})$ respiration together with air temperature (solid line) at the study sites at $1050 \mathrm{~m}$ ( $\mathrm{n}=21$ stems, $\mathrm{n}=8$ roots), $1890 \mathrm{~m}(\mathrm{n}=20$ stems, $n=7$ roots) and $3050 \mathrm{~m}(\mathrm{n}=13$ stems, $\mathrm{n}=4$ roots). Each daily course consists of 45 halfhour measuring points. The 45 half-hour respiration data points are the mean of the diurnal values of 13 to 21 trees or 4 to 8 roots. Error bars equal 1 standard deviation. Air temperature was measured at $2 \mathrm{~m}$ height inside the stands. Note the different scales of the y-axis for stem and root respiration.

\section{Woody tissue $\mathrm{CO}_{2}$ efflux and dependence on temperature}

Mean diurnal $R_{S}$ and $R_{R}$ exhibited little if any change with temperature over the course of the day in all three stands (Figure 2.1). Despite contrasting diurnal temperature regimes at the lower and the upper montane sites, the slopes of the regression analysis of the integrated data sets of stems and coarse roots were similar and remarkably flat (Figure 2.2). ANOVA conducted for intercept and slope of the regression lines of every individual stem $(n=13-21)$ and root segment measured $(n=4-8)$ confirmed that significant differences in temperature responsiveness (coefficient $b$ ) for stems and coarse roots between the three study sites did not exist (Table 2.3). Parallel to the apparent respiration rates at ambient temperature, the mean yaxis intercept (coefficient a) of the individual regression lines significantly decreased for stem respiration between $1050 \mathrm{~m}$ and $3050 \mathrm{~m}$. For coarse root $\mathrm{CO}_{2}$ efflux, the intercept (i.e., the respiration rate at $0{ }^{\circ} \mathrm{C}$ ) also tended to decrease with elevation, but the differences between the sites were not significant. 


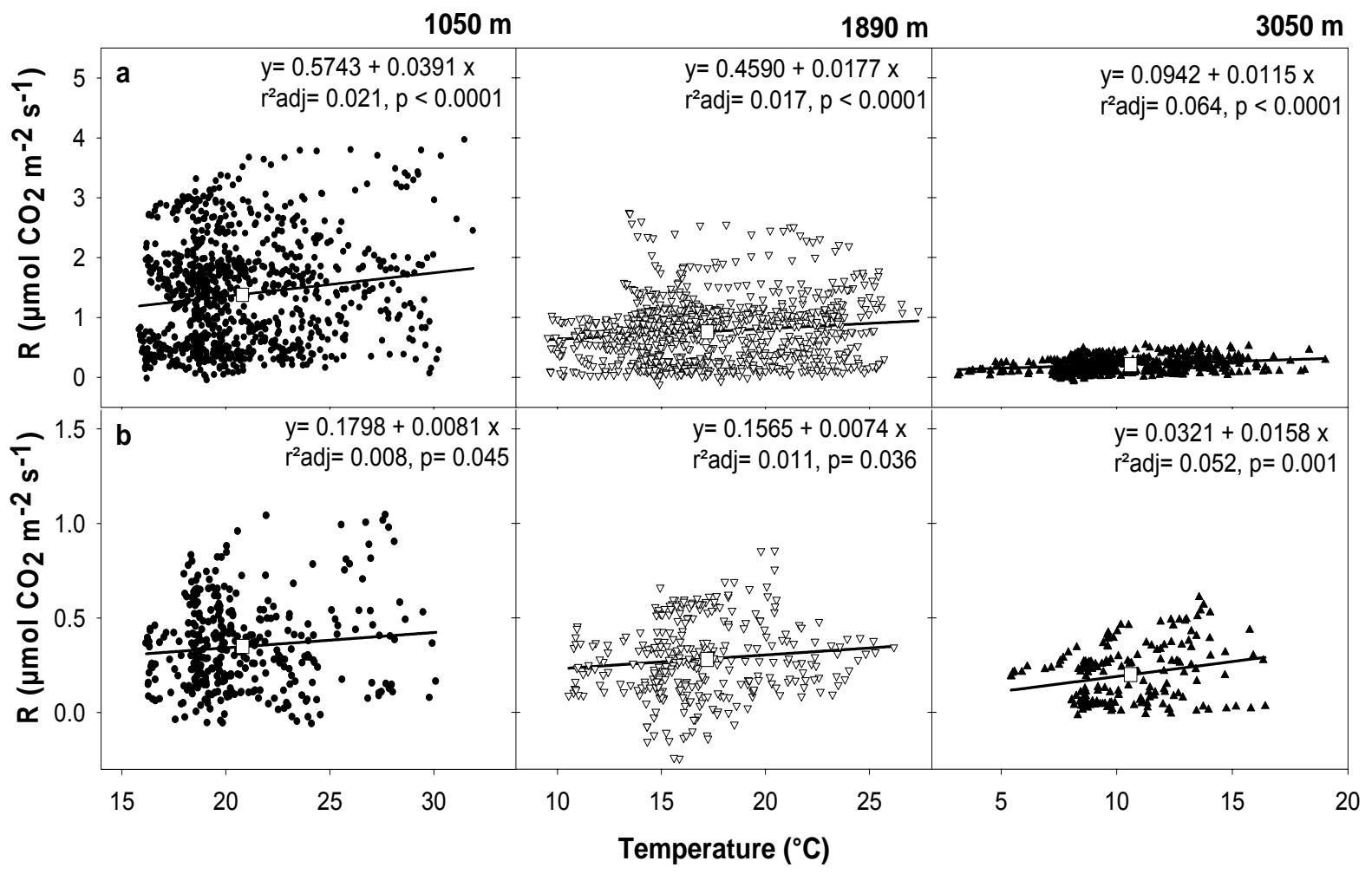

Figure 2.2. Dependence of the $\mathrm{CO}_{2}$ efflux rates (R) of all investigated stems (a) and coarse roots (b) on air temperature at the three study sites $(\bullet=1050 \mathrm{~m}, \nabla=1890 \mathrm{~m}$ and $\boldsymbol{\Delta}=3050 \mathrm{~m}$ a.s.1.). Data points are 45-half-hour values of the 13 - 21 different stems or $4-8$ roots measured during a certain measurement day at ambient temperature. The mean respiration rate at ambient temperature is marked ( $\square$ ) for each stands. Note the different scales of $R$-axis in panels $a$ and $b$.

Although pooling data at stand level resulted in no major differences in temperature responsiveness between sites, regression analysis of individual trees and root segments showed exceptionally high variation in temperature response and respiration rates at $0{ }^{\circ} \mathrm{C}$ (intercept; data not shown) between individuals as well as within sites. Furthermore, we found remarkable discrepancies among individuals in the direction and strength of the temperature dependence of $R_{S}$ and $R_{R}$. Highly significant positive as well as negative relationships were found at $1050 \mathrm{~m}$ and $1890 \mathrm{~m}$, but also no temperature response was detected (Appendix 3a-b). Only in the high-elevation stand $(3050 \mathrm{~m})$ did the regression analysis for individual stems reveal significant positive correlations of $R_{S}$ and temperature in most cases, but no negative relationships were detected (Appendix 3c). Similarly, $R_{R}$ at $3050 \mathrm{~m}$ mainly showed a significant positive relation to temperature. In contrast at the two lower sites, most of the coarse roots did not show any relationship to temperature. The direction of response was not related to taxonomic groups (family) in any of the stands. 


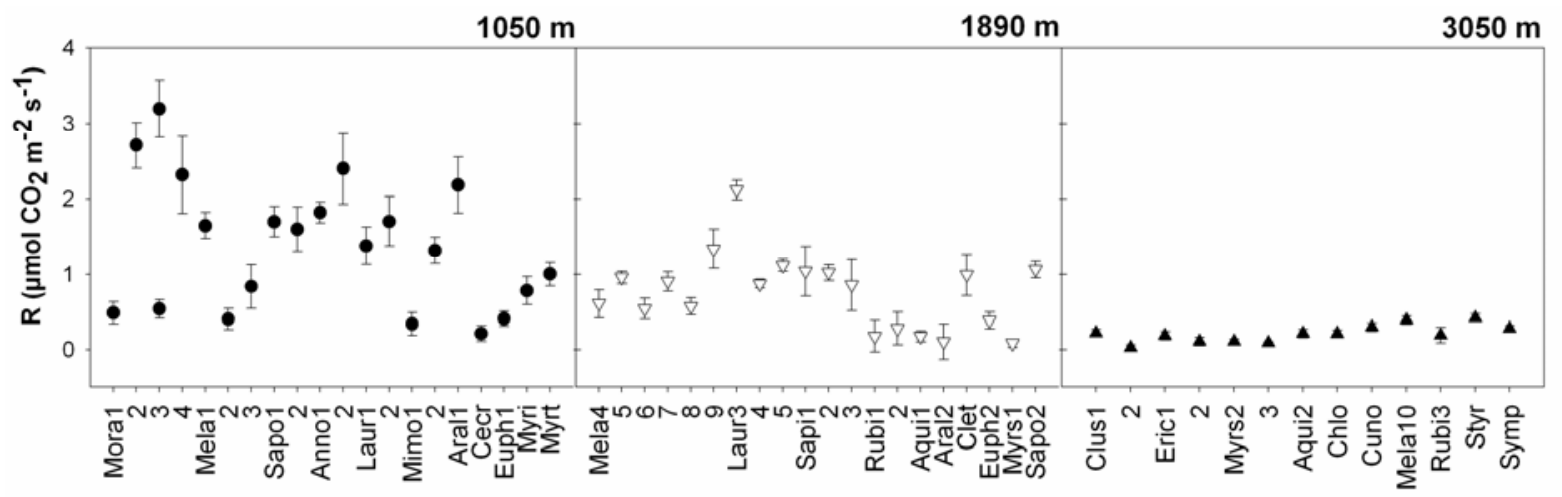

Figure 2.3. Stem $\mathrm{CO}_{2}$ efflux rate $(\mathrm{R})$ of individuals from various families in the stands at 1050, 1890, and $3050 \mathrm{~m}$ elevation. Data are daily means of $\mathrm{R}$ from all measured trees, each consisting of 45 half-hourly values during one day. Error bars equal 1 standard deviation. The families included are those with the greatest number of individuals at the particular site.

Abbreviations: Mora1-4 = Ficus sp; Mela1-2 and 7-9 = Miconia punctata; Mela3 = indet.; Sapo 1 = Chrysophyllum sp; 3-2 = Pouteria cf; Anno1-2 = indet.; Laur1-2 = indet.; Mimo1 = Inga sp; Mimo2 = indet.; Aral1 = Schefflera sp; Cecr = Pourouma $c f ;$ Euph1 = Alchornea sp; Myri = Virola cf; Myrt = indet.; Mela4-6 = Graffenrieda emarginata; Laur3 = Nectandra sp; Laur4 = Endlicheria oreocola; Laur5 = Ocotea aciphylla; Sapi1-3 = Matayba inelegans; Rubi1 = Palicaurea sp; Rubi2 = Ladenbergia of oblongifolia; Aquil = Ilex cf amboroica; Aral2 = Schefflera sp; Clet $=$ Clethra revoluta $c f ;$ Euph2 $=$ Hyeronima morisiana; Myrs1= Myrsine cf; Sapo = Micropholis guyanensis; Clus1 = Clusia sp 1; Clus2 = Clusia sp 2; Eric1 = Cerotostema $c f$; Eric2 = indet.; Myrs2 = Myrsine sp; Mysr3 = indet.; Aqui2 = Ilex weberlingii; Chlo $=$ Hedyosmum sp; Cuno $=$ Weinmannia loxensis; Mela10 = Axinea sp; Rubi3 = Faramea $s p ;$ Styr $=$ Styrax foveolaria $;$ Symp $=$ Symplocos $s p$. 


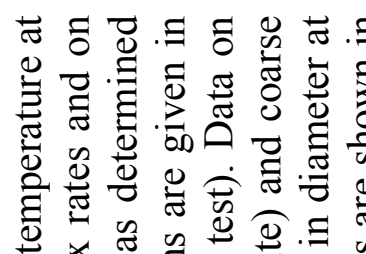

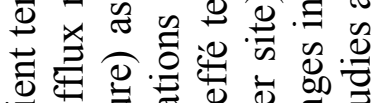

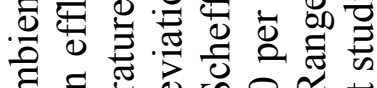
ส స छ

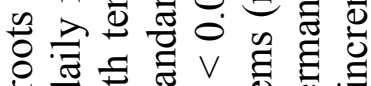

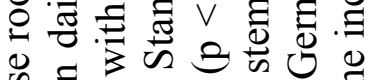

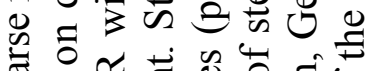

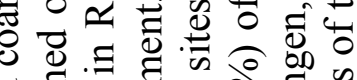

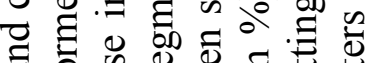
ज

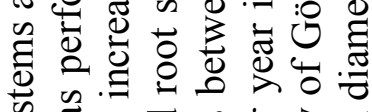

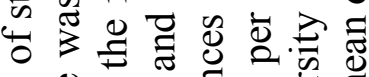
ᄀᄋ山

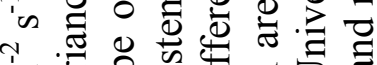
'घ

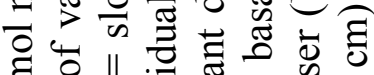

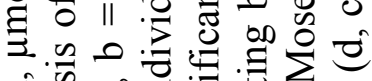
થิ

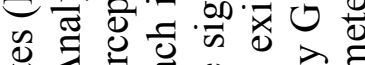

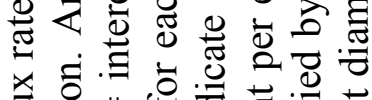

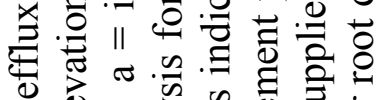

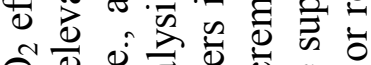
ঠீ 그ㅇㅠㅠ 츰유.

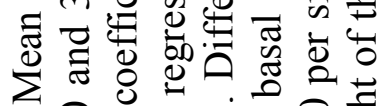
ஸ்

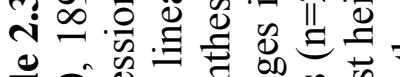

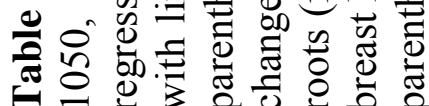

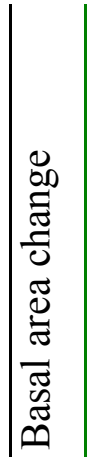

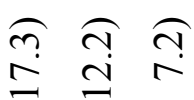

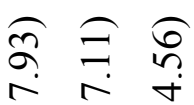

芯芯芯

กิ กิ กิ

จ่

iे ঐे

$\ddot{\ddot{\theta}} \ddot{\ddot{\theta}}$

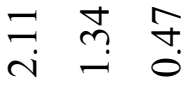

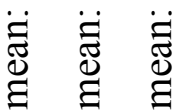

กิ ถุ

तi 00

ते ते in

m $\dot{r}$

تृ تृ

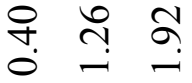

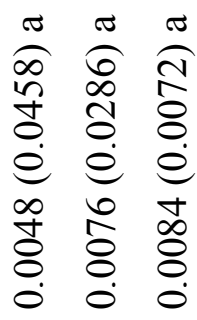

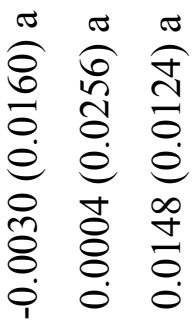

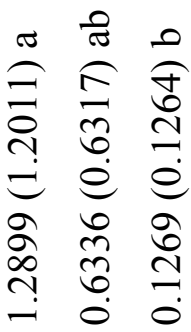

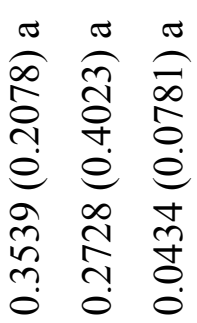

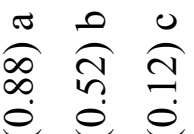

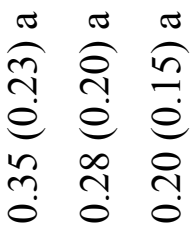

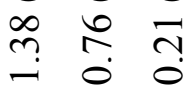

ก 0

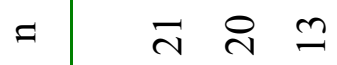

$\infty \sim \nabla$

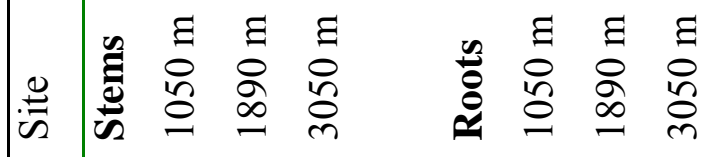




\subsection{Discussion}

Elevational changes of stem and root respiration - evidence for shifts in the relative importance of root versus shoot growth with altitude

To our knowledge, our respiration data are the first reported values for tropical mountain forests. Along our $2000-\mathrm{m}$ elevational transect from 1050 to $3050 \mathrm{~m}$, mean $\mathrm{R}_{\mathrm{S}}$ decreased more than sixfold, whereas $R_{R}$ did not decrease significantly. Because we investigated a large number of stems from different species representing the most abundant families in the three forest stands, this marked decrease in $\mathrm{CO}_{2}$ efflux rates must be a general trend across the altitudinal transect. Moreover, the altitudinal change in $\mathrm{R}_{\mathrm{S}}$ across the transect coincides with a pronounced shift in the aboveground:belowground biomass ratio from 9:1 at $1050 \mathrm{~m}$ to 2:1 at $3050 \mathrm{~m}$ (Moser et al. 2008). Therefore, the apparent belowground shift of respiratory activity may reflect differences in the ratio of growth respiration versus maintenance respiration, with a priority of stem growth at lower elevations and a priority of root growth and root activity at higher elevations.

Dendrometric measurements of stem and coarse woody root growth at our study sites (G. Moser, unpublished data, Table 2.3) revealed a 4.5-fold decrease of relative basal area increment per year for stems from 1050 to $3050 \mathrm{~m}$, counteracted by a 4.8 -fold increase in annual coarse root basal area increment along the altitudinal gradient.

The reduction in stem growth and thus the decrease in stem respiratory activity with increasing elevation is most likely a consequence of decreasing nitrogen availability and reduced photosynthetic gain as a result of decreases in leaf area index and foliar nitrogen concentration at high elevations (Leuschner et al. 2007). The observed coarse root biomass increment along the gradient was paralleled by a pronounced increase in fine root biomass (Moser et al. 2008). Increasing allocations of carbon and nutrients to belowground organs is likely an adaptation to decreasing nutrient availability (Bloom et al. 1985). Soethe et al. (2006) concluded that the large investment in the coarse woody root stock at the highelevation site is an adaptation ensuring tree anchorage on waterlogged and steep slopes at 3050 m elevation.

The lower values of $R_{R}$ relative to $R_{S}$ that were observed at all stand elevations contrast with results commonly reported for coniferous forests. In pine forests, for example, coarse root respiration was found to exceed stem and branch $\mathrm{CO}_{2}$ efflux two- to seven-fold (Pinus radiata: Ryan et al. 1996, Ryan et al. 1997) or even up to ten-fold (Pinus strobus: Vose and Ryan 2002). However, these data come from very different biomes. 
We are unaware of a study on stem or root respiration of trees along altitudinal transects in the Tropics with which our data can be compared.

Mean $R_{S}$ was four times higher than $R_{R}$ at $1050 \mathrm{~m}, 2.7$ times greater at $1890 \mathrm{~m}$, but about equal at $3050 \mathrm{~m}$ : a result of a decrease in $R_{S}$ while $R_{R}$ remained almost constant. The similarity in respiration rates of plants growing across a thermal gradient (Körner and Larcher 1988) has been attributed to acclimation (Amthor 1994) or thermal homeostasis (Larigauderie and Körner 1995). Such adaptation allows plants to meet their energy requirements even when temperatures are low. However, the relative constancy of the coarse root respiratory activity, which we observed with increasing altitude, despite a marked decline in stem $\mathrm{CO}_{2}$ release, is most likely the result of a shift in recourse allocation reflecting the changing environmental conditions. Even though the number of roots measured was quite low, our results closely mirrored the dendrometric studies of Moser et al. (2008) at the same sites, showing an increase in coarse root growth with increasing altitude.

\section{Temperature sensitivity of respiration in tropical mountain forests}

By measuring $\mathrm{CO}_{2}$ efflux in 13 to 21 tree stems and 4 to 8 roots per stand, we demonstrated a substantial within-plot variation in apparent respiratory activity (Figure 2.3). The coefficient of variation in $R_{S}$ remained constant across the gradient, whereas only the overall range in respiratory release decreased with elevation by two orders of magnitude from 1050 to $1890 \mathrm{~m}$ and by one order of magnitude from 1890 to $3050 \mathrm{~m}$.

Similarly, Chambers et al. (2004) reported a variation of two orders of magnitude ( 0.03 to $\left.3.64 \mu \mathrm{mol} \mathrm{m} \mathrm{m}^{-2} \mathrm{~s}^{-1}\right)$ within a stand. However, they focused on ecosystem exchange rates without differentiating between tree families or species. Ryan et al. (1994) found that stem $\mathrm{CO}_{2}$ release rates varied sevenfold between two tree species. In forest stands in central Cameroon and the Brazilian Amazon, stem $\mathrm{CO}_{2}$ release rates from 14 and 13 tree families ranged from 0.2 to $5.2 \mu \mathrm{mol} \mathrm{m}^{-2} \mathrm{~s}^{-1}$ and from 0.1 to $3.3 \mu \mathrm{mol} \mathrm{m} \mathrm{m}^{-1}$, respectively (Meir and Grace 2002). Cavaleri et al. (2006) monitored different plant functional groups in a tropical lowland rain forest in Costa Rica and found substantial differences in the $\mathrm{CO}_{2}$ efflux of stems and branches of dicotyledonous tree species, lianas and palms. The comparable variation among families in stem respiration along our altitudinal transect suggests that there is no decrease in tree functional diversity towards the harsher environment close to the tree line.

Homogeneity among sites in the slopes of the respiratory responses to temperature per site indicated that temperature sensitivity did not differ across elevations. Furthermore, the small slopes suggest that temperature responsiveness is low in the trees of this tropical 
mountain rain forest. By contrast, regressions for individual trees revealed highly variable response patterns within and between sites. The variability in response and the occurrence of inverse temperature responses among coexisting trees could not be explained by taxonomic status (family) or tree size (authors' unpublished observations). Negative respirationtemperature relationships as found at 1050 and $1890 \mathrm{~m}$ elevation may be attributable to climatic effects on xylem sap flow which, in turn, affected the amount of $\mathrm{CO}_{2}$ released through the bark (Gansert and Burgdorf 2005). It is also possible that the exceptionally dry and hot weather during the measurement periods induced changes in respiratory activity. The capacity to acclimate to short- (hours) or medium-term (days) changes, or both, in temperature can vary greatly among individual plant species (Larigauderie and Körner 1995, Atkin et al. 2005). Additionally, plants or organs able to acclimate rapidly by short-term weather fluctuations may even show continuously changing temperature responsiveness as found by Atkin et al. (2000) for leaf dark respiration of Eucalyptus pauciflora Sieb. ex Spreng..

Based on absolute values, the mean slopes of the stem and coarse root response to temperature were steeper at the higher elevation site, indicating a more pronounced thermal sensitivity of the cold-grown plants. Higher $\mathrm{Q}_{10}$ values in plants grown in cold environments compared with warm-grown ones were found by Tjoelker et al. (2001), whereas Larigauderie and Körner (1995) found that the variability of leaf $Q_{10}$ was unrelated to plant origin. Atkin et al. (2005) concluded that a systematic variation in $\mathrm{Q}_{10}$ values does not exist and that differences among contrasting biomes are relative and thus do not reflect an inherent variable temperature responsiveness of characteristic plant species. However, our results showed that the mean temperature sensitivity of stems and coarse roots was similar among the contrasting thermal environments along the gradient, whereas the analyses of individual plant responses showed that large differences in temperature responsiveness exist within the three study sites.

Given the homogeneity of mean slopes across the differing growth environments, any differences in $\mathrm{CO}_{2}$ release rates across our gradient resulted from differences in the y-axis intercept or respiration rate at $0{ }^{\circ} \mathrm{C}$. Removing temperature as a confounding factor still yielded a marked decrease in stem $\mathrm{CO}_{2}$ efflux from 1050 to $3050 \mathrm{~m}$, indicating that temperature might not be the primary influencing factor as underpinned by the low temperature sensitivity found along the altitudinal gradient. 


\section{Conclusions}

Our respiration measurements along a tropical mountain transect indicate a shift from high respiratory activity of stems compared with coarse roots at lower elevation $(1050 \mathrm{~m})$ to an apparent equivalence of stem and coarse root $\mathrm{CO}_{2}$ efflux rates at $3050 \mathrm{~m}$. The observed decrease in the ratio of stem to root efflux rates with altitude may be explained by the substantial decrease in stem growth, while coarse root growth increased with increasing elevation. We found that responses of $\mathrm{CO}_{2}$ release rates of woody tissue to changes in temperature differed greatly between study sites, as well as among species and plant organs, with the underlying mechanisms remaining unclear. The remarkable variation in respiratory activity and, most importantly, in temperature response of respiration suggests that predictions at the community level or even estimates for entire ecosystems on the basis of few point measurements of selected plant species must be interpreted cautiously. Because there was great variation in acclimation pattern among plants and between sites, questions about the response of plant community $\mathrm{CO}_{2}$ efflux to climate change should principally be answered at the community level (Larigauderie and Körner 1995).

\section{Acknowledgements}

For helpful advice and technical support during the field measurements we thank Reiner Zimmermann and Manfred Küppers (University of Hohenheim). We thank Florian Werner (University of Goettingen) for invaluable contributions on early versions of the manuscript. We are grateful to Gerald Moser (University of Goettingen) for contributing data on tree growth and general stand characteristics. We also thank our field assistants Tati, Polivio, Abraham and others for their patient and careful help in carrying the heavy equipment. We gratefully acknowledge the financial support obtained from DFG (German Science Foundation) through a grant in the Research Unit 402 (Functionality in a Tropical Mountain Rainforest, subproject B6). We thank the Ministerio del Ambiente Loja-Zamora for the research permit, and the Fundación Científica San Francisco (Nature and Culture International) for the ongoing support at Estación Científica San Francisco. 


\subsection{References}

Amthor JS (1994) Plant respiratory responses to the environment and their effects on the carbon balance. In: Plant-environment interactions. (ed. Wilkinson RE). Marcel Dekker, New York, pp. 501-554.

Amthor JS (2000) The McCree-de Wit-Penning de Vries-Thornley respiration paradigms: 30 years later. Annals of Botany 86, 1-20.

Atkin OK, Holly C, Ball MC (2000) Acclimation of snow gum (Eucalyptus pauciflora) leaf respiration to seasonal and diurnal variations in temperature: the importance of changes in capacity and temperature sensitivity of respiration. Plant Cell and Environment 23, 15-26.

Atkin OK, Bruhn D, Hurry VM, Tjoelker MG (2005) The hot and the cold: unravelling the variable response of plant respiration to temperature. Functional Plant Biology 32, 87105.

Bloom AJ, Chapin FS III, Mooney HA (1985) Resource limitation in plants - an economic analogy. Annual Review of Ecological Systematic 16, 363-392.

Cavaleri MA, Oberbauer SF, Ryan MG (2006) Wood $\mathrm{CO}_{2}$ efflux in a primary tropical rain forest. Global Change Biology 12, 2442-2458.

Cavieres AL, Rada F, Azócar A, García-Núnez C, Cabrera HM (2000) Gas exchange and low temperature resistance in two tropical high mountain tree species from the Venezuelan Andes. Acta Oecologia 21, 203-211.

Chambers JQ, Tribuzy ES, Toledo LC, Crispim BF, Higuchi N, Dos Santos J, Araújo AC, Kruijt B, Nobre AS, Trumbore SE (2004) Respiration from a tropical forest ecosystem: Partitioning of sources and low carbon use efficiency. Ecological Applications 14, 72-88.

Emck P (2007) A climatology of South Ecuador. PhD Thesis, University of Erlangen, Germany, pp. 272.

Gansert D, Burkdorf M (2005) Effects of xylem sap flow on carbon dioxide efflux from stems of birch (Betula pendula Roth). Flora 200, 444-455.

Horna V, Zimmermann R (2000) Carbon release from stems and branches of two tree species with contrasting phenology in a seasonally flooded Amazon forest. In: Neotropical Ecosystems, Proceedings of the German-Brazilian Workshop. (eds. Lieberei R, Bianchi H-K, Boehm V, Reisdorff C). GKSS-Geesthacht, Hamburg, pp. 579-587.

Körner C, Larcher W (1988) Plant life in cold environments. In: Plants and Temperature. Symposium of the Society of Experimental Biology Vol. 42. (eds. Long SP, Woodward FI). The Company of Biologists, Cambridge, pp. 25-57. 
Larigauderie A, Körner C (1995) Acclimation of dark leaf respiration in alpine and lowland plant species. Annals of Botany 76, 245-252.

Lavigne MB, Franklin SE, Hunt ER Jr. (1996) Estimating stem maintenance respiration rates of dissimilar balsam fir stands. Tree Physiology 16, 687-695.

Leuschner C, Moser G, Bertsch C, Röderstein M, Hertel D (2007) Large altitudinal increase in the tree root/shoot ratio in tropical mountain forests of Ecuador. Basic and Applied Ecology 8, 219-230.

Levy PE, Jarvis PG (1998) Stem $\mathrm{CO}_{2}$ fluxes in two Sahelian shrub species (Guiera sengalensis and Combretum micranthum). Functional Ecology 12, 107-116.

Levy PE, Meir P, Allen SJ, Jarvis PG (1999) The effect of aqueous transport of $\mathrm{CO}_{2}$ in xylem sap on gas exchange of woody plants. Tree Physiology 19, 53-59.

McGuire MA, Teskey RO (2002) Microelectrode technique for in situ measurement of carbon dioxide concentrations in xylem sap of trees. Tree Physiology 22, 807-811.

Meir P, Grace J (2002) Scaling relationship for woody tissue respiration in two tropical rain forests. Plant, Cell and Environment 25, 963-973.

Moser G (2008) Elevation effects on key processes of carbon cycling in south Ecuadorian mountain forests. PhD Thesis, University of Göttingen, Germany, pp. 125.

Moser G, Roederstein M, Soethe N, Hertel D, Leuschner C (2008) Altitudinal changes in stand structure and biomass allocation of tropical mountain forests in relation to microclimate and soil chemistry: a transect study in Ecuador and a neotropical metaanalysis. In: Gradients in tropical mountain ecosystems of Ecuador. (eds. Beck E, J Bendix, I Kottke, F Makeschin, R Mosandl). Springer Verlag, Berlin Heidelberg, Ecological Studies 198, 229-242.

Müller D, J Nielson (1965) Production brute, pertes par respiration e production nette dans la foret ombrophile tropicale. Fortsliche Forsogsvaes Danmark 29, 69-160.

Röderstein M, Hertel D, Leuschner C (2005) Above- and below-ground litter production in three tropical mountain forests (South Ecuador). Journal of Tropical Ecology 21, 483-492

Ryan MG, Hubbard RM, Clark DA, Sanford RL Jr (1994) Woody-tissue respiration of Simarouba amara and Minquartia guinensis, two wet forest trees with different growth habits. Oecologia 100, 213-220.

Ryan MG, Gower ST, Hubbard RM, Waring RH, Gholz HL, Cropper WP, Running SW, (1995) Woody tissue maintenance respiration of four conifers in contrasting climates. Oecologia 101, 133-140. 
Ryan MG, Hubbard RM, Pongracic S, Raison RJ, McMurtie RE (1996) Foliage, fine-root, woody-tissue and stand respiration in Pinus radiata in relation to nitrogen status. Tree Physiology 16, 333-343.

Ryan MG, Lavigne MB, Gower ST (1997) Annual carbon costs of autotrophic respiration in boreal forest ecosystems in relation to species and climate. Journal of Geophysical Research 102, 28, 871-883.

Schrumpf M, Guggenberger G, Schubert C, Valarezo C, Zech W (2001) Tropical montane rain forest soils - development and nutrient status along an altitudinal gradient in the south Ecuadorian Andes. Die Erde 132, 43-59.

Soethe N, Lehmann J, Engels C (2006) The vertical pattern of rooting and nutrient uptake at different altitudes of a south Ecuadorian montane forest. Plan and Soil 286, 287-299.

Sprugel DG, Benecke U (1991) Measuring woody-tissue respiration and photosynthesis. In: Techniques and approaches in forest tree ecophysiology (eds. Lassoie JP, Hinckley T) CRC-Press Inc, Boston, pp. 329-355.

Teskey RO, McGuire MA (2002) Carbon dioxide transport in xylem causes errors in estimation of rates of respiration in stems and branches of trees. Plant Cell and Environment 25, 1571-1577.

Tjoelker MG, Oleksyn J, Reich PB (2001) Modelling respiration of vegetation: evidence for a general temperature-dependent $\mathrm{Q}_{10}$. Global Change Biology 7, 223-230.

Trumbore S (2006) Carbon respired by terrestrial ecosystems - recent progress and challenges. Global Change Biology 12, 141-153.

Voss JM, Ryan MG (2002) Seasonal respiration of foliage, fine roots, and woody tissue in relation to growth, tissue N, and photosynthesis. Global Change Biology, 8, 182-193.

Whitmore TC (1984) Tropical rainforests of the Far East. 2nd Edn. Clarendon Press Oxford, pp. 351.

Yoda K (1967) Comparative ecological studies on three main types of forest vegetation in Thailand. III. Community Respiration. Nature Life SE Asia 5, 83-148. 


\section{Chapter}

3

DIVERGING TEMPERATURE RESPONSE OF

Tree Stem $\mathrm{CO}_{2}$ EFfluX to Dry And Wet SEAson CONDitions In A TROPICAL MONTANE MOIST FoREST

AlEXANDRA ZaCh, Viviana HoRnA AND Christoph LEUSCHNER

SUBMitTED to: TREES - StRUCTURE AND FUNCTION 


\subsection{Abstract}

It is commonly presumed that plant respiratory $\mathrm{CO}_{2}$ release increases with increasing temperature. However, we report on very contrasting stem $\mathrm{CO}_{2}$ release $\left(\mathrm{R}_{\mathrm{S}}\right)$-temperature relationships of trees in a species-rich tropical montane forest of southern Ecuador under dry and wet season conditions. Rates of $\mathrm{R}_{\mathrm{S}}$ were low and completely uncoupled from the dial temperature regime during the humid season. In contrast, during the dry season, $\mathrm{R}_{\mathrm{S}}$ was generally higher and temperature sensitivity of $R_{S}$ differed greatly in degree and even in the direction of response, indicating that temperature might not be the only determinant of $R_{S}$. In order to explain the heterogeneity of $R_{S}$, we related $R_{S}$ to vapour pressure deficit, wind speed and solar radiation as important abiotic drivers influencing transpiration and photosynthesis. Stepwise multiple regression analyses with these meteorological predictors were either biased by high collinearity of the independent variables or could not enhance the ability to explain the variability of $R_{S}$. We assume maintenance respiration to dominate under humid conditions unfavourable for energy acquisition of the tree, thus explaining the pronounced uncoupling of $\mathrm{R}_{\mathrm{S}}$ from atmospheric parameters. In contrast, the drier and hotter climate of the dry season seems to favour $R_{S}$ via enhanced assimilatory substrate delivery and stem respiratory activity as well as elevated xylem sap $\mathrm{CO}_{2}$ imports with increased transpiration. In addition, tree individual differences in the temperature responses of $\mathrm{R}_{\mathrm{S}}$ may mirror diverging climatic adaptations of co-existing moist forest tree species which have their distribution centre either at higher or lower elevations.

Keywords: climatic adaptation, Ecuador, stem respiration, temperature sensitivity of respiration, tree species richness 


\subsection{Introduction}

Temperature has long been identified as the most important abiotic factor influencing plant respiratory activity due to its well known affect on enzymatic reactions (e.g. Amthor 1989). A strong relationship between temperature and plant tissue respiration has been exhaustively proved and verified under controlled conditions (e.g. Maier et al. 1998, Tjoelker et al. 1999, Atkin et al. 2000, Tjoelker et al. 2001, Loveys et al. 2003, Armstrong et al. 2006, Atkin et al. 2006, Atkin et al. 2007). However, in the field, a consistent relationship is often not found (e.g. Edwards and McLaughlin 1978, Negisi 1982, Lavigne 1987, Gunderson et al. 2000, Teskey and McGuire 2002). Especially woody tissue respiration is reported not to be exclusively related to temperature since other sources of $\mathrm{CO}_{2}$ than the respiratory activity of living wood cells (inner bark, cambium, xylem parenchyma) alone can influence the apparent amount of $\mathrm{CO}_{2}$ escaping through the bark. Imports of dissolved $\mathrm{CO}_{2}$ via the transpiration stream can add substantial amounts to the stem internal carbon dioxide. The quantitative contribution of the different sources to the internal flux of $\mathrm{CO}_{2}$ was found to vary considerably on a seasonal as well as daily basis. Consequently, stem internal $\mathrm{CO}_{2}$ concentrations can constantly fluctuate, which in turn can affect the amount of $\mathrm{CO}_{2}$ diffusing out of the bark (e.g. McGuire and Teskey 2004, Teskey et al. 2008, Saveyn et al. 2008ab).

Stem respiration usually depends on substrate availability, the demand for energy equivalents and the enzymatic activity (Amthor 1995, Lambers et al. 1998, Pruyn et al. 2002, 2005, Atkin et al. 2005). However, it is still barely understood how stem $\mathrm{CO}_{2}$ release $\left(\mathrm{R}_{\mathrm{S}}\right)$ is finally controlled and how internally circulating $\mathrm{CO}_{2}$ is influencing the apparent efflux. High rates of $R_{S}$ coincided with high xylem sap fluxes (Levy and Jarvis 1998, Levy et al. 1999, Horna and Zimmermann 2000). Other studies reported a negative correlation between xylem flux and radial $\mathrm{CO}_{2}$ efflux (Negisi 1979, Edwards and Hanson 1996, Teskey and McGuire 2002, Gansert and Burgdorf 2005, Teskey and McGuire 2007). All these studies suggested that $\mathrm{R}_{\mathrm{S}}$ might be linked to canopy water use. However, removing the foliage had little effect on the dial pattern of $R_{S}$ in an experiment of Maier and Clinton (2006). No relationship between sap flow and $R_{S}$ was found by Ceschia (2001), Carey et al. (1996) and Edwards and Wullschleger (2000). Studies of xylem sap flow were mainly conducted on coniferous (Carey et al. 1996, Maier and Clinton 2006) or deciduous (Edwards and Hanson 1996, Ceschia 2001, Gansert and Burgdorf 2005, Teskey and McGuire 2007) tree species of temperate climates. Results of one single tree (Ceschia et al. 2006, Gansert and Burgdorf 2005, McGuire and Teskey 2002, Saveyn et al. 2008a) or of few individuals of the same species (McGuire and 
Teskey 2007, Maier and Clinton 2006, Saveyn et al. 2008b) have been used to generalize trends in the influence of internal $\mathrm{CO}_{2}$ on apparent $\mathrm{CO}_{2}$ efflux rates.

However, on the ecosystem level the picture gets more complicated due to the fact that co-occurring plants are responding individualistically to their specific environment and probably even more so to shifts in the environmental setting (Larigauderie and Körner 1995, Arnone and Körner 1997, Amthor 1989, Oren and Pataki 2001, Reich et al. 2003, Atkin et al. 2005, Kerkhoff et al. 2005, Enquist et al. 2007). A better understanding of the variability in $\mathrm{R}_{\mathrm{S}}$ among different individuals in a population, different species in a stand, and different patches of the forest is therefore crucial to predict changes in the carbon dioxide exchange between tree wood and the atmosphere, in particular in highly diverse tropical forests (Kerkhoff et al. 2005, Enquist et al. 2007).

In this paper, we report on in situ-measurements of the diurnal rates of $R_{S}$ of representative tree species in a tropical montane moist forest in southern Ecuador during two hydrologically contrasting seasons of the year. Under the prevailing moist conditions, mean annual temperature is relatively low and diurnal temperature amplitudes are small. In contrast, the short dry season climate is characterized by exceptionally high day-time and low nighttime temperatures. Trees of this ecosystem have to cope with constantly low temperatures, compared to lowland forests, while being exposed to unpredictable short-term microclimatic shifts. The objectives of this study were (i) to analyse the temperature-response of $R_{S}$ of adapted moist forest tree species during two contrasting seasons, i.e sunny-dry versus cloudymoist weather conditions, and (ii) to compare patterns of $R_{S}$ of eight co-existing tree species from seven families for quantifying variability between trees. Linear regression analyses and stepwise multiple regressions with selected meteorological factors (vapour pressure deficit, wind speed, solar radiation) were used to take account of abiotic drivers controlling transpiration and photosynthesis, which may affect $\mathrm{R}_{\mathrm{S}}$ under contrasting climatic conditions. We hypothesize that plant inherent factors and external variables apart from temperature are playing an important role in determining the apparent $\mathrm{R}_{\mathrm{S}}$ at the level of individual trees. 


\subsection{Materials \& Methods}

\section{Study area and tree selection}

The study was conducted in the Reserva San Francisco (RSF) adjacent to the Podocarpus National Park (PNP) on the eastern slopes of the southern Ecuadorian Andes. The study site (S $\left.03^{\circ} 58^{\prime} 345^{\prime \prime} / \mathrm{W} 79^{\circ} 04^{\prime} 648^{\prime \prime}\right)$ is located at $1890 \mathrm{~m}$ elevation and covered by a species-rich lower montane forest of about $12 \mathrm{~m}$ in height. Forest structure and species composition are described in more detail by Röderstein et al. (2005) and Leuschner et al. (2007). The soils of the region developed from metamorphic shale, quartzite and sandstone bedrock; they are characterized by low fertility (Schrumpf et al. 2001).

Within the stand we selected 20 mature canopy trees representing abundant families and comprising a broad range of stem diameters. Further details on tree selection are given in Zach et al. (2008) (see Chapter 2 and Appendix 1).

For the exemplary study on the impacts of the dry season conditions on stem respiratory activity we restricted analysis to 10 out of the 20 mature canopy trees sampled (Table 3.1). These 10 trees had been measured during a pronounced dry season period characterized by high ambient temperature, high vapour pressure deficits (D) and declining soil water availability (Figure 3.1). The remainder 10 trees were measured one week earlier, when some rain fell, which did not allow for an appropriate comparison of wet and dry season respiratory patterns. The tree selection comprised canopy tree species of 7 families (Table 3.1). Most of the tree species were represented by only one individual, except Miconia punctata and Matayba inelegans of which each two individuals of similar size were sampled (Table 3.1). Trees were equipped with dendrometer bands for increment measurements.

Rates of stem $\mathrm{CO}_{2}$ release $\left(\mathrm{R}_{\mathrm{S}}\right)$ of the selected tree individuals were measured during four days in the dry period in November 2005(DOY 324-327; Figure 3.1) and four days during the humid season in April 2006 (DOY 117-120). For each tree we conducted one 24hrs-course of $R_{S}$. Diurnal values were averaged to calculate the mean daily rate of $R_{S}$ of each tree (Table 3.1), while the entire dataset was used for regression analysis (Table 3.2, Figure 3.2). $\mathrm{R}_{\mathrm{S}}$ was monitored at breast height $(1.3 \mathrm{~m})$ using the mobile 6-chamber respiration system ANARESY 2 (Walz, Effeltrich, Germany) and an integrated LI-7000 infrared gas analyzer for $\mathrm{CO}_{2}$ and $\mathrm{H}_{2} \mathrm{O}$ (Li-Cor, Inc., Lincoln, NE, USA) running in differential mode. Details of the technical equipment are provided in Zach et al. (2008; Chapter 2). 
营峲

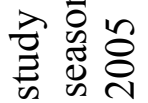

局

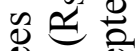

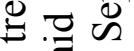

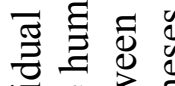

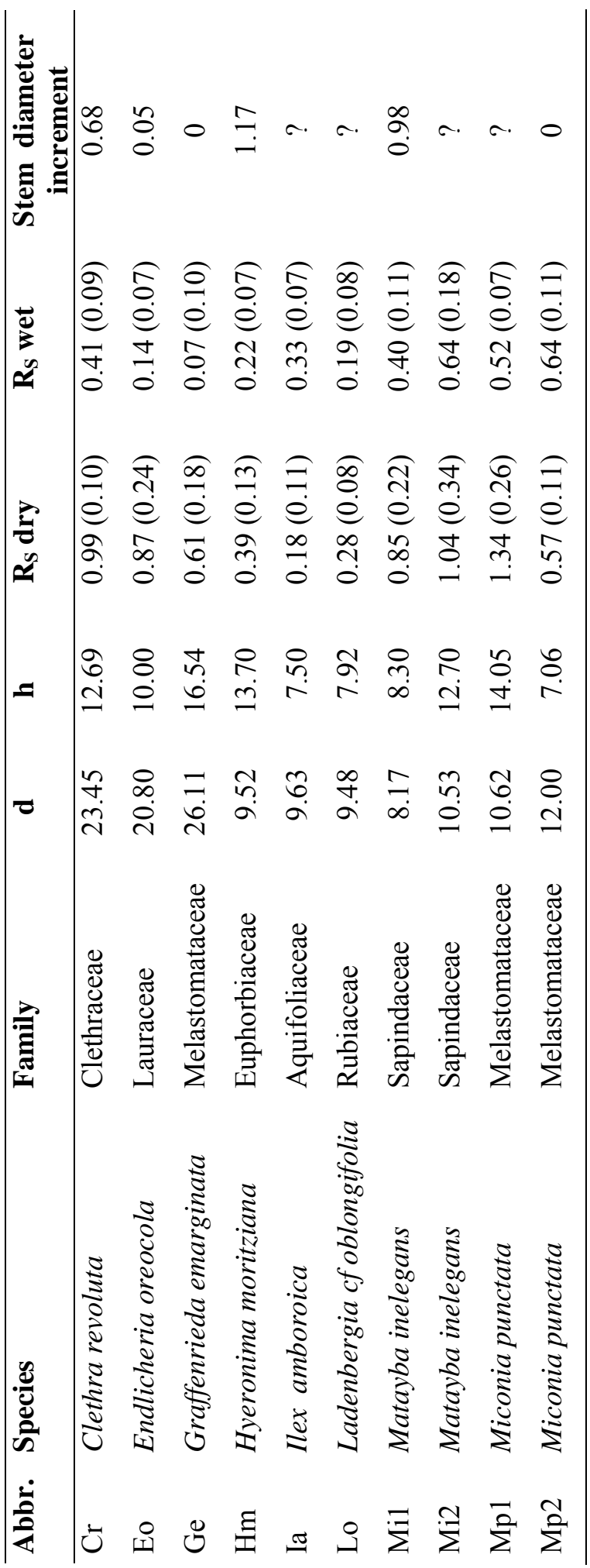

엉요

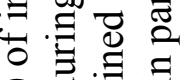

的氖司

ก

O용

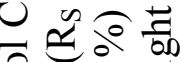

政

$\exists=5$

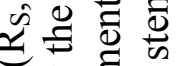

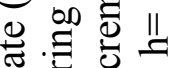

完吉导

跣

$\stackrel{\Xi}{\square}$

กิ

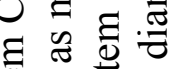

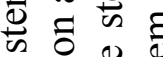

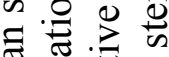

这

$\sum \approx$

मे छ

음

त्त्र 
Air temperature $\left(\mathrm{T}_{\mathrm{A}}\right)$ and relative air humidity at $2 \mathrm{~m}$ height inside the stand were monitored using a Rotronic sensor (Rotronic AG, Bassersdorf, Switzerland) connected to the data logger of the ANARESY system (CR 10, Campbell Scientific, Logan, UT, USA). Thermocouples (diameter: $3 \mathrm{~mm}$, length: $20 \mathrm{~mm}$, Siemens, Munich, Germany) for tissue temperature $\left(\mathrm{T}_{\mathrm{T}}\right)$ measurement were installed at breast height (depth: $10 \mathrm{~mm}$ ) at two arbitrarily chosen tree stems (DBH: 15 and $20 \mathrm{~cm}$ ) in July 2006 for continuous measurements. We used data from July/August 2006 and November 2006 to establish relationships between the continuously recorded air temperature and tissue temperature:
(1) wet season: $\mathrm{T}_{\mathrm{T}}=19.74 *\left(1-\exp ^{\left.\left(-0.0888 \mathrm{~T}_{\mathrm{A}}\right)^{\prime}\right)}\right.$
$\left(\operatorname{adj~} \mathrm{r}^{2}=0.83, \mathrm{p}<0.0001\right)$
(2) dry season: $\mathrm{T}_{\mathrm{T}}=23.13 *\left(1-\exp ^{\left(-0.0736 \mathrm{~T}_{\mathrm{A}}{ }^{\prime}\right)}\right.$
$\left(\operatorname{adj} \mathrm{r}^{2}=0.87, \mathrm{p}<0.0001\right)$

where $T_{A}$ is the air temperature measured inside the stand. These equations were used to calculate tissue temperature from air temperature in all periods where tissue temperature was not recorded.

\section{Climatic conditions of the measurement periods}

In general, the climate of the study area is humid throughout the year. However, an extremely wet period (April to July) is followed by several months with less frequent rainfall (September to December) (Bendix et al. 2006). Mean annual precipitation at 1960m a.s.l. is ca. $2200 \mathrm{~mm}$ (Emck 2007), annual mean air temperature is $15.7^{\circ} \mathrm{C}$ and relative humidity 90.7\% (Moser et al. 2008).

During November 2005, foehn winds caused an exceptionally dry and sunny period throughout the study area. Fires occurred frequently throughout the wider region during this period. Only $90 \mathrm{~mm}$ of rainfall were recorded in November, which fell during the first two weeks (M. Richter, unpublished data). When we started respiration measurements end of November, the rainless period had already lasted for seven days. The lack of rainfall resulted in a substantial decrease of air humidity and an increase of daily temperature amplitudes compared to the wet season conditions. Vapour pressure deficit (D) continuously increased during the three consecutive measurement days in November (Figure 3.1, data recorded by M. Richter at a nearby climate station, unpublished). Substantially higher wind speeds were recorded during the dry period compared to the humid days (Figure 3.1). 
The average soil water matric potential $\left(\psi_{\mathrm{S}}\right)$ as measured in adjacent forest sites at $2000 \mathrm{~m}$ progressively decreased during the measurement days in November from $-0.15( \pm$ $0.13)$ to $-0.24( \pm 0.12) \mathrm{MPa}$ at $15 \mathrm{~cm}$ depth and from $-0.10( \pm 0.09)$ to $-0.19( \pm 0.12) \mathrm{MPa}$ at $30 \mathrm{~cm}$ (S. Engelhardt, unpublished data). Minimum values of $-0.60 \mathrm{MPa}(15 \mathrm{~cm})$ and -0.49 $\mathrm{MPa}(30 \mathrm{~cm})$ were recorded at the end of the measurements (Figure 3.1).

The measurement campaign in the wet period was conducted at the beginning of the humid season in April 2006. During this month precipitation was frequent. Low diurnal temperature amplitudes and a moderate vapour pressure deficit were characteristic for this season (Figure 3.1). Data of the soil matric potential were only available for the last two measurement days. This data indicates that soil moisture exceeded field capacity with potential values greater than -0.1 MPa (S. Engelhardt, unpublished data).

\section{Data treatment}

The stem $\mathrm{CO}_{2}$ release rates $\left(\mathrm{R}_{\mathrm{S}}\right)$ were calculated as:

$$
R_{S}=D\left[\mathrm{CO}_{2}\right] * F / A C
$$

where $R_{S}$ is the $\mathrm{CO}_{2}$ release rate $\left(\mu \mathrm{mol} \mathrm{CO}_{2} \mathrm{~m}^{-2} \mathrm{~s}^{-1}\right), D\left[\mathrm{CO}_{2}\right]$ is the difference between ambient (reference gas) and chamber (sample gas) $\mathrm{CO}_{2}$ concentration, $F$ is the molar air flow rate $\left(\mathrm{mol} \mathrm{s}{ }^{-1}\right)$ which passes through the chamber, and $A c$ is the surface area $\left(\mathrm{m}^{2}\right)$ of the enclosed stem segment. In an earlier study (Zach et al. 2008, Chapter 2) we found better agreement when relating the apparent $\mathrm{CO}_{2}$ efflux rates to stem surface area than to volume.

We chose the slope of the regression curve of $R_{S}$ on temperature as a measure of the temperature sensitivity of respiration instead of the commonly used $\mathrm{Q}_{10}$ value. The $\mathrm{Q}_{10}$ of respiration (i.e., the factor expressing the proportional change in respiratory $\mathrm{CO}_{2}$ release per $10{ }^{\circ} \mathrm{C}$ rise in temperature) basically compares the $\mathrm{CO}_{2}$ efflux rate at a given temperature to that at a $10{ }^{\circ} \mathrm{C}$ lower temperature (Atkin et al. 2005). Plant respiration is a process influenced by various environmental factors. Consequently, neither the Arrhenius nor the $\mathrm{Q}_{10}$ model has been found to adequately describe the observed temperature response of respiration under field conditions. For that reason, reported measures of temperature responsiveness have to be treated with caution (Tjoelker et al. 2001, Atkin and Tjoelker 2003). In addition, there is evidence that the respiratory response to temperature is neither constant nor necessarily exponential (Atkin et al. 2000, Atkin and Tjoelker 2003, Atkin et al. 2005). Instead of focussing on two single data points on the temperature axis, we used the entire diurnal dataset of $\mathrm{R}_{\mathrm{S}}$ for analysing the temperature dependency of $\mathrm{R}_{\mathrm{S}}$. 
One important source of variation in diurnal and seasonal $R_{S}$ is the internal transport of dissolved $\mathrm{CO}_{2}$ in the transpiration stream influencing the apparent $\mathrm{CO}_{2}$ release through the bark (Edwards and Hanson 1996, Levy and Jarvis 1998, Teskey and McGuire 2002, Gansert and Burgdorf 2005, Teskey and McGuire 2007). Because we did not measure xylem sap flow directly, we used D, wind speed and solar radiation as the main determinants of transpiration in our regression analysis in the attempt to explain the large heterogeneity of $\mathrm{R}_{\mathrm{S}}$.

By means of linear regression we analyzed the temperature responsiveness of $R_{S}$ for each tree individual during the dry and humid season. For each tree, rates of $\mathrm{R}_{\mathrm{S}}$ were plotted against the respective courses of $\mathrm{T}_{\mathrm{T}}$ and $\mathrm{T}_{\mathrm{A}}$ using either the diurnal dataset, or by considering only day-time or night-time values. To improve the explanatory power of the regression equation, we conducted linear regression analyses with the three additional meteorological predictor variables ( $\mathrm{D}$, wind speed, solar radiation). Using coefficient of determination $\left(\mathrm{r}^{2}\right)$, we quantified the influence of these four variables on $\mathrm{R}_{\mathrm{S}}$. If more than one predictor showed significant effects we conducted stepwise multiple regression analyses $(\alpha=0.05$ for tolerance, collinearity $|\zeta|<0.6$ ) to determine main causes of diurnal, day-time and night-time stem $\mathrm{CO}_{2}$ efflux variability. Subsequently, multiple regression analyses were repeatedly applied by removing factors with no significant influence $(\mathrm{p}<0.05)$ until each individual tree model reached maximum likelihood (F-test, p-value).

\subsection{Results}

Stem $\mathrm{CO}_{2}$ release and its temperature responsiveness under dry and humid conditions

Mean daily $\mathrm{R}_{\mathrm{S}}$ was highly variable and ranged from 0.18 to $1.34 \mu \mathrm{mol} \mathrm{m} \mathrm{m}^{-2}$ during the dry, and between 0.07 and $0.64 \mu \mathrm{mol} \mathrm{m} \mathrm{m}^{-2} \mathrm{~s}^{-1}$ during the humid period (Table 3.1). Mean daily $\mathrm{T}_{\mathrm{T}}$ ranged between 15.7 and $16.8^{\circ} \mathrm{C}$ during the dry (minimum $10.1{ }^{\circ} \mathrm{C}$, maximum 19.9 ${ }^{\circ} \mathrm{C}$ ), and between 14.5 and $14.9{ }^{\circ} \mathrm{C}$ during the humid season (minimum $10.8{ }^{\circ} \mathrm{C}$, maximum $17.5^{\circ} \mathrm{C}$ ). In most cases, $\mathrm{R}_{\mathrm{S}}$ was higher during the dry period than under cooler and more humid conditions. Between September 2005 and April 2006, stem diameter increment was very low (Table 3.1). Due to dendrometer defects diameter increment could not be determined for all trees.

Among regression models, we found linear regression to give the most appropriate fit for the relationship between $\mathrm{R}_{\mathrm{S}}$ and temperature for both periods (Figure 3.2). The respective correlation between $\mathrm{R}_{\mathrm{S}}$ and $\mathrm{T}_{\mathrm{T}}$ or $\mathrm{T}_{\mathrm{A}}$ did not differ (not shown). 
Under dry season conditions, the response of $R_{S}$ to $T_{T}$ was highly divergent and showed strong discrepancies in the direction of response between different tree individuals. Moreover, the eight measured species showed contrasting patterns in their temperature response of $R_{S}$. Besides the commonly expected positive relationship, $R_{S}$ was significantly negative correlated with temperature or completely uncoupled from changes in temperature in certain cases (Figure 3.2). In the dry season, the temperature responsiveness of $R_{S}$ differed between day-time and night-time periods. In most of the cases, we found better correlations with data separated into day-time and night-time values than with the diurnal datasets. While most of the tree stems were more responsive to temperature during day-time hours, we found three tree species showing a higher temperature coupling during the night (Ia, Mi1, Cr; Table 3.2). The general temperature responsiveness of $R_{S}$ was unexpectedly low. For most of the tree individuals, plotting diurnal $R_{S}$ against $T_{T}$ yielded $r^{2}$ values of less than 0.5 . In two of the ten measured tree species, $\mathrm{T}_{\mathrm{T}}$ could explain more than $70 \%$ of the variability in the diurnal $\mathrm{R}_{\mathrm{S}}$. One tree of the species, Hyeronima moritziana $(\mathrm{Hm})$ showed no significant relation to $\mathrm{T}_{\mathrm{T}}$ under dry season conditions neither during the day nor the night (Table 3.2).

In the humid season, $\mathrm{R}_{\mathrm{S}}$ was mostly uncoupled from temperature; only in some cases a very weak correlation was observed (Table 3.2). Two trees showed significant relationships in the diurnal dataset $\left(r^{2}=0.13\right.$ and 0.23$)$. Two other trees were weakly, though significantly, correlated with $\mathrm{T}_{\mathrm{T}}$ during night-time only $\left(\mathrm{r}^{2}=0.22\right.$ and 0.23$)$. For the remainder species, no differences in the temperature sensitivity of $\mathrm{R}_{\mathrm{S}}$ between day- and night-time were apparent in the humid season. 


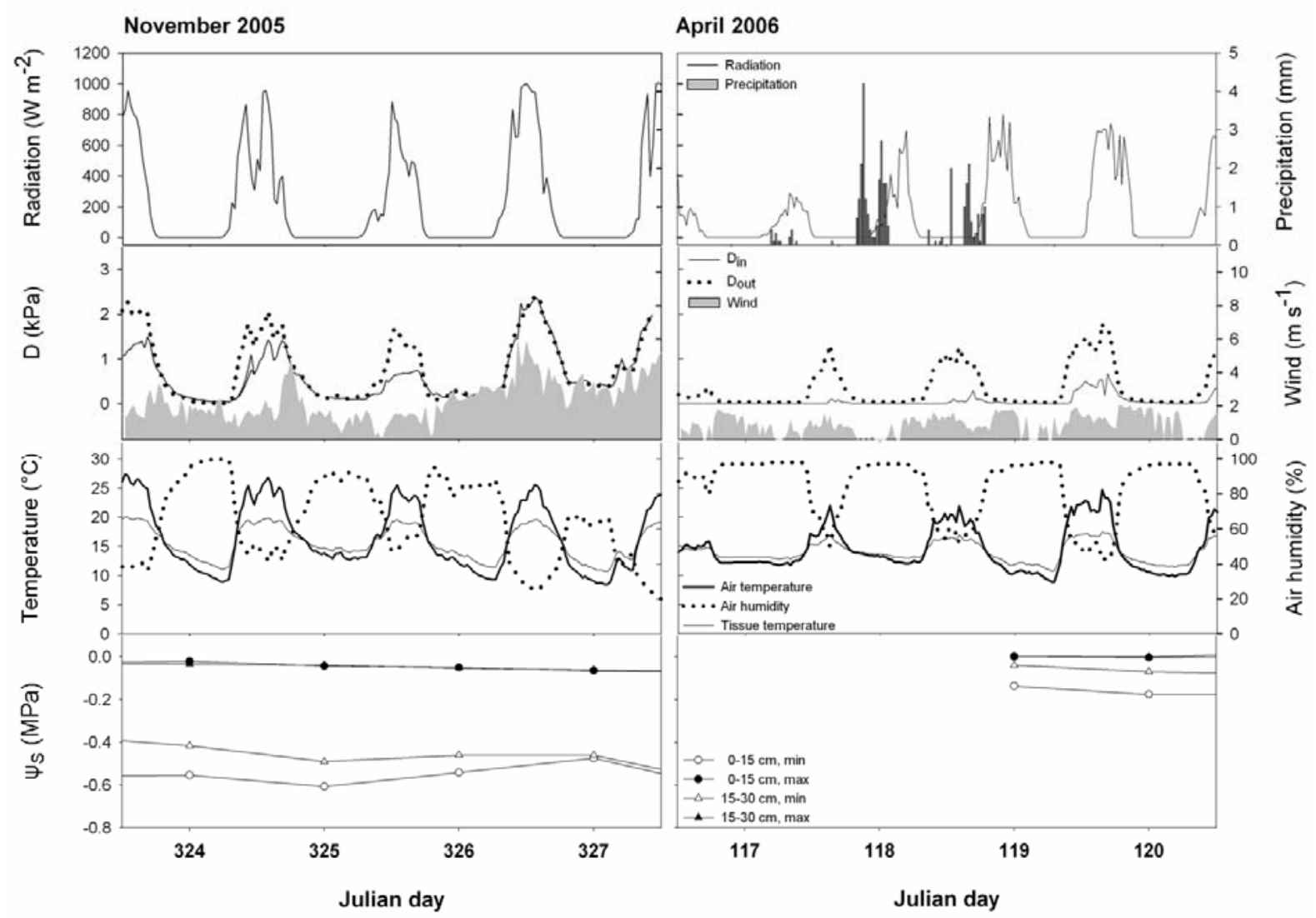

Figure 3.1. Climate data for the measurement periods in November 2005 (dry season) and April 2006 (wet season) as recorded at a nearby climate station at $2000 \mathrm{~m}$ a.s.l. (M. Richter, unpublished data). Vapour pressure deficit (D) was calculated from the climate station data $\left(D_{\text {out }}\right)$ and from climate data recorded inside the forest site at $2 \mathrm{~m}$ above ground $\left(\mathrm{D}_{\text {in }}\right)$. Soil matric potential $\left(\psi_{\mathrm{S}}\right)$ was measured at adjacent forest sites at $2000 \mathrm{~m}$ (S. Engelhardt, unpublished data).

Dependence of stem $\mathrm{CO}_{2}$ release on other meteorological predictors under dry and humid conditions

$\mathrm{R}_{\mathrm{S}}$ was linearly related to all four selected meteorological parameters (not shown). Nevertheless, neither D nor wind speed or solar radiation improved the explanatory power of the regressions with respect to $\mathrm{R}_{\mathrm{S}}$ variability under dry or humid conditions. Trees showing a significant relationship to $\mathrm{T}_{\mathrm{T}}$ also yielded comparable correlations to the other climatological parameters, most likely as a result of tight intercorrelation between the parameters. In most cases, stepwise multiple regression analysis was not applicable due to the high collinearity of the meteorological variables $(\zeta>0.6)$. An exception was wind speed, which was generally less correlated to $\mathrm{T}_{\mathrm{T}}$, $\mathrm{D}$ or solar radiation $(\zeta<0.5)$. 

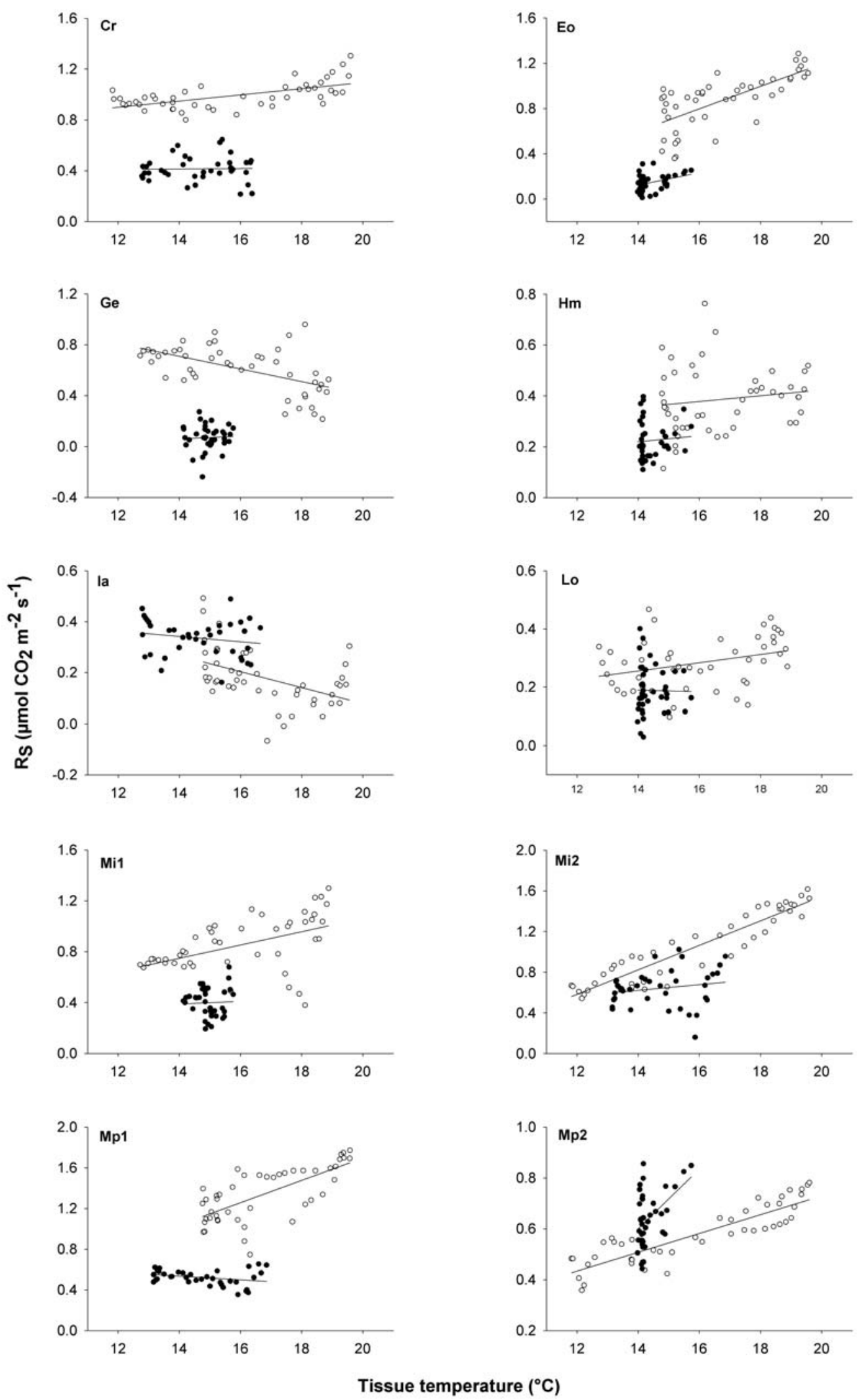

Figure 3.2. Stem $\mathrm{CO}_{2}$ release rates of 10 tree individuals at $1890 \mathrm{~m}$ elevation plotted against tissue temperature. Tissue temperature was calculated from air temperature with equation (1) and (2). Separate regression lines are given for the dry season (November 2005, $\circ$ ) and the humid season (April 2006, •) for each tree individual. Coefficients of determination are given in Table 3.2. For key to species abbreviations see Table 3.1. 
Wind speed and radiation were the main determinants of the diurnal variation in $\mathrm{R}_{\mathrm{S}}$ of Graffenrieda emarginata (Ge) during the dry season, explaining half of the variability (model adj. $\left.\mathrm{r}^{2}=0.497, \mathrm{~F}=23.25, \mathrm{p}<0.0001\right)$; the correlation with radiation was a negative one (Table 3.2). Wind speed alone was the most important factor controlling the diurnal variation in $\mathrm{R}_{\mathrm{S}}$ of Matayba inelegans (Mi1) during the dry season (model adj. $\mathrm{r}^{2}=0.337, \mathrm{~F}=24.45, \mathrm{p}<$ 0.0001); again, the relation was a negative one. Wind speed improved the regression model by explaining further $10.2 \%$ of the diurnal variation in $\mathrm{R}_{\mathrm{S}}$ in Miconia punctata $(\mathrm{Mp} 1)$. Together with $\mathrm{T}_{\mathrm{T}}$, both parameters could explain $57.7 \%$ of the variability in diurnal $\mathrm{R}_{\mathrm{S}}$ in the dry period $(\mathrm{F}=31.07, \mathrm{p}<0.0001)$. For the remaining tree species, multiple regression analysis either was not appropriate or could not improve the explanatory power of the model in comparison to a single-factor model with $\mathrm{T}_{\mathrm{T}}$ alone (Table 3.2).

Under humid conditions, the variability of $R_{S}$ could not be explained by any of the meteorological parameters. A few tree species showed significant, yet very weak, correlations to some of the predictors (Table 3.2). An exception was the night-time variability in $R_{S}$ in Matayba inelegans (Mi1), which was strong and negatively related to $\mathrm{D}\left(\mathrm{r}^{2}=0.59\right)$.

\subsection{Discussion}

\section{Sources of variation in humid season stem respiration}

During the humid measurement period, $\mathrm{R}_{\mathrm{S}}$ was independent of $\mathrm{T}_{\mathrm{T}}$ (Figure 3.2), and also seemed to be unaffected by any of the other investigated meteorological parameters (Table 3.2). Plant respiratory activity is thought to be determined by three processes, substrate supply, demand for respiratory products and potential enzyme capacity (Amthor 1995, Lambers et al. 1998, Atkin et al. 2005). Limited light availability due to cloud cover is known to strongly reduce net carbon gain of tropical forests on a seasonal as well as daily basis (Hollinger et al. 1994, Chen et al. 1999, Graham et al. 2003). In the humid season with frequent cloudiness and rainfall in the Ecuadorian Andes, assimilation rates must have been impeded, thus restricting carbohydrate supply. Porometric measurements conducted on mature canopy trees at nearby forest sites in the Podocarpus National Park showed that leaf transpiration and xylem sap flow of the tropical montane trees were substantially repressed during cloudy days and under high atmospheric humidity (Motzer et al. 2005). This may reduce the transport of dissolved $\mathrm{CO}_{2}$ with xylem water from the roots to the stem. 


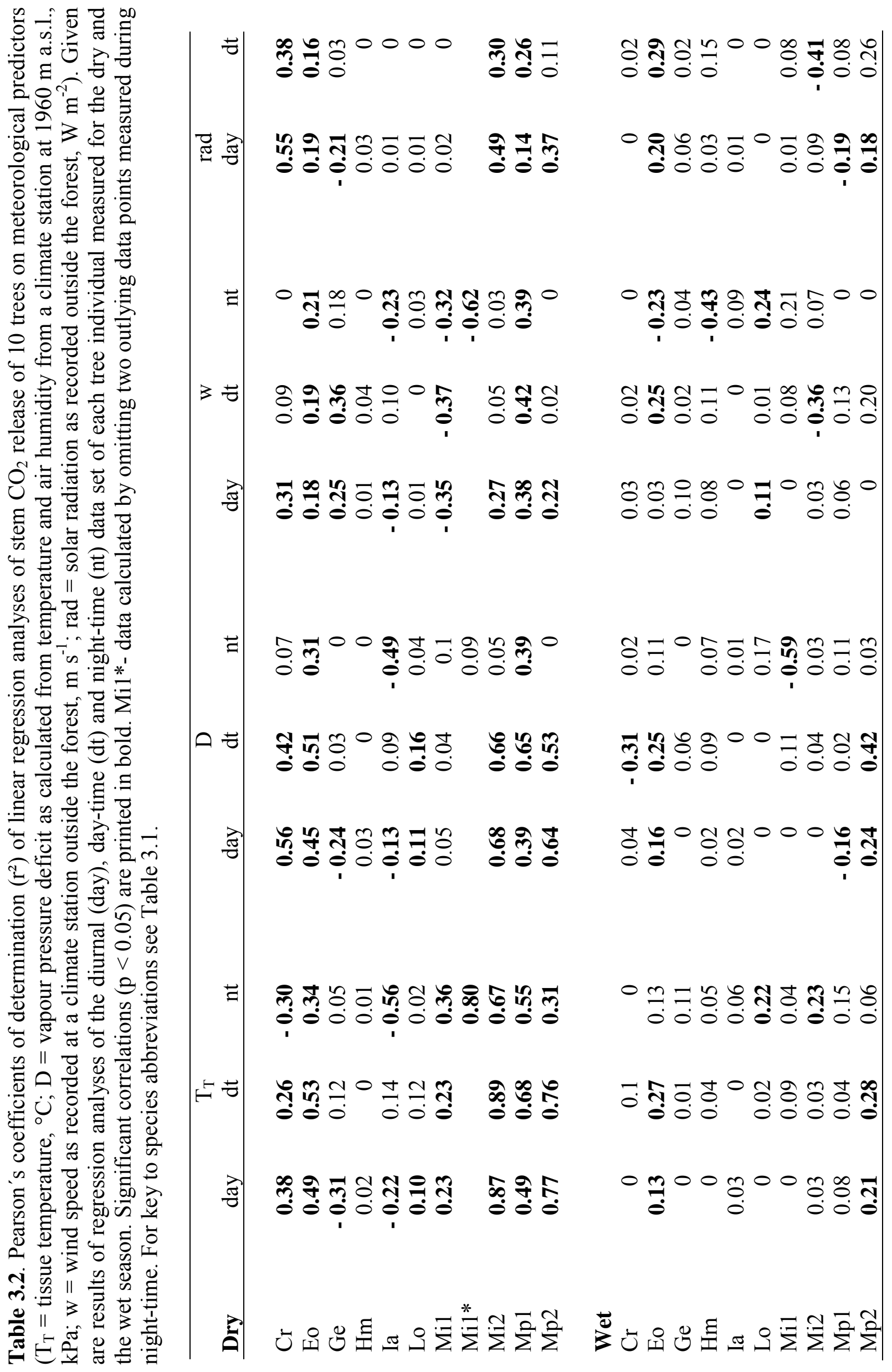


However, amount and concentration of xylem sap $\mathrm{CO}_{2}$ mainly depend on the respiratory activity of the root system involved, while smaller amounts of $\mathrm{CO}_{2}$ may also be taken up with the soil water. Differences in fine root respiration among the measured tree individuals remain unknown as well as the quantitative contribution of root respiratory $\mathrm{CO}_{2}$ release to the transpiration stream, which might finally lower or raise rates of $\mathrm{CO}_{2}$ release through the bark. We assume that several factors have contributed to a slowed down $\mathrm{R}_{\mathrm{S}}$ and a low temperature sensitivity of $R_{S}$, among which reduced substrate supply from photosynthesis, less demand for respiratory products under somewhat cooler temperatures, and a probably lower contribution of $\mathrm{CO}_{2}$ from the transpiration stream are the most likely.

\section{Sources of variation in dry season stem $\mathrm{CO}_{2}$ release}

The dry-season $R_{S}$ exceeded the wet-season rates in most of the measured trees (Figure 3.2). Overall higher rates of $R_{S}$ in the dry season may in part be explained by an assumed higher photosynthetic carbon gain accompanied by a higher carbon investment under the sunnier and hotter conditions of the dry period. However, in the Ecuadorian montane forest, annual wood production was generally low (Moser et al. 2008; Table 3.1) and distinct stem growth periodicities were not visible (Homeier 2004), implying that pronounced differences in growth related respiratory activity between dry and wet season were unlikely.

Temperature coupling was stronger during the dry season, though considerable scatter in the data was also evident (Figure 3.2). Although the diurnal amplitude of $T_{T}$ and $T_{A}$ differed between the dry compared to the humid season (Figure 3.1), the temperature response of $\mathrm{R}_{\mathrm{S}}$ to variations in $\mathrm{T}_{\mathrm{T}}$ and $\mathrm{T}_{\mathrm{A}}$ did not differ within periods (data not shown). Hence, thermal differences between $T_{T}$ and $T_{A}$ could not account for the observed discrepancies in the temperature response of $\mathrm{R}_{\mathrm{S}}$ between the two seasons. However, the actual $\mathrm{T}_{\mathrm{T}}$ of our tree stems could differ from the calculated $\mathrm{T}_{\mathrm{T}}$ values, since the continuous measurements of $\mathrm{T}_{\mathrm{T}}$ on the two stems used for the extrapolation started later in the year. Higher actual values of $\mathrm{T}_{\mathrm{T}}$ than the modelled ones could be one reason for the better temperature coupling of $R_{S}$ in the dry season.

Attempts to explain deviations from the common relationship between $R_{S}$ and temperature also focussed on time lags between temperature variation and $\mathrm{CO}_{2}$ release (Ryan 1990, Lavigne 1996, Stockfors and Linder 1998), the significance of stem photosynthetic activity (Sprugel and Benecke 1991, Gansert 1995, Pfanz 1999, Strobel 2004), and / or the $\mathrm{CO}_{2}$ transport with xylem sap flux (Edwards and Hanson 1996, Levy and Jarvis 1998, Teskey and McGuire 2002, Gansert and Burgdorf 2005). 
In three of our trees $(\mathrm{Cr}, \mathrm{Ge}, \mathrm{Hm}$; Table 3.1), the correlation coefficients between diurnal $\mathrm{T}_{\mathrm{T}}$ and $\mathrm{R}_{\mathrm{S}}$ were higher when a time lag of 1.5 to $2 \mathrm{hrs}$ was considered in the analysis (data not shown). At least in two of the stems $(\mathrm{Cr}, \mathrm{Ge}), \mathrm{R}_{\mathrm{S}}$ might indeed show a delayed temperature response, which should be related to the bigger tree size prolonging the radial diffusion pathway of $\mathrm{CO}_{2}$ (Lavigne 1996), while in the smaller stem, a lowered thermal conductivity could be the reason for the observed time delay (Hm) (Gries 2004). Bark photosynthetic activity as a significant factor could be excluded in our tree sample by comparative measurements of $\mathrm{R}_{\mathrm{S}}$ in shaded and unshaded chambers (data not shown).

Taking account of a possible influence of xylem sap $\mathrm{CO}_{2}$ to explain the large heterogeneity in $R_{S}$, we related $R_{S}$ to $D$, wind speed and solar radiation. These parameters affect stomatal conductance and transpiration and thus the xylem sap flow with its assumed $\mathrm{CO}_{2}$ transport capacity. Motzer et al. (2005) measured leaf transpiration and xylem sap flow in mature trees nearby found high stomatal sensitivities to D and strong stomatal control of sap flux in these trees. Even on short time scales (i.e. passing clouds) a sudden decline in leaf transpiration could be detected. Thus, the measurements of Motzer et al. (2005) evidenced a great diurnal and seasonal variation in sap flux rates which could well have resulted in large differences of $\mathrm{CO}_{2}$ transport in the xylem sap. This could explain why D, radiation and wind speed indeed showed a significant effect on $R_{S}$ in a number of tree species, in particular in the dry season (Table 3.2). Xylem sap effects could also account for the high release rates despite low temperature sensitivities evident for most of the tree individuals.

Several authors have argued that reduced cell turgor in the stem of droughted trees could cause a transient reduction in the respiratory activity of the living tissue (e.g. Saveyn et al. 2007). This effect would offer an explanation for the apparent day-time depression of $R_{S}$ in Graffenrieda emerginata and Ilex amboroica (Ge, Ia; Figure 3.2) during the dry season.

However, eight of the ten tree individuals showed higher, and not lower, rates of $R_{S}$ during the sunny/hot period. Although higher rates of $R_{S}$ could not be directly related to growth in case of the measured trees, the enhanced $R_{S}$ very likely indicated that the dry season climate principally favoured photosynthetic carbon gain and xylem sap flow, hence the delivery of substrate for plant respiratory activity as well as of dissolved $\mathrm{CO}_{2}$ from the transpiration stream, and thereby enhancing stem $\mathrm{CO}_{2}$ release. 
Atmospheric uncoupling of stem respiration versus temporal efficiency in energy acquisition evidence for climate-sensitive and climate-tolerant tree species?

Differences in rates of $R_{S}$ and temperature sensitivity of $R_{S}$ between the measured trees were much more pronounced in the dry than in the wet season (Table 3.1) indicating a diverging response of the trees to hotter weather conditions in this species-rich montane forest. The RSF forest with its high species diversity consists of a mixture of different tree functional types and includes typical climax and pioneer tree species co-occurring in the same stand (Homeier 2004). Moreover, our study site at $1890 \mathrm{~m}$ may represent a melting point of tree species which usually occur predominantly at higher or lower elevations, thus representing different climatic adaptations. This assumed variety in tree physiological types may offer an additional explanation for the large differences in patterns of $\mathrm{R}_{\mathrm{S}}$. For example, Ilex amboroica and Graffenrieda emarginata, the two individuals with a significant negative $\mathrm{R}_{\mathrm{S}}$-temperature response, are mostly recorded above $2000 \mathrm{~m}$ elevation in neotropical montane forests (www.mobot.org, Jorgensen and Yanis 1999) and thus are growing at their lower distribution limit in the RSF (J. Homeier, personal communication). Distribution preferences towards cooler and more humid climates at higher elevations would account for a stressinduced adverse reaction to the dry season conditions at RSF (Table 3.2, Figure 3.2). In contrast, Clethra revoluta is most abundant between 1500 and $3500 \mathrm{~m}$ a.s.l. in Ecuador (Jorgensen and Yanis 1999). This species seemed to be well adapted to the local climate variability, if the strong positive temperature response during the dry season is used as a criterion to assess performance under varying thermal regimes (Figure 3.2). Miconia punctata and Matayba inelegans are usually occurring in tropical lowland forests below 500 and 1000 m elevation, respectively (www.mobot.org, Jorgensen and Yanis 1999). Thus, they are growing at their upper distribution limit in a rather cold environment in the RSF. These species from hotter environments responded to the dry season by a relatively large increase in $\mathrm{R}_{\mathrm{S}}$ with increasing temperature, probably revealing a better adaptation to warmer climates. In contrast, Ladenbergia oblongifolia, one of the more abundant tree species between 1800 and $1900 \mathrm{~m}$ a.s.1. in the RSF (Homeier 2004), is mainly recorded below $1000 \mathrm{~m}$ elevation in the Neotropics (www.mobot.org). This tree individual showed a very weak $\mathrm{R}_{\mathrm{S}}$ response to increasing temperature (Table 3.2). 


\section{Conclusion}

Our study reports on the substantial variability in stem $\mathrm{CO}_{2}$ release between seasons and among tree individuals in a species-rich tropical montane forest. Xylem sap flow effects and species-specific differences in respiratory activity or the sensitivity of $\mathrm{R}_{\mathrm{S}}$ to atmospheric factors could be influential. The plastic response in $R_{S}$ of adapted moist forest tree species to a drier climate could help to gain insights into the acclimation potential of a mega-diverse plant community to cope with the expected climate warming. In this context, tropical montane forests are of increasing relevance, since the predicted warming by 2 to $4 \mathrm{~K}$ during this century will most likely force mesic lowland taxa to migrate upwards (Mahli and Phillips 2004, Mayle et al. 2004). Understanding and monitoring of the present forest community composition and the species-specific responses to environmental changes are a crucial basis for conservation options and will provide clues for reliable future projections.

\section{Acknowledgements}

This study was funded by the DFG (German Science Foundation) through a grant in the Research Unit 402 (Functionality in a Tropical Mountain Rainforest, subproject B6). We gratefully acknowledge the Ministerio del Ambiente Loja-Zamora for the research permit, and the Fundación Científica San Francisco (Nature and Culture International) for the ongoing support at Estación Científica San Francisco. We thank Florian Werner (University of Goettingen) for invaluable contributions on early versions of the manuscript. We are also grateful to Stefan Engelhardtt (University of Bayreuth), Rütger Rollenbeck (University of Marburg), Michael Richter and Thorsten Peters (University of Erlangen) as well as to Gerald Moser (University of Goettingen) for contributing data on soil water, climate and general stand characteristics, respectively. 


\subsection{References}

Amthor JS (1989) Respiration and crop productivity. Springer-Verlag, New York, USA, pp. 215.

Amthor JS (1995) Terrestrial higher-plant response to increasing atmospheric $\mathrm{CO}_{2}$ in relation to the global carbon cycle. Global Change Biology 1, 243-274.

Armstrong AF, Logan DC, Atkin OK (2006) On the developmental dependence of leaf respiration: responses to short- and long-term changes in growth temperature. American Journal of Botany 93, 11, 1633-1639.

Arnone JA, Körner C (1997) Temperature adaptation and acclimation potential of leaf dark respiration in two species of Ranunculus from warm and cold habitats. Arctic and Alpine Research 29, 122-125.

Atkin OK, Holly C, Ball MC (2000) Acclimation of snow gum (Eucalyptus pauciflora) leaf respiration to seasonal and diurnal variations in temperature: the importance of changes in capacity and temperature sensitivity of respiration. Plant Cell and Environment 23, 15-26.

Atkin OK, Tjoelker MG (2003) Thermal acclimation and the dynamic response of plant respiration to temperature. Trends in Plant Science 8, 343-351.

Atkin OK, Bruhn D, Hurry VM, Tjoelker MG (2005) The hot and the cold: unravelling the variable response of plant respiration to temperature. Functional Plant Biology 32, 87105.

Atkin OK, Scheurwater I, Pons TL (2006) High thermal acclimation potential of both photosynthesis and respiration in two lowland Plantago species in contrast to an alpine congeneric. Global Change Biology 12, 500-515.

Atkin OK, Scheurwater I, Pons TL (2007) Respiration as a percentage of daily photosynthesis in whole plants is homeostatic at moderate, but not high, growth temperatures. New Phytologist 174, 367-380.

Bendix J, Homeier J, Ortiz EC, Emck P, Breckle SW, Richter M, Beck E (2006) Seasonality of weather and tree phenology in a tropical evergreen mountain rain forest. International Journal of Biometeorology 50, 370-384.

Carey EV, DeLucia EH, Ball JT (1996) Stem maintenance and construction respiration in Pinus ponderosa grown in different concentrations of atmospheric $\mathrm{CO}_{2}$. Tree Physiology 16: $125-130$. 
Ceschia E (2001) Environmental effects on spatial and seasonal variations of stem respiration in European beech and Norway spruce. PhD thesis. Uppsala, Sweden: Swedish University of Agricultural Science

Chen JM, Liu J, Cihlar J, Goulden ML (1999) Daily canopy photosynthesis model through temporal and spatial for remote sensing applications. Ecological Modelling 124: 99-119.

Edward NT, Hanson PJ (1996) Stem respiration in a closed-canopy oak forest. Tree Physiology 16: 433-439.

Edwards NT, McLaughlin SB (1978) Temperature-independent diel variations of respiration rates in Quercus alba and Liriodendron tulipifera. Oikos 31: 200-206.

Edwards NT, Wullschleger SD (2000) Carbon dioxide efflux rates from stems of mature Quercus prinus L. and Acer rubrum L. trees do not appear to be affected by sapflow rates. Journal of Sustainable Forestry 10: 125-131.

Emck P (2007) A climatology of South Ecuador. PhD Thesis, University of Erlangen, Germany, pp. 272.

Enquist BJ, Kerkhoff AJ, Huxman TE, Economo EP (2007) Adaptive differences in plant physiology and ecosystem paradoxes: insights from metabolic scaling theory. Global Change Biology 13, 591-609.

Gansert D (1995) Die Wurzel- und Sprossrespiration junger Buchen (Fagus sylvatica L.) in einem montanen Moder-Buchenwald. PhD thesis. University of Göttingen, Germany, pp. 164.

Gansert D, Burkdorf M (2005) Effects of xylem sap flow on carbon dioxide efflux from stems of birch (Betula pendula Roth). Flora 200, 444-455.

Graham EA, Stephen SM, Kitajima K, Phillips NG, Wright SJ (2003) Cloud cover limits net $\mathrm{CO}_{2}$ uptake and growth of a rainforest tree during tropical rainy seasons. Philosophical Transactions of the Royal Society of London, Series B 100, 572-576.

Gries D (2004) Ökophysiologische Grundlagen und biophysikalische Steuerung von der Kohlenstoffbilanz zweier edapisch gegensätzlicher Altbuchenbestände. Habilitation thesis, University of Göttingen, Germany, pp. 589.

Gunderson CA, Norby RJ, Wullschläger SD (2000) Acclimation of photosynthesis and respiration to simulated climatic warming in northern and southern populations of Acer saccharum: laboratory and field evidence. Tree Physiology 20, 87-96.

Hollinger DY, Kelliher F M, Byers JN, Hunt JE, McSeveny TM, Weir PL (1994) Carbon dioxide exchange between an undisturbed old-growth temperate forest and the atmosphere. Ecology 75, 134-150. 
Homeier J (2004) Baumdiverstät, Waldstruktur und Wachstumsdynamik zweier tropischer Bergregenwälder in Ecuador und Costa Rica. Dissertationes Botanicae 391, pp. 207.

Horna V, Zimmermann R (2002) Carbon release from stems and branches of two tree species with contrasting phenology in a seasonally flooded Amazon forest. In: Lieberei R, Bianchi H-K, Boehm V, Reisdorff C (eds) Neotropical Ecosystems, Proceedings of the GermanBrazilian Workshop, Hamburg 2000, GKSS-Geesthacht, Germany, pp 579-587.

Jorgensen PM, Yánez SL (eds) (1999) Catalogue of the vascular plants of Ecuador. Missouri Botanical Garden Press, St. Louis, Missouri, pp. 1181.

Kerkhoff AJ, Enquist BJ, Elser JJ, Fagan WF (2005) Plant allometry, stoichiometry and the temperature-dependence of primary productivity. Global Ecology and Biogeography 14, 585-598.

Lambers H, Chapin FS, Pons TI (1998) Plant physiological ecology. Springer-Verlag, New York, pp. 540.

Larigauderie A, Körner C (1995) Acclimation of dark leaf respiration in alpine and lowland plant species. Annals of Botany 76: 245-252.

Lavigne MB (1987) Differences in stem respiration response to temperature between balsam fir trees in thinned and unthinned stands. Tree Physiology 3, 225-233.

Lavigne MB (1996) Comparing stem respiration and growth of jack pine provenances from northern and southern locations. Tree Physiology 16, 847-852.

Leuschner C, Moser G, Bertsch C, Röderstein M, Hertel D (2007) Large elevation increase in the tree root/shoot ratio in a tropical mountain forest in Ecuador. Basic and Applied Ecology 8, 219-230.

Levy PE, Jarvis PG (1998) Stem $\mathrm{CO}_{2}$ fluxes in two Sahelian shrub species (Guiera sengalensis and Combretum micranthum). Functional Ecology 12, 107-116.

Levy PE, Meir P, Allen SJ, Jarvis PG (1999) The effect of aqueous transport of $\mathrm{CO}_{2}$ in xylem sap on gas exchange of woody plants. Tree Physiology 19 53-59.

Loveys BR, Atkinson LJ, Sherlock DJ, Roberts RL, Fitter AH, Atkin OK (2003) Thermal acclimation of leaf and root respiration: an investigation comparing inherently fast- and slow-growing plant species. Global Change Biology 9, 895-910.

Malhi Y, Phillips OL (2004) Tropical forests and global atmospheric change: a synthesis. Philosophical Transactions of the Royal Society of London, Series B 359, 549-555.

Maier TA, Zarnoch SJ, Dougherty PM (1998) Effects of temperature and tissue nitrogen on dormant season stem and branch respiration in a young loblolly pine (Pinus tadea) plantation. Tree Physiology 18, 11-20. 
Maier CA, Clinton BD (2006) Relationship between stem $\mathrm{CO}_{2}$ efflux, stem sap velocity and xylem $\mathrm{CO}_{2}$ concentration in young loblolly pine trees. Plant, Cell and Environment 29: 1471-1483.

Mayle FE, Beerling DJ, Gosling WD, Bush MB (2004) Responses of Amazonian ecosystems to climatic and atmospheric carbon dioxide changes since the last glacial maximum. Philosophical Transactions of the Royal Society of London, Series B 359, 499-514.

McGuire MA, Teskey RO (2004) Estimating stem respiration in trees by a mass balance approach that accounts for internal and external fluxes of $\mathrm{CO}_{2}$. Tree Physiology 24: 571578.

Moser G, Roederstein M, Soethe N, Hertel D, Leuschner C (2008) Altitudinal changes in stand structure and biomass allocation of tropical mountain forests in relation to microclimate and soil chemistry: a transect study in Ecuador and a neotropical metaanalysis. In: Gradients in tropical mountain ecosystems of Ecuador. (eds. Beck E, J Bendix, I Kottke, F Makeschin, R Mosandl). Springer Verlag, Berlin Heidelberg, Ecological Studies 198, pp 229-242.

Motzer T, Munz N, Küppers M, Schmitt D, Anhuf D (2005) Stomatal conductance, transpiration and sap flow of tropical montane rain forest trees in the Southern Ecuadorian Andes. Tree Physiology 25, 1283-1293.

Negisi K (1979) Bark respiration rate in stem segments detached from young Pinus densiflora trees in relation to velocity of artificial sap flow. Journal of Japanese Forest Society $\mathbf{6 1}$ : 88-93.

Negisi K (1982) Dirunal fluctuations in the stem bark respiration in relationship to the wood temperature in standing young Pinus densiflora, Chamaecyparis obtusa and Quercus myrsinaefolia trees. Journal of Japanese Forest Society 64, 315-319.

Oren R, Pataki DE (2001) Transpiration in response to variation in microclimate and soil moisture in southeastern deciduous forests. Oecologia 127, 549-559.

Pfanz H (1999) Photosynthetic performance of twigs and stems of trees with and without stress. Phyton Annales Rei Botanicae 39, 29-33.

Reich PB, Wright IJ, Cavender-Bares J, Craine JM, Oleksyn J, Westoby M, Walters MB (2003) The evolution of plant functional variation: traits, spectra, and strategies. International Journal of Plant Science 164, 3, S143-S164.

Röderstein M, Hertel D, Leuschner C (2005) Above- and below-ground litter production in three tropical mountain forests (South Ecuador). Journal of Tropical Ecology 21, 483-492 
Pruyn ML, Gartner BL, Harmon ME (2002) Respiratory potential in sapwood of old versus young ponderosa pine trees in the Pacific Northwest. Tree Physiology 22: 105-116.

Pruyn ML, Gartner BL, Harmon ME (2005) Storage versus substrate limitation to bole respiratory potential in two coniferous tree species of contrasting sapwood width. Journal of Experimental Botany 56: 2637-2649.

Ryan MG (1990) Growth and maintenance respiration in stems of Pinus contorta and Pinus engelmannii. Canadian Journal of Forest Research 20, 48-57.

Saveyn A, Steppe K, Lemeur R (2007) Daytime depression in tree stem CO2 efflux rates: Is it caused by low stem trugor pressure? Annals of Botany 99, 477-485.

Saveyn A, Steppe K, Lemeur R (2008a) Report on non-temperature related variations in $\mathrm{CO}_{2}$ efflux rates from young tree stems in the dormant season. Trees 22: 165-174.

Saveyn A, Steppe K, McGuire MA, Lemeur R, Teskey RO (2008b) Stem respiration and carbon dioxide efflux of young Populus deltoides trees in relation to temperature and xylem carbon dioxide concentration. Oecologia 154: 637-649.

Schrumpf M, Guggenberger G, Schubert C, Valarezo C, Zech W (2001) Tropical montane rain forest soils - development and nutrient status along an altitudinal gradient in the south Ecuadorian Andes. Die Erde 132, 43-59.

Sprugel DG, Benecke U (1991) Measuring woody-tissue respiration and photosynthesis. In: Techniques and approaches in forest tree ecophysiology (eds. Lassoie JP, Hinckley T), CRC-Press Inc, Boston, pp. 329-355.

Stockfors J, Linder S (1998) Effect of nitrogen on the seasonal course of growth and maintenance respiration in stems of Norway spruce trees. Tree Physiology 18, 155-166.

Strobel J (2004) Die Atmung der verholzten Organe von Altbuchen (Fagus sylvatica L.) in einem Kalk- und einem Sauerhumusbuchenwald. Unpublished PhD thesis, University of Göttingen, Germany, pp. 170.

Teskey RO, McGuire MA (2002) Carbon dioxide transport in xylem causes errors in estimation of rates of respiration in stems and branches of trees. Plant Cell and Environment 25, 1571-1577.

Teskey RO, McGuire MA (2007) Measurement of stem respiration of sycamore (Plantanus occidentalis L.) trees involves internal and external fluxes of $\mathrm{CO}_{2}$ and possible transport of $\mathrm{CO}_{2}$ from roots. Plant Cell and Environment 30, 570-579.

Tjoelker MG, Oleksyn J, Reich PB (1999) Acclimation of respiration to temperature and CO2 in seedlings of boreal tree species in relation to plant size and relative growth rate. Global Change Biology 49, 679-691. 
Tjoelker MG, Oleksyn J, Reich PB (2001) Modelling respiration of vegetation: evidence for a general temperature-dependent $\mathrm{Q}_{10}$. Global Change Biology 7, 223-230.

Zach A, Horna V, Leuschner C (2008) Elevational changes in woody tissue CO2 efflux rates in a tropical mountain rainforest in southern Ecuador. Tree Physiology 28, 67-74. http://www.mobot.org/mobot/Research/ecuador/search.shtml; Missouri Botanical Garden. 


\section{Chapter}

\section{4}

\section{WoOd $\mathrm{CO}_{2}$ EFFluX Across An ElEVATION TranseCT IN AN ANDEAN MOIST FOREST: \\ SEASONALITY, RESPIRATION COMPONENTS AND \\ STAND LEVEL UPSCALE}

AleXANDRA ZACH, Viviana HoRnA AND CHRISTOPH LEUSCHNER

SUBMitTED TO: OECOLOGIA 


\subsection{Abstract}

The carbon (C) economy of tropical montane forests (TMF) is controlled by frequent cloudiness hampering assimilatory $\mathrm{CO}_{2}$ uptake, while only short periods of clear-sky conditions throughout the year allow for high assimilatory $\mathrm{C}$ gain. However, TMFs are well known for their high $\mathrm{C}$ allocation shift from above- to belowground plant parts with increasing altitude. Altitudinal changes in $\mathrm{C}$ allocation patterns must be reflected in the respiratory $\mathrm{CO}_{2}$ efflux from above- and belowground woody organs. Studying the impact of climate seasonality on wood $\mathrm{CO}_{2}$ release provides a convenient framework to understand the $\mathrm{C}$ use efficiency of TMFs. Seasonality of wood $\mathrm{CO}_{2}$ release from tropical evergreen forest trees has received little attention, but has never been studied for tropical evergreen montane trees. We used a portable $\mathrm{CO}_{2}$ measurement system, which allowed us to monitor the respiratory $\mathrm{CO}_{2}$ release from stems $\left(\mathrm{R}_{\mathrm{S}}\right)$ and coarse roots $\left(\mathrm{R}_{\mathrm{R}}\right)$ across an elevation transect with study sites at 1050, 1890 and $3050 \mathrm{~m}$ a.s.l. in an Andean moist forest in Southern Ecuador. The study aimed to (1) assess the seasonal variability of $R_{S}$ and $R_{R}$ and the impact of elevation, (2) separate woody tissue respiration into the two functional components of growth and maintenance respiration, and (3) extrapolate wood C fluxes to the forest stands. $\mathrm{R}_{\mathrm{S}}$, but not $R_{R}$ showed a clear seasonality within the measurement year. Highest rates of $R_{S}$ were measured during the dry season, though the increase in $R_{S}$ could not be simply related to temperature variation. We assumed a high degree of climate sensitivity of $\mathrm{R}_{\mathrm{S}}$, since increased $\mathrm{R}_{\mathrm{S}}$ measured under dry season conditions could not satisfactorily be related to stimulated cell growth, but could also indicate $\mathrm{C}$ losses via futile cycles. The increasing $\mathrm{C}$ allocation to the root system with elevation was associated with a large increase of the coarse root carbon use efficiency from 0.17 at $1050 \mathrm{~m}$ to 0.55 at $3050 \mathrm{~m}$. Annual carbon efflux from stems decreased from $167.1 \mathrm{~g} \mathrm{C} \mathrm{m}^{-2} \mathrm{yr}^{-1}$ at $1050 \mathrm{~m}$ to $37.7 \mathrm{~g} \mathrm{C} \mathrm{m}^{-2} \mathrm{yr}^{-1}$ at $3050 \mathrm{~m}$, while coarse root carbon release changed little from $1050 \mathrm{~m}\left(40.9 \mathrm{~g} \mathrm{C} \mathrm{m}^{-2} \mathrm{yr}^{-1}\right)$ to $3050 \mathrm{~m}\left(36.8 \mathrm{~g} \mathrm{C} \mathrm{m}^{-2} \mathrm{yr}^{-1}\right)$ reflecting the increasing importance of belowground organs at high altitudes.

Keywords: altitudinal gradient, coarse root respiration, Ecuador, growth respiration, maintenance respiration, stem respiration, tropical montane forest 


\subsection{Introduction}

At present, very limited data are available on the carbon (C) fluxes in tropical montane ecosystems (Brujinzeel and Veneklaas 1998). Studies quantifying the carbon dioxide $\left(\mathrm{CO}_{2}\right)$ efflux from woody parts of tropical montane forest trees are entirely missing. However, such information is essential if we are to gain insights into structure and productivity of the tropical montane biome.

Tropical montane forests (TMF) typically show lower aboveground productivity, lower nutrient concentrations in the soil and hence in plant organs and a slower nutrient turnover than tropical lowland forests. This has been related not only to lower temperatures, but also to the frequent cloud cover and high atmospheric humidity that limit photosynthesis and transpiration and hence assimilate supply and nutrient uptake (Bruijnzeel and Veneklaas 1998, Graham et al. 2003). On the other hand, TMFs are known to invest increasing amounts of C into the root system with increasing elevation (Brujinzeel and Veneklaas 1998, Röderstein et al. 2005, Leuschner et al. 2007, Moser et al. 2008). However, the underlying C allocation processes are still unclear (Brujinzeel and Veneklaas 1998). As is typical for the moist tropics, climate seasonality is not very pronounced in TMFs, which experience a perhumid climate throughout the year, interrupted by few drier weeks with less rainfall (Bendix et al. 2006). In this regard, the question remains of how do tropical montane communities manage to cope with prevailing low light conditions and soil nutrient restrictions. A thorough understanding of the environmental factors influencing carbon gain and carbon losses of evergreen montane trees is still lacking. To date, few studies exist on the influence of climate seasonality on physiological or ecological processes in evergreen tropical forests. For an Andean moist forest of southern Ecuador, phenology was found to be mainly triggered by cloudiness, hence by light intensity and temperature (Cueva et al. 2006). Recently, Bräuning et al. (2008) found highly inconsistent growth dynamics among several abundant tree species of the same study area, which could not simply be related to certain climatic events.

The present study aimed to analyze carbon losses from woody plant organs in relation to site characteristics and climate variations across an Andean moist forest transect in southern Ecuador. During a 1-year-measurement period we recorded stem and coarse root respiratory $\mathrm{CO}_{2}$ release at three study sites at 1050, 1890 and $3050 \mathrm{~m}$ a.s.1.. Characterized by prevailing humid climatic conditions, we could take advantage of a pronounced dry season period during our measurements to study the seasonal variability in stem and coarse root respiration of several montane tree species. In addition, we were able to profit from previous 
inventory studies conducted at the same sites to make use of standing above-and belowground biomass and annual increment data of single components.

The study has the foci to: (1) examine the seasonal variability of stem and coarse root $\mathrm{CO}_{2}$ release at three different elevations to learn about climate effects on the respiratory activity of woody organs, (2) separate woody tissue respiration into the two functional components of growth and maintenance respiration which may provide insight into patterns of $\mathrm{C}$ use of tropical montane tree species and (3) make first estimates on net annual $\mathrm{C}$ fluxes from woody parts of trees in an Andean moist forest.

\subsection{Materials \& Methods}

\section{Study area}

The study was conducted within and close to Podocarpus National Park on the eastern slopes of the southern Ecuadorian Andes between August 2005 and September 2006. Across an elevational transect of $2000 \mathrm{~m}$, we chose three forest sites of $400 \mathrm{~m}^{2}$ each and with a maximum distance of $30 \mathrm{~km}$ between the sites. The sites were a premontane forest at $1050 \mathrm{~m}$, a lower montane forest at $1890 \mathrm{~m}$ and an upper montane forest at $3050 \mathrm{~m}$ elevation (Table 4.1). The three sites have been studied previously for above- and belowground biomass and productivity (Röderstein et al. 2005, Leuschner et al. 2007, Moser et al. 2008).

The study area experiences a humid climate with a rain peak from May to July and a less humid period between November and February (Bendix et al. 2006). While easterly winds are responsible for the prevailing humid climate for most of the year, westerly foehn winds frequently cause dry and sunny days between November and February. Foehn winds were especially pronounced during our measurement period between October and December 2005, causing a marked dry season throughout the study area. The nutrient-poor soils of the area developed from granodiorite $(1050 \mathrm{~m})$, or metamorphic shale, quartzite and sandstone bedrock (1890 m, $3050 \mathrm{~m})$ (Schrumpf et al. 2001). 
Table 4.1. Characteristics of the three study sites at 1050, 1890 and $3050 \mathrm{~m}$ elevation (means $\pm \mathrm{SE}$; Moser 2008). Stem area index (SAI) is derived from a cone-shaped tree model.

\begin{tabular}{|c|c|c|c|}
\hline & $1050 \mathrm{~m}$ & $1890 \mathrm{~m}$ & $3050 \mathrm{~m}$ \\
\hline Forest type & premontane & lower montane & upper montane \\
\hline \multirow[t]{2}{*}{ Coordinates } & $\mathrm{S} 04^{\circ} 06^{\prime} 54^{\prime \prime}$ & $\mathrm{S} 03^{\circ} 58^{`} 345^{\prime \prime}$ & $\mathrm{S} 04^{\circ} 06^{\prime} 711^{\prime \prime}$ \\
\hline & W $78^{\circ} 58^{\circ} 02^{\prime \prime}$ & W 79046 $648^{\prime \prime}$ & $\mathrm{W} 79^{\circ} 10^{\prime} 581^{\prime \prime}$ \\
\hline Inclination $\left(^{\circ}\right)$ & 26 & 31 & 27 \\
\hline Rainfall (mm) & c. 1900 & c. 2200 & c. 4500 \\
\hline $\mathrm{RH}(\%)$ & 88.7 & 90.7 & 93.5 \\
\hline $\mathrm{T}_{\text {Air }}\left({ }^{\circ} \mathrm{C}\right)$ & 19.4 & 15.7 & 9.4 \\
\hline Canopy height (m) & 31.8 & 18.9 & 9.0 \\
\hline Tree height (m) & $15.6(0.7)$ & $10.1(0.4)$ & $5.2(0.3)$ \\
\hline $\mathrm{DBH}(\mathrm{cm})$ & $17.3(1.3)$ & $12.2(0.8)$ & $7.2(0.4)$ \\
\hline Basal area $\left(\mathrm{m}^{2} \mathrm{ha}^{-1}\right)$ & 33.6 & 36.9 & 42.2 \\
\hline Stem density $\left(\mathrm{n} \mathrm{ha}^{-1}\right)$ & 968 & 2333 & 8317 \\
\hline Wood density $\left(\mathrm{g} \mathrm{cm}^{-3}\right)$ & $0.64(0.03)$ & $0.60(0.04)$ & $0.69(0.03)$ \\
\hline LAI $\left(\mathrm{m}^{2} \mathrm{~m}^{-2}\right)$ & 6.0 & 5.7 & 2.2 \\
\hline $\operatorname{SAI}\left(\mathrm{m}^{2} \mathrm{~m}^{-2}\right)$ & 0.52 & 0.51 & 0.52 \\
\hline
\end{tabular}

\section{Sampling}

For measuring rates of wood $\mathrm{CO}_{2}$ release we chose 13 - 21 canopy trees per site. The tree selection at each site comprised 13 - 16 different species belonging to 10 - 11 abundant families. The range of DBH (at $1.3 \mathrm{~m}$ height) was $8.7-43.8 \mathrm{~cm}$ at $1050 \mathrm{~m}, 3.0-26.5 \mathrm{~cm}$ at $1890 \mathrm{~m}$, and $2.5-17.7 \mathrm{~cm}$ at $3050 \mathrm{~m}$ (Zach et al. 2008, Appendix 1). In addition, $4-8$ woody coarse roots (diameter: $1-4 \mathrm{~cm}$ ) growing a few centimetres below the soil surface were measured at each site. The trees were equipped with dendrometer bands at breast height (1.3 $\mathrm{m})$ for stem increment measurements (accuracy: $0.01 \mathrm{~cm}$ ). Tree diameter was taken initially and at the end of the last measurement campaign to determine annual increment rates. Coarse root diameter was measured in the middle of the section enclosed by the measurement chamber at the beginning of the study.

\section{$\mathrm{CO}_{2}$ efflux measurements}

Between August 2005 and September 2006, we conducted four measurement campaigns at each site to monitor the diurnal rates of $\mathrm{CO}_{2}$ release from stems $\left(\mathrm{R}_{\mathrm{S}}\right)$ and coarse roots $\left(R_{R}\right)$ (Figure 4.1). The individual campaigns lasted for $10-21$ days with the measurement system rotating between the three sites. The annual cycle included a pronounced dry season between October and December 2005, which in the following will be referred to as D1, and three measurement campaigns conducted under more humid climate conditions 
between August and September 2005 (H1) and from March to September 2006 (H2 and H3; Figure 4.1). The measurement campaign conducted at $1890 \mathrm{~m}$ in April 2006 (H2) was done twice; we repeated measurements when the first unusually dry part of April ( $\left.\mathrm{H} 2_{\mathrm{dry}}\right)$ was followed by more typical rainy weather ( $\mathrm{H} 2_{\text {wet }}$; Figure 4.1). Due to equipment failure at the beginning of the campaigns in August 2005, we had to reject the dataset of the first campaign (H1) from the site at $3050 \mathrm{~m}$, and the first measurements on coarse roots (H1) at $1890 \mathrm{~m}$.

Rates of $\mathrm{CO}_{2}$ release were measured using the mobile 6-chamber respiration system ANARESY 2 (Walz, Effeltrich, Germany; Appendix 2) with an integrated infrared gas analyzer for $\mathrm{CO}_{2}$ and $\mathrm{H}_{2} \mathrm{O}$ (LI-7000, Li-Cor, Inc., Lincoln, NE, USA) running in differential mode. Stem $\mathrm{CO}_{2}$ release was measured at breast height $(1.3 \mathrm{~m})$ using tightly fitted plexiglas chambers $\left(95.1 \mathrm{~cm}^{3}\right)$; coarse root sections of $15 \mathrm{~cm}$ were enclosed in cylindrical plexiglas chambers $\left(473.8 \mathrm{~cm}^{3}\right)$. We recorded air temperature and relative air humidity at $2 \mathrm{~m}$ height inside the stand using a Rotronic sensor (Rotronic AG, Bassersdorf, Switzerland) connected to the data logger of the ANARESY system (CR 10, Campbell Scientific, Logan, UT, USA). For further details on the technical equipment see Zach et al. (2008) (Chapter 2).

We used tissue temperature data logged since July 2006 to extrapolate the stem $\left(\mathrm{T}_{\mathrm{TS}}\right)$ and coarse root tissue temperatures $\left(\mathrm{T}_{\mathrm{TR}}\right)$ of our measurement periods. Thermocouples for tissue temperature (Ø: $3 \mathrm{~mm}$, length: $20 \mathrm{~mm}$, Siemens, München, Germany) were installed at $10 \mathrm{~mm}$ depth in the stem wood (at breast height) of 2 - 3 randomly chosen trees at 1050 and $1890 \mathrm{~m}$ (DBH: $15-20 \mathrm{~cm}$ ) and at $3050 \mathrm{~m}$ (DBH: $10-15 \mathrm{~cm}$ ). We related tissue temperature to air temperature and used this relationship to calculate $T_{T S}$ and $T_{T R}$ of the measurement campaigns from site microclimate records (Zach et al. submitted; Chapter 3).

After measurements, we extracted wood cores from all tree individuals using an increment borer (5 mm diameter, Haglöf, Långsele, Sweden) by coring horizontally from the bark to the centre of the bole. Cores were taken in the section where $\mathrm{CO}_{2}$ release was measured on the stem. Root samples were taken by cutting segments of $3-4 \mathrm{~cm}$ lenght. We recorded the fresh weight of all samples and used their length and diameter to calculate the sample volume. After drying the samples to constant weight at $70^{\circ} \mathrm{C}$, we determined wood density as the dry mass per volume of fresh wood. The dry samples were analysed for their nutrient contents (Appendix 4). 


\section{Data treatment}

Rates of $\mathrm{CO}_{2}$ release were calculated as:

$$
R=D\left[\mathrm{CO}_{2}\right] * \mathrm{~F} / \mathrm{Ac}
$$

where $R$ is the $\mathrm{CO}_{2}$ release rate $\left(\mu \mathrm{mol} \mathrm{CO} \mathrm{m}^{-2} \mathrm{~s}^{-1}\right), D\left[\mathrm{CO}_{2}\right]$ is the difference between ambient (reference gas) and chamber (sample gas) $\mathrm{CO}_{2}$ concentration, $F$ is the molar air flow rate (mol $\left.\mathrm{s}^{-1}\right)$ which passes through the chamber, and $A c$ is the surface area $\left(\mathrm{m}^{2}\right)$ of the enclosed stem or root segment. Due to a better relation of the $\mathrm{CO}_{2}$ efflux to surface area than to volume, we based our release rates on the surface area (Zach et al. 2008; Chapter 2).

\section{Separating growth and maintenance respiration}

In tropical moist forests, where maintenance respiration $\left(\mathrm{R}_{\mathrm{m}}\right)$ cannot be determined by dormant season measurements as in temperate forests (Ryan 1990, Sprugel 1990, Sprugel and Benecke 1991), $R_{m}$ is estimated by subtracting the calculated growth respiration from total $\mathrm{CO}_{2}$ efflux rates. Growth respiration $\left(R_{g}\right)$ of the tree stems $\left(\mathrm{R}_{\mathrm{Sg}}\right)$ was determined following Ryan et al. (1994):

$$
\text { (2) } \quad R_{g}=0.248^{*} p^{*} V_{G} *\left(\mathrm{C}_{\text {sample }} *\left(10^{6} \mu \mathrm{mol} / 12 \mathrm{~g} \mathrm{C}\right) *\left(1 / 365 \text { days }^{*} 86400 \mathrm{~s} \mathrm{day}^{-1}\right)\right)
$$

where 0.248 is the estimated mean carbon cost per gram carbon incorporated (Meir and Grace 2002), $p$ is the wood specific gravity $\left(\mathrm{g} \mathrm{cm}^{-3}\right), V_{G}$ is the volume of annual wood growth under the measurement chamber $\left(\mathrm{cm}^{3} \mathrm{~m}^{-2}\right)$ and $\mathrm{C}_{\text {sample }}$ is the wood carbon content $\left(\mathrm{g} \mathrm{C} \mathrm{g} \mathrm{biomass}{ }^{-1}\right)$. The annual increment of the woody tissue under the chamber was estimated from diameter increment measurements and wood specific gravity as determined for each tree stem from the wood cores. We then calculated the production of woody biomass from the sample carbon content and by assuming an ash-free dry matter content of 99.3\% (Ryan et al. 1994).

Estimates of coarse root growth respiration $\left(R_{R g}\right)$ were based on mean annual $R_{R}$ efflux rates (unit: $\mu \mathrm{mol} \mathrm{CO} \mathrm{CO}^{-3} \mathrm{~s}^{-1}$ ) and annual coarse root biomass production (Moser 2008). Coarse root biomass was assumed to contain 50\% carbon in the ash-free dry matter and growth respiration was assumed to account for $25 \%$ of the carbon content of the dry-matter production (Penning de Vries 1975, Sprugel and Benecke 1991).

\section{Up scaling of wood $\mathrm{CO}_{2}$ efflux}

Estimates of annual total carbon release at stand level were based on wood $\mathrm{CO}_{2}$ efflux measurements and forest inventories of the study sites (Moser 2008). Because there were no significant relationships between basal area and $\mathrm{R}_{\mathrm{S}}$ of the measured trees at any of the sites, we did not separate size classes (Figure 4.2a). Instead, we assumed that rates of stem 
respiration were constant across tree sizes for extrapolating stem $\mathrm{C}$ release to stand level. Carbon release for each tree stem was calculated assuming a cone-shaped stem and using tree height as a measure for stem length from the ground to the top of the tree. The calculated totals of carbon release for each tree were summed up to the stand. The cumulative vertical stand $\mathrm{C}$ fluxes were projected to the ground area by dividing the total site area (i.e., by multiplying vertical stand C flux with the stem area index, SAI). Site areas were corrected by slope angle (Table 4.1). Up-scaling did not include estimates of branch or leaf carbon release.

Coarse roots total respiration estimates were based on mean annual $R_{R}$ efflux rates $\left(\mu \mathrm{mol} \mathrm{CO}_{2} \mathrm{~m}^{-3} \mathrm{~s}^{-1}\right.$ ) and the standing coarse root biomass stock as determined by Moser (2008). Volume-based release rates were converted to biomass using the specific wood gravity as determined for the measured roots (data not shown). Coarse root biomass was assumed to consist by $50 \%$ of carbon, and ash-free matter to represent $99.3 \%$ of the biomass.

\section{Statistical analysis}

Differences between mean rates of stem respiration in the different measurement campaigns conducted at each site $(1050 \mathrm{~m}, 1890 \mathrm{~m}, 3050 \mathrm{~m})$ were tested for significance using analysis of variance (ANOVA). For the sites at $1050 \mathrm{~m}$ and $1890 \mathrm{~m}$, the daily mean $\mathrm{R}_{\mathrm{S}}$ values of the individual trees were log-transformed prior to ANOVA to achieve homogeneity of variances (Scheffé test, $\mathrm{p}<0.05$ ). Stem $\mathrm{CO}_{2}$ release data of individual trees at $3050 \mathrm{~m}$ matched parametric assumptions without transformation. We tested for significant differences in coarse root $\mathrm{CO}_{2}$ release $\left(\mathrm{R}_{\mathrm{R}}\right)$ between the measurement campaigns at each site using the same procedure as for stem $\mathrm{CO}_{2}$ efflux (Scheffé test, $\mathrm{p}<0.05$ ). Root respiration data matched parametric assumptions without transformation. We used coefficient of determination $\left(\mathrm{r}^{2}\right)$ to quantify the influence of predictor variables (basal area, stem increment, nitrogen content) on stem respiration.

\subsection{Results}

Seasonality of wood $\mathrm{CO}_{2}$ efflux across the elevation transect

Mean rates of $R_{S}$ at $1050 \mathrm{~m}$ were significantly higher during D1 compared to more humid campaigns (Figure 4.1). Differences between campaigns were not significant at the sites at 1890 and $3050 \mathrm{~m}$. 

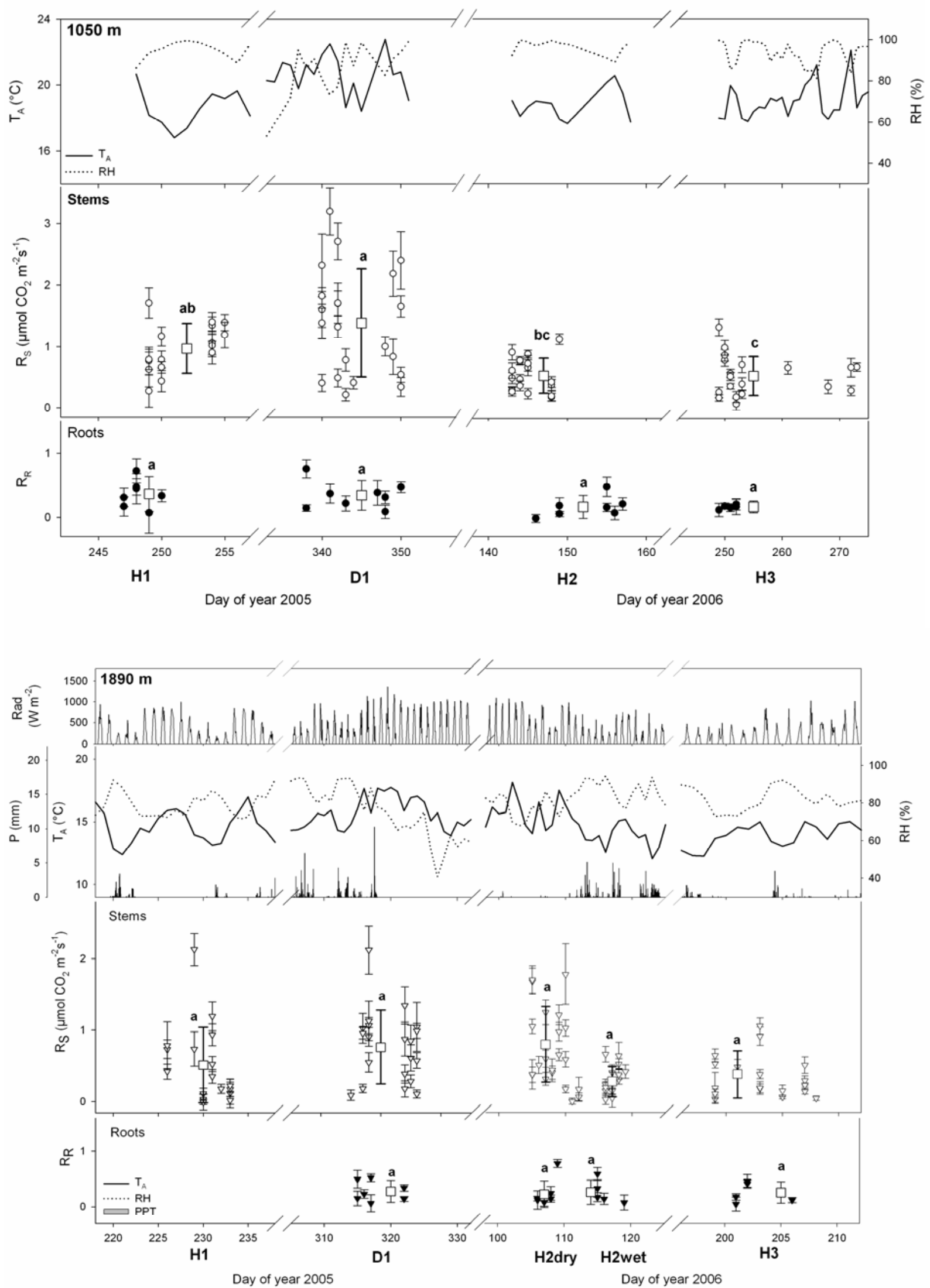


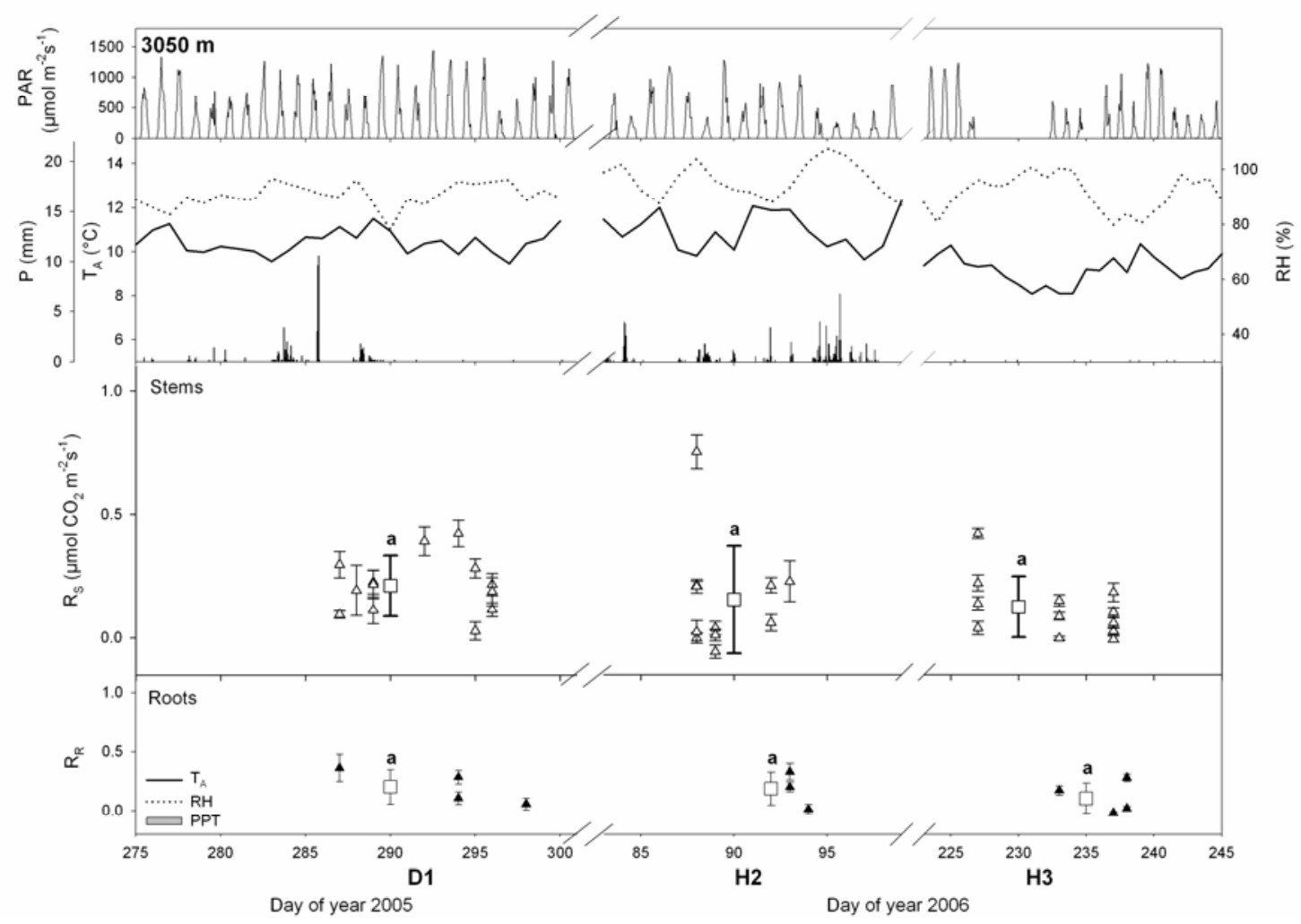

Figure 4.1. Meteorological conditions and stem $\left(\mathrm{R}_{\mathrm{S}}\right)$ and coarse root $\left(\mathrm{R}_{\mathrm{R}}\right) \mathrm{CO}_{2}$ efflux rates (mean \pm SD) in the measurement campaigns conducted between August 2005 and September 2006at the three study sites at $1050 \mathrm{~m}, 1890 \mathrm{~m}$, and $3050 \mathrm{~m}$ elevation. At each site, measurements were conducted during three humid season periods ( $\mathrm{H} 1$ to $\mathrm{H} 3$ ) and during one dry season period (D1). At $1890 \mathrm{~m}$, the measurement campaign $\mathrm{H} 2$ was done twice; we repeated measurements when the first unusually dry part of April $\left(\mathrm{H} 2_{\text {dry }}\right)$ was follow by more typical rainy weather $\left(\mathrm{H} 2_{\text {wet }}\right)$. For all sites, daily means of air temperature $\left(\mathrm{T}_{\text {Air }}\right)$ and relative air humidity (RH) and diurnal precipitation (P) are given for the study sites at 1890 and 3050 $\mathrm{m}$ as far as available. Global radiation (Rad) is provided for the site at $1890 \mathrm{~m}$ and photosynthetic active radiation (PAR) for the site at $3050 \mathrm{~m}$. Given are mean daily $\mathrm{CO}_{2}$ efflux rates for each individual tree and coarse root measured as well as the mean stand efflux per measurement campaign ( $\square$ ). Different letters indicate significant differences (Scheffé, $\mathrm{p}<$ 0.05 ) between measurement campaigns for mean stand rates of stem and coarse root $\mathrm{CO}_{2}$ efflux at each study site.

Nevertheless, highest mean rates of $\mathrm{R}_{\mathrm{S}}$ were measured during the driest and warmest period of the measurement year at all three sites (D1 and $\mathrm{H} 2_{\mathrm{dry}}$; Figure 4.1). During the measurement year, mean stand $\mathrm{R}_{\mathrm{S}}$ ranged from $0.54-1.38 \mu \mathrm{mol} \mathrm{CO} \mathrm{Cm}^{-2}$ bole surface area s${ }^{-1}$ at $1050 \mathrm{~m}$, from $0.28-0.79$ at $1890 \mathrm{~m}$ and from $0.16-0.21$ at $3050 \mathrm{~m}$; minimum rates of $\mathrm{R}_{\mathrm{S}}$ were measured under more humid conditions (H1 to $\mathrm{H} 3$ ). Between tree individuals, the variability in rates of $\mathrm{R}_{\mathrm{S}}$ was higher during $\mathrm{D} 1$ compared to $\mathrm{H} 1, \mathrm{H} 2$ and $\mathrm{H} 3$ at all sites (Appendix 5). This seasonal contrast was especially pronounced at $1890 \mathrm{~m}$ (Figure 4.1). 
Differences in stand $R_{S}$ between campaigns were less apparent at $3050 \mathrm{~m}$ (Figure 4.1). Annual mean rates of $\mathrm{R}_{\mathrm{S}}$ decreased with increasing elevation from $0.86 \pm 0.40$ (SD) $\mu \mathrm{mol}$ $\mathrm{CO}_{2} \mathrm{~m}^{-2}$ bole surface area s${ }^{-1}$ at $1050 \mathrm{~m}$ to $0.54 \pm 0.23$ at $1890 \mathrm{~m}$ and $0.19 \pm 0.03$ at $3050 \mathrm{~m}$. Elevational differences were most pronounced during D1 and least marked during H1, H2 and H3 (Figure 4.1; Appendix 5).

Mean annual rates of coarse root respiration $\left(\mathrm{R}_{\mathrm{R}}\right)$ decreased from $0.36 \pm 0.09 \mu \mathrm{mol}$ $\mathrm{CO}_{2} \mathrm{~m}^{-2}$ surface area s${ }^{-1}$ at $1050 \mathrm{~m}$ to $0.26 \pm 0.04$ at $1890 \mathrm{~m}$ and to $0.16 \pm 0.01$ at $3050 \mathrm{~m}$. Rates of $R_{R}$ did not show any seasonal trend at the three sites (Figure 4.1; Appendix 5 and 6).

\section{Growth and maintenance respiration}

Based on absolute values stem growth respiration $\left(\mathrm{R}_{\mathrm{Sg}}\right)$ decreased continuously with increasing elevation (Table 4.2). However, the average proportion of $R_{S g}$ on total $R_{S}$ decreased only slightly with altitude and accounted for $14.2 \%\left(0.11 \pm 0.12 \mu \mathrm{mol} \mathrm{CO} \mathrm{Cm}^{-2} \mathrm{~s}^{-1}\right.$, SD) at $1050 \mathrm{~m}, 13.2 \%(0.05 \pm 0.06)$ at $1890 \mathrm{~m}$ and $10.3 \%(0.01 \pm 0.02)$ at $3050 \mathrm{~m}$. At tree level, the fraction of $\mathrm{R}_{\mathrm{Sg}}$ on total $\mathrm{R}_{\mathrm{S}}$ ranged from $0-75 \%$ at $1050 \mathrm{~m}$, from $0-52 \%$ at $1890 \mathrm{~m}$ and from $0-70 \%$ at $3050 \mathrm{~m}$. We did not find any correlation between stem maintenance respiration $\left(R_{S m}\right)$ and tissue nitrogen content at any of the sites (Figure 4.2b). Mean annual $R_{S}$ was weakly correlated with annual wood increment at $1890 \mathrm{~m}$, whereas no relationship was found at 1050 and $3050 \mathrm{~m}$ (Figure 4.2c).

The fraction of coarse root growth respiration $\left(\mathrm{R}_{\mathrm{Rg}}\right)$ on total $\mathrm{R}_{\mathrm{R}}$ continuously increased with increasing elevation and amounted to $5.2 \%$ at $1050 \mathrm{~m}, 14.6 \%$ at $1890 \mathrm{~m}$ and $29.9 \%$ at $3050 \mathrm{~m}$ (Table 4.2).

\section{Annual C losses from woody tissue across the elevation transect}

Stand carbon release from stems accounted for $167.1 \mathrm{~g} \mathrm{C} \mathrm{m}^{-2}$ ground area $\mathrm{yr}^{-1}$ at 1050 $\mathrm{m}, 102.6 \mathrm{~g} \mathrm{C} \mathrm{m}^{-2}$ ground area $\mathrm{yr}^{-1}$ at $1890 \mathrm{~m}$ and $37.7 \mathrm{~g} \mathrm{C} \mathrm{m}^{-2}$ ground area $\mathrm{yr}^{-1}$ at $3050 \mathrm{~m}$ based on the stem surface area of a cone-shaped trunk model (Table 4.2). Using cylindershaped tree stems would exactly double the annual carbon flux estimation derived from the cone model.

Stand carbon release from coarse roots was 40.9, 19.2 and $36.8 \mathrm{~g} \mathrm{C} \mathrm{m}^{-2}$ root surface area $\mathrm{y}^{-1}$ at $1050 \mathrm{~m}, 1890 \mathrm{~m}$ and $3050 \mathrm{~m}$, respectively (Table 4.2). 

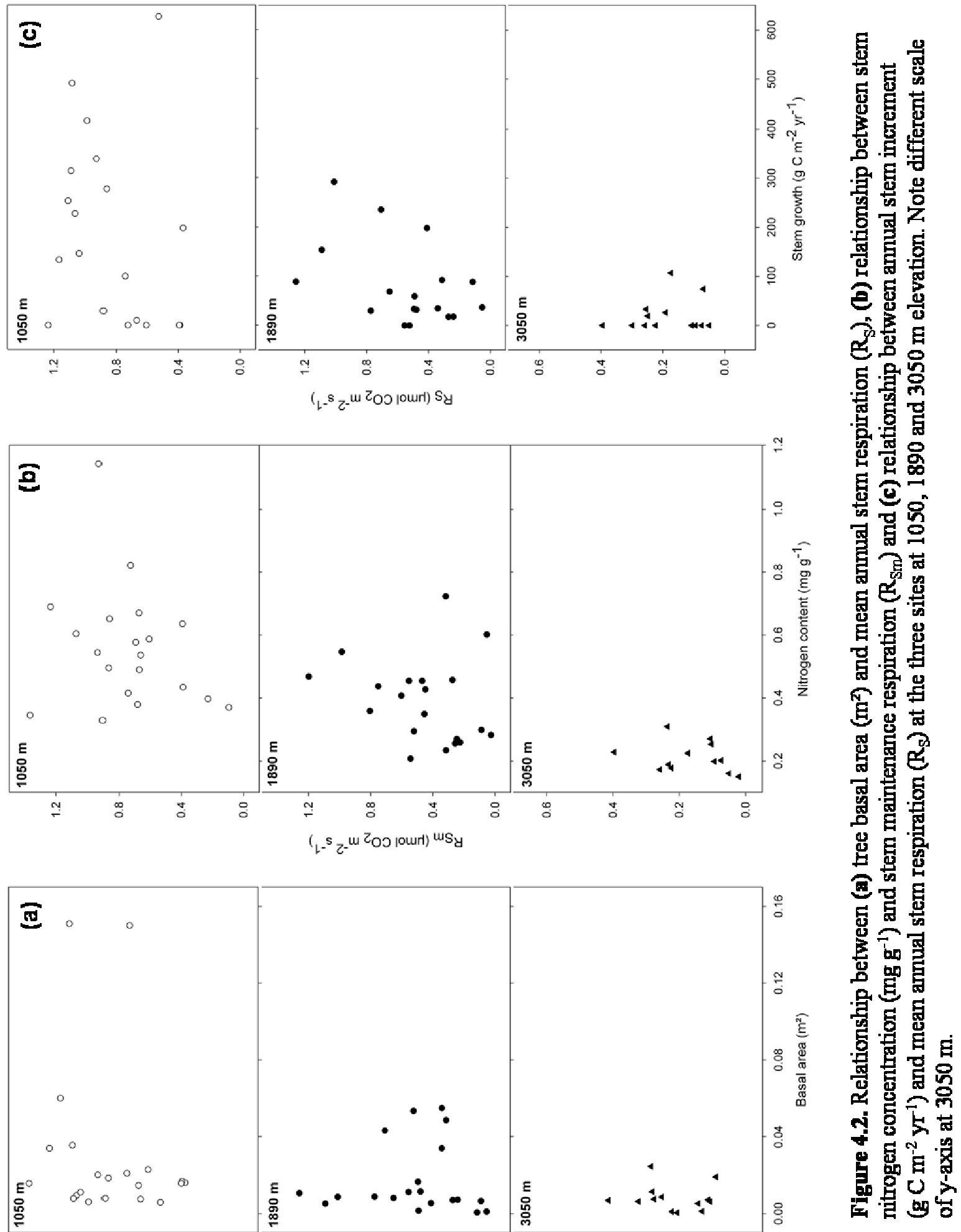


\subsection{Discussion}

\section{Seasonality of wood $\mathrm{CO}_{2}$ efflux across the elevation transect}

Few studies have been conducted on the annual variability in wood $\mathrm{CO}_{2}$ efflux of tropical plants, and most are related to drought-deciduous tree species. In habitats with strongly seasonal rainfall, woody tissue respiration is highest during the wet season of the year. This is little surprising, since leaves are shed with the onset of the dry season and wood production and associated stem growth respiration ceases (Levy and Jarvis 1998, Nepstad et al. 2002, Silva et al. 2002, Chen et al. 2003, Chambers et al. 2004). In this respect, droughtdeciduous forests are similar to cold-deciduous temperate broadleaved communities and do not allow for a direct comparison with the evergreen vegetation of the moist tropics. To our knowledge, the only study addressing the seasonality of wood $\mathrm{CO}_{2}$ efflux from tropical evergreen trees was conducted in an aseasonal wet lowland forest and found no indication of seasonality in wood carbon release (Cavaleri et al. 2006).

Our study of stem $\mathrm{CO}_{2}$ release across an Andean moist forest transect revealed that $\mathrm{R}_{\mathrm{S}}$ considerably augmented under dry season conditions, while rates of $R_{S}$ were comparatively low under the prevailing more humid climate (Figure 4.1). The increase in $R_{S}$ under dry season conditions was especially pronounced at $1050 \mathrm{~m}$ and $1890 \mathrm{~m}$. The environmental sensitivity of $R_{S}$ at $1890 \mathrm{~m}$ was corroborated by two consecutive measurement campaigns conducted in April 2006. While high rates of $\mathrm{R}_{\mathrm{S}}$ were recorded during the first exceptionally dry part of April ( $\left.\mathrm{H} 2_{\text {dry }}\right)$ with weather conditions comparable to the $\mathrm{D} 1$ campaign, mean $\mathrm{R}_{\mathrm{S}}$ dropped by $65 \%$ of the previous intensity during the rainy second part of the month $(\mathrm{H} 2$ wet; Figure 4.1). The results clearly indicate that the monitored trees were very responsive to climatic variations.

However, the higher respiration rates could not simply be explained by the higher ambient temperatures recorded during D1 (Figure 4.1). In contrast to general belief, the respiratory response to temperature was neither exponential nor clearly linear for the measured moist forest trees throughout our measurement campaigns (Appendix 3a-c). Even during D1, plotting $R_{S}$ against temperature yielded a highly scattered picture at all three sites $\left(r^{2}=0.017-0.064\right.$ : Zach et al. 2008; Chapter 2). In a previous study on diverging temperature response patterns at $1890 \mathrm{~m}$ (Zach et al. submitted; Chapter 3) we found that the $\mathrm{R}_{\mathrm{S}^{-}}$ temperature relationship varied considerably in degree and direction of response between tree individuals during the dry season campaign $\left(r^{2}=0.02-0.87\right)$, while $R_{S}$ was mostly uncoupled from temperature under wet season conditions $\left(r^{2}=0-0.21\right)$. The diverging temperature 
reactions between dry and humid season were not related to lower temperatures or diminished diurnal temperature amplitudes under humid conditions, since $\mathrm{R}_{\mathrm{S}}$ was related to stem tissue temperature and the diurnal amplitude of tissue temperature was equally weak for both seasons (Zach et al. submitted). Therefore, Zach et al. (submitted) proposed a complex interaction of abiotic factors (incoming PAR, mean daily temperature, wind speed, vapour pressure deficit, soil water availability), which affect assimilation, enzymatic activity or the demand for respiratory products and hence $\mathrm{R}_{\mathrm{S}}$ in these tropical montane forests. Further, an influence of $\mathrm{CO}_{2}$ supplied by xylem sap flux is possible (e.g., Teskey and McGuire 2002, Teskey and McGuire 2007). In conclusion, periods of highest respiratory activity were exceptionally dry and warm, but respiration was not related to temperature in a simple way.

At $3050 \mathrm{~m}$, differences in rates of $\mathrm{R}_{\mathrm{S}}$ between campaigns were less pronounced than at 1050 and $1890 \mathrm{~m}$. However, the climatic differences in terms of incoming solar radiation or mean daily temperature between campaign $\mathrm{D} 1$ and $\mathrm{H} 3$ affected $\mathrm{R}_{\mathrm{S}}$ at this high-elevation stand as well (Figure 4.1). On the other hand, the $\mathrm{R}_{\mathrm{S}}$-temperature relationship was highly variable between campaigns and between individuals showing much scatter in the data of this site in most cases (data not shown). We measured one unexplainable high rate of $\mathrm{R}_{\mathrm{S}}$ during $\mathrm{H} 2$ (Figure 4.1), which substantially increased mean rates of $R_{S}$ at $3050 \mathrm{~m}$ and hence lowered the difference between humid and dry season results. Omitting this value would yield a more clear trend of higher respiratory activity under favourable radiation and temperature conditions as are indicated by $\mathrm{D} 1$.

Coarse roots respiration did not vary between campaigns, probably as a result of low changes in soil temperature regime throughout seasons at the same depth roots were (S. Graefe, personal communication). To our knowledge, there are no comparable studies on $\mathrm{R}_{\mathrm{R}}$ in tropical montane forests.

\section{Growth and maintenance respiration}

Tropical lowland forests that are dominated by slow-growing, tall climax tree species are assumed to use about $80 \%$ of the total respired carbon for maintenance processes (Meir and Grace 2002). Ryan et al. (1994) reported $\mathrm{R}_{\mathrm{Sg}}$ values of $18 \%$ and $46 \%$ in slow- and fastgrowing tropical lowland species, respectively. In an afrotropical lowland forest, $20 \%$ of the $\mathrm{CO}_{2}$ released by tree stems was used for tissue construction (Meir and Grace 2002). Stem growth respiration in a seasonally flooded Varzea forest was below $15 \%$ of total $\mathrm{CO}_{2}$ release for most of the trees measured (Horna 2002). A proportion of $10-14 \%$ for stem growth respiration as found in our study is in the lower range of literature data. We explain this low 
figure mainly from the fact that the existing data are exclusively from tropical lowland sites with a much higher aboveground productivity than montane forests.

Table 4.2. Standing carbon stocks, productivity and C flux components of the sites at 1050 , 1890 and 3050 m elevation. Total aboveground (AG) and belowground (BG) biomass, stem (S) and coarse root $(\mathrm{CR})$ biomass $\left(\mathrm{g} \mathrm{C} \mathrm{m}^{-2}\right)$, component and total net primary (NPP) productivity $\left(\mathrm{g} \mathrm{C} \mathrm{m}^{-2} \mathrm{yr}^{-1}\right)$ and annual stem $\left(\mathrm{R}_{\mathrm{S}}\right)$ and coarse root $\left(\mathrm{R}_{\mathrm{R}}\right) \mathrm{C}$ fluxes $\left(\mathrm{g} \mathrm{C} \mathrm{m}^{-2}\right.$ ground area $\left.\mathrm{yr}^{-1}\right)$. Given are stand-level $\mathrm{C}$ flux calculations $\left(\mathrm{R}_{\mathrm{S}}\right.$ and $\left.\mathrm{R}_{\mathrm{R}}\right)$ based on own $\mathrm{CO}_{2}$ release measurements and forest inventory data (G. Moser, unpublished data), and estimates of the $\mathrm{C}$ costs of stem growth $\left(\mathrm{R}_{\mathrm{Sg}}\right)$ and coarse root growth $\left(\mathrm{R}_{\mathrm{Rg}}\right)$ respiration.

\begin{tabular}{lrrr}
\hline & $\mathbf{1 0 5 0} \mathbf{~ m}$ & $\mathbf{1 8 9 0} \mathbf{~ m}$ & $\mathbf{3 0 5 0} \mathbf{~ m}$ \\
\hline AG-biomass & 14255 & 8650 & 5610 \\
S-biomass & 13915 & 8160 & 5430 \\
Stand-level $\mathrm{R}_{\mathrm{S}}$ (cone-based) * & 167.12 & 102.62 & 37.66 \\
S-growth & 141 & 43.5 & 7 \\
\% of total S-biomass & 1.0 & 0.5 & 0.1 \\
$\mathrm{R}_{\mathrm{Sg}}(\%)$ & 14.2 & 13.2 & 10.3 \\
$\mathrm{R}_{\mathrm{Sg}}$ & 23.73 & 13.55 & 3.88 \\
$\mathrm{CUE}_{\mathrm{S}}$ & 0.46 & 0.30 & 0.16 \\
$\mathrm{R}_{\mathrm{S}} / \mathrm{S}-$ biomass & 0.012 & 0.013 & 0.007 \\
& & & \\
BG-biomass & 1605 & 1305 & 3135 \\
CR-biomass & 1470 & 995 & 2595 \\
Stand-level R & 40.9 & 19.2 & 36.8 \\
CR-growth & 8.44 & 11.40 & 44.20 \\
\% of total CR-biomass & 0.6 & 1.2 & 1.7 \\
Estimated $\mathrm{R}_{\mathrm{Rg}}$ & 2.11 & 2.80 & 11.00 \\
Estimated costs $(\%)$ & 5.2 & 14.6 & 29.9 \\
CUE & 0.17 & 0.37 & 0.55 \\
& & & \\
Total NPP & 652 & 621 & 653 \\
* & & & \\
Cylinder-based calculations would result in double the amount of the cone-based values
\end{tabular}

The proportion of $R_{S g}$ on total $R_{S}$ of our montane tree species remained constant with elevation. This is surprising, since stem growth declined 10-fold from $1050 \mathrm{~m}$ to $3050 \mathrm{~m}$ (Table 4.2). At $3050 \mathrm{~m}$, aboveground tree growth was rather low, which is thought to result mainly from unfavourable environmental conditions such as low light intensity, lower temperatures and waterlogged soils, reducing $\mathrm{C}$ gain and nutrient supply (Leuschner et al. 2007, Soethe et al. 2007). On the other hand, a higher wood density and growth-hampering conditions may result in higher construction costs of new tissue at $3050 \mathrm{~m}$ as found for high elevation trees (Brujinzeel and Veneklaas 1998). This could have counteracted low rates of $R_{S g}$. As a consequence, rates of $R_{S g}$ were more uniform across the elevation transect. $A$ different picture is found for rates of coarse root growth respiration $\left(\mathrm{R}_{\mathrm{Rg}}\right)$. In parallel to the 
enormous five-fold increase in coarse root growth from $1050 \mathrm{~m}$ to $3050 \mathrm{~m}$, the fraction of $\mathrm{R}_{\mathrm{Rg}}$ on total $\mathrm{R}_{\mathrm{R}}$ increased markedly from $5 \%(1050 \mathrm{~m})$ to $30 \%(3050 \mathrm{~m})$ in our transect, emphasizing the increasing importance of root growth with elevation (Table 4.2). However, our root respiration estimates were based on very few records on roots with diameters between 1 and $4 \mathrm{~cm}$, while the root biomass data and dry matter production values also included large woody roots $(>4 \mathrm{~cm})$ as well as smaller size fractions $(2-10 \mathrm{~mm})$. Therefore, our calculated values can only provide a rough approximation of the actual amount of $R_{R}$.

Maintenance respiration is often strongly correlated with tissue nitrogen content (McCree 1983, Waring et al. 1985, Irving and Silsbury 1987, Ryan 1990, Ryan 1991), based on the assumption that metabolic activity for maintenance functions is dependent on the protein content of plant tissue (Penning de Vries 1975). However, the strong dependence of maintenance respiration on nitrogen is a theoretical construct based on biochemical principles, which still has to be validated under field conditions (Van der Werf et al. 1992). In fact, we could not find a close relationship between $\mathrm{R}_{\mathrm{Sm}}$ and tissue $\mathrm{N}$-content at our sites (Figure 4.2b).

The calculation of growth respiration is typically based on the assumption of constant growth rates throughout the year. This assumption may be overly simplifying, since even tree species of the moist tropical lowlands show marked seasonal growth trends, triggered by changes in temperature, rainfall and nutrient availability (Clark and Clark 1994, Devall et al. 1995, Clark et al. 2003, Verheyden et al. 2004, Bräuning and Burchardt 2006). In the study area, cambial activity (and hence growth) typically ceased during periods of heavy rainfall and low light intensity (Bräuning et al. 2008, Bräuning et al. in press). On the other hand, Bräuning et al. (2008) found that cambial activity was mainly controlled by soil water availability. Even after only few rainless days, growth has halted and stem diameter started to shrink as a result of a decrease in the stem water status. Interestingly, the stem respiratory activity of our trees decreased under wet season conditions, but seemed to be stimulated by drier and warmer periods when the soil matrix potential may drop to $-0.5 \mathrm{MPa}$ (at $30 \mathrm{~cm}$ depth; S. Engelhardt, unpublished data). In this context, it is unclear if the high stem respiratory activity measured during the driest and warmest campaign (D1, Figure 4.1) was indeed related to enhanced cambial activity as previously assumed, or if higher rates of woody tissue respiration were the result of internal stress due to fluctuations in cell water status.

In a tropical evergreen lowland forest of Costa Rica, growth declined with increasing temperature and the decrease in productivity was strongest during the hottest year (El Niňo). 
At the same time, the ecosystem $\mathrm{CO}_{2}$ efflux increased (Clark and Clark 1994). Other recent studies consistently confirmed the trend of decreasing NPP in tropical forests during warmer years (Worbes 1999, Clark et al. 2003, Feeley et al. 2007). In addition, carbon respired via the alternative pathway of respiration was found to increase exponentially with increasing temperature in the humid tropics (Keller and Lerdau 1999, Lerdau and Throop 1999). A high climate sensitivity of tropical forest productivity would have serious implications for future rates of $\mathrm{CO}_{2}$ enrichment in the atmosphere under the ongoing global warming.

\section{Error propagation in extrapolating chamber measurements}

Methods for estimating stand $\mathrm{C}$ release are not standardized and uncertainties exist concerning the choice of scalar (ground area, surface area, sapwood volume) and of the allometric equations used or the representativeness (tree diameter size distribution, tree density) of the study site (Levy and Jarvis 1998, Meir and Grace 2002, Cavaleri et al. 2006). Consequently, errors can propagate considerably when chamber measurements are extrapolated to the stand level (e.g., Damesin et al. 2001). Chave et al. (2004) illustrated that the largest source of error in estimating tropical forest biomass was the allometric tree model used. The vertical stem $\mathrm{CO}_{2}$ efflux is commonly projected to a ground surface unit by multiplying with the stem area index (i.e., unit bark surface area per unit ground area; SAI). Differences in the tree model used to calculate the SAI exist (cylindrical: e.g., Levy and Jarvis 1998; cone-shaped: e.g., Meir and Grace 2002; truncated cone: e.g., Yoneda 1993) and can considerably alter efflux results. The cone-based tree model yielded 50\% lower values of stem $\mathrm{C}$ efflux than the cylindrical trunk model (Table 4.2, Table 4.3). In our study, the cone-based calculation may slightly underestimate the actual ground-projected stem $\mathrm{C}$ efflux. However, the latter must conceivably overestimate rates of bole $\mathrm{C}$ release per unit ground. Any other alternative method or allometry is not available for accurate determination of stem surfaces.

We found no significant relationship between rates of $R_{S}$ and stem diameter size or basal area at any of the sites (Figure 4.2a). This may indicate that tree size is less important for rates of $R_{S}$ than species identity or demographic positions in this species-rich tropical montane forest. Several studies calculating stand-level $\mathrm{CO}_{2}$ release in temperate (Strobel 2004, Gansert 2002, Gries 2004) and tropical forests (Ryan et al. 1994, Horna 2002, Meir and Grace 2002, Nepstad et al. 2002, Cavaleri et al. 2006) distinguished different diameter size classes prior to up-scaling. However, Ryan et al. (1994) found stem diameter to explain only $20 \%$ of the variability in the stem $\mathrm{CO}_{2}$ release of one single tropical lowland tree species. 


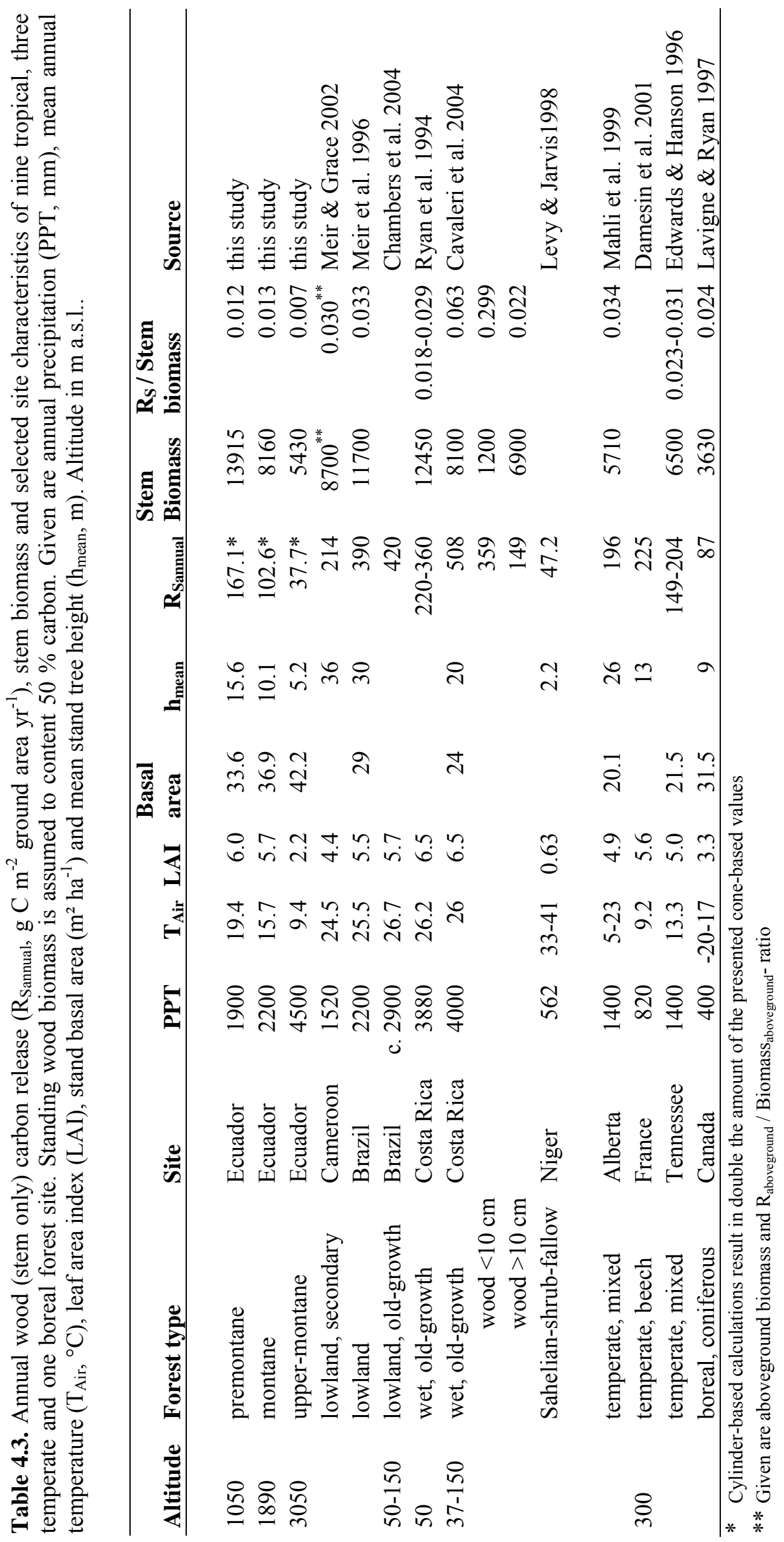




\section{Annual wood carbon release across the elevation transect}

In terms of standing carbon stocks, wood productivity and rates of stem respiration, our premontane site $(1050 \mathrm{~m})$ was similar to a wet tropical lowland forest in Costa Rica (Ryan et al. 1994, Cavaleri et al. 2006). We are not aware of any study on wood C release in a tropical montane forest. We found annual $R_{S}$ at $1890 \mathrm{~m}$ slightly lower than data reported for broadleaved temperate forests (Table 4.3). Annual $R_{S}$ at $3050 \mathrm{~m}$ was even lower than found for other sites with low aboveground productivity such as semi-arid shrub forests in the Sahelzone (Levy and Jarvis 1998) or a Canadian boreal forest (Lavigne and Ryan 1997). The unexpectedly large gap between our results from tropical montane forests and the results from temperate, boreal and subtropical forests may partly be a consequence of the use of different up-scaling procedures.

In Ecuador, annual $\mathrm{R}_{\mathrm{S}}$ declined 4.4-fold over 2000-m elevation distance. In contrast, the annual $R_{R}$ did not change between $1050 \mathrm{~m}$ and $3050 \mathrm{~m}$ as the lower specific rates of $R_{R}$ measured at $3050 \mathrm{~m}$ were compensated by the high coarse root biomass stock (Table 4.2). This shift in carbon partitioning was mirrored by a sharp increase of the coarse root carbon use efficiency (CUE: i.e., ratio of production [e.g., coarse root] to gross carbon fixation [e.g., coarse root production $\left.+R_{R}\right]$ ). On the other hand, stem CUE declined with elevation (Table 4.2). At ecosystem level, CUE gives the fraction of carbon invested into growth relative to the total amount of carbon assimilated (i.e., ratio of net primary production to gross primary production). Based on our data of annual $R_{S}$ and $R_{R}$ and annual stem and coarse root increment, we calculated a CUE at the stem level of 0.46 and a coarse root CUE of 0.17 at $1050 \mathrm{~m}$. An opposite relationship was found at $3050 \mathrm{~m}$, where stem CUE was 0.16 , whereas coarse root CUE amounted to 0.55 (Table 4.2). Low CUE values could indicate restricted nutrient availability which would hamper the use of assimilates for growth. Nutrient limitation typically leads to higher $C$ costs of constructing new tissue (Chambers et al. 2004). A preferential $\mathrm{C}$ investment into stem growth and respiration in the premontane forest is an expression of more favourable growth conditions and more fierce competition for light at $1050 \mathrm{~m}$. The upper montane forests are thought to be primarily limited by $\mathrm{N}$ shortage (Soethe et al. 2007, Leuschner et al. 2007). A high CUE of the coarse roots at $3050 \mathrm{~m}$ reflects that tree anchorage and nutrient acquisition are priority tasks in this environment. 


\section{Conclusions}

(1) The evergreen tree species of this tropical montane moist forest showed a clear seasonal pattern in stem respiratory activity.

(2) Periods of highest rates of stem respiration were particularly warm and dry, but changes in respiratory activity showed no simple relation to temperature.

(3) Our findings raise the question if the elevated rates of stem respiration measured under dry season conditions are a consequence of stimulated cell growth as was previously assumed, or if excessive carbon was respired via the alternative pathway of respiration.

(4) The degree of climate sensitivity found in this study indicates that tropical montane forests could be strongly affected by global climate change.

(5) The increasing carbon allocation to the root system with increasing elevation is associated with a large increase of the coarse root carbon use efficiency (CUE), indicating a higher belowground sink activity at high elevations.

\section{Acknowledgements}

We are grateful to the Ministerio del Ambiente Loja-Zamora for granting the research permit, and the Fundación Científica San Francisco (Nature and Culture International) for the ongoing support at Estación Científica San Francisco. We thank Gerald Moser (University of Goettingen) for contributing data on climate and general stand characteristics. We are also grateful to Florian Werner (University of Goettingen) for fruitful discussions during earlier stages of the manuscript. This study was funded by DFG (German Science Foundation) through a grant in the Research Unit 402 (Functionality in a Tropical Mountain Rainforest, subproject B6). 


\subsection{References}

Bendix J, Homeier J, Ortiz EC, Emck P, Breckle SW, Richter M, Beck E (2006) Seasonality of weather and tree phenology in a tropical evergreen mountain rain forest. International Journal of Biometeorology 50, 370-384.

Bräuning A, Burchardt I. (2006) Detection of growth dynamics in tree species of a tropical mountain rain forest in southern Ecuador. TRACE - Tree Rings in Archaeology, Climatology and Ecology 4, 127-131.

Bräuning A, von Schnakenburg P, Volland-Voigt F, Peters T (2008) Seasonal growth dynamics and its climate forcing in tropical mountain rain forest in southern Ecuador. TRACE- Tree Rings in Archeaology, Climatology and Ecology 6

Bräuning A, Homeier J, Cuevas EO, Beck E, Günter S (2008) Growth dynamics of trees in tropical mountain ecosystems. In: Gradients in a tropical mountain ecosystem of Ecuador. (eds.: Beck E, Bendix J, Kottke I, Makeschin F, Mosandl R). Springer Verlag, Berlin, Germany. Ecological Studies 198, in press.

Brujinzeel LA, Veneklaas EJ (1998) Climatic conditions and tropical montane forest productivity: The fog is not lifted yet. Ecology 79, 3-9.

Cavaleri MA, Oberbauer SF, Ryan MG (2006) Wood $\mathrm{CO}_{2}$ efflux in a primary tropical rain forest. Global Change Biology 12, 2442-2458.

Chambers JQ, Tribuzy ES, Toledo LC, Crispim BF, Higuchi N, Dos Santos J, Araújo AC, Kruijt B, Nobre AS, Trumbore SE (2004) Respiration from a tropical forest ecosystem: Partitioning of sources and low carbon use efficiency. Ecological Applications 14, 72-88.

Chave J, Condit R, Aguilar S, Hernandez A, Lao S, Perez R (2004) Error propagation and scaling for tropical forest biomass estimates. Philosophical Transactions of the Royal Society of London Series B 359, 409-420.

Chen X, Hutley LB, Eamus D (2003) Carbon balance of a tropical savanna of northern Australia. Oecologia 137, 405-416.

Clark DA, Piper SC, Keeling CD, Clark DB (1993) Tropical rain forest tree growth and atmospheric carbon dynamics linked to interannual temperature variation during 1984 2000. Philosophical Transactions of the Royal Society of London Series B 100, 58525857.

Clark DA, Clark DB (1994) Climate-induced annual variation in canopy tree growth in a Costa Rican tropical rain forest. The Journal of Ecology 82, 865-872. 
Cueva EO, Homeier J, Breckle SW, Bendix J, Emck P, Richter M, Beck E (2006) Seasonality in an evergreen tropical mountain rainforest in southern Ecuador. Ecotropica 12, 69-85.

Damesin C, Ceschia E, Le Groff N, Ottorini JM, Dufrene E (2001) Stem and branch respiration of beech: from tree measurements to estimations at the stand level. New Phytologist 153, 159-172.

Devall MS, Parresol BR, Wright S J (1995) Dendroecological analysis of Cordia alliodora, Pseudobombax septenatum and Annona spraguei in central Panama. IAWA Journal 16, 411-424.

Edwards NT, Hanson PJ (1996) Stem respiration in a closed-canopy oak forest. Tree Physiology 16, 433-439.

Feeley KJ, Wright SJ, Supardi MNN, Kassim AR, Davies SJ (2007) Decelerating growth in tropical forest trees. Ecology Letters 10, 461-469.

Gansert D (1995) Die Wurzel- und Sprossrespiration junger Buchen (Fagus sylvatica L.) in einem montanen Moder-Buchenwald. PhD thesis. University of Göttingen, Germany, pp.164.

Graham EA, Stephen SM, Kitajima K, Phillips NG, Wright SJ (2003) Cloud cover limits net $\mathrm{CO}_{2}$ uptake and growth of a rainforest tree during tropical rainy seasons. Philosophical Transactions of the Royal Society of London Series B 100, 572-576.

Gries D (2004) Ökophysiologische Grundlagen und biophysikalische Steuerung der Kohlenstoffbilanz zweier edapisch gegensätzlicher Altbuchenbestände. Habilitation thesis, University of Göttingen, Germany, pp. 589.

Homeier J (2004) Tree diversity, forest structure and growth dynamic of two tropical montane rain forests in Ecuador und Costa Rica. Dissertationes Botanicae 391, pp. 207.

Horna V (2002) Carbon release from woody parts of trees from a seasonally flooded Amazon forest near Manaus, Brazil. PhD Thesis, University of Bayreuth, pp.138.

Irving DE, Silsbury JH (1987) A comparison of the rate of maintenance respiration in some crop legumes and tobacco determined by three methods. Annals of Botany 59, 257-264.

Keller M, Lerdau M (1999) Isoprene Emission from tropical forest canopy leaves. Global Biogeochemical Cycles 13, 19-29.

Lambers H, Chapin FS, Pons TI (1998) Plant physiological ecology. Springer-Verlag, New York, pp. 540.

Lavigne MB, Ryan M.G. (1997) Growth and maintenance respiration rates of aspen, black spruce and jack pine stems ate northern and southern BOREAS sites. Tree Physiology 17, 543-551. 
Lerdau MT, Throop HL (1999) Isoprene emission and photosynthesis in a tropical forest canopy: Implications for model development. Ecological Applications 9, 1109-1117.

Leuschner C, Moser G, Bertsch C, Röderstein M, Hertel D (2007) Large altitudinal increase in the tree root/shoot ratio in tropical mountain forests of Ecuador. Basic and Applied Ecology 8, 219-230.

Levy PE, Jarvis PG (1998) Stem $\mathrm{CO}_{2}$ fluxes in two Sahelian shrub species (Guiera sengalensis and Combretum micranthum). Functional Ecology 12, 107-116.

Malhi Y, Baldocchi DD, Jarvis PG (1999) The carbon balance of tropical, temperate and boreal forests. Plant, Cell and Environment 22, 715-740.

Meir P, Grace J (2002) Scaling relationship for woody tissue respiration in two tropical rain forests. Plant, Cell and Environment 25, 963-973.

Meir P, Grace J, Miranda AC, Lloyd J (1996) Soil respiration measurements in a Brazil forest and cerrado vegetation during the wet season. In: Amazonian Deforestation and Climate (eds. Gash JHC, Nobre CA, Roberts JM, Victoria RL), Wiley, Chichester, 319-330.

Moser G (2008) Elevation effects on key processes of carbon cycling in South Ecuadorian mountain forests. PhD Thesis. University of Göttingen, Germany, pp. 125.

Moser G, Roederstein M, Soethe N, Hertel D, Leuschner C (2008) Altitudinal changes in stand structure and biomass allocation of tropical mountain forests in relation to microclimate and soil chemistry: a transect study in Ecuador and a neotropical metaanalysis. In: Gradients in tropical mountain ecosystems of Ecuador. (eds. Beck E, J Bendix, I Kottke, F Makeschin, R Mosandl). Springer Verlag, Berlin Heidelberg, Ecological Studies 198, 229-242.

Nepstad DC, Moutinho P, Dias MB et al. (2002) The effects of partial throughfall exclusion on canopy processes, above-ground production, and biogeochemistry of an Amazon forest. Journal of Geophysical Research-Atmospheres 107, 1-8.

Penning de Vries FWT (1975) Use of assimilates in higher plants. In: Photosynthesis and productivity in different environments. (ed. Cooper JP). Cambridge University Press, Cambridge.

Röderstein M, Hertel D, Leuschner C (2005) Above- and below-ground litter production in three tropical mountain forests (South Ecuador). Journal of Tropical Ecology 21, 483-492. Ryan MG (1990) Growth and maintenance respiration in stems of Pinus contorta and Pinus engelmannii. Canadian Journal of Forest Research 20, 48-57.

Ryan MG (1991) Effect of climate change on plant respiration. Ecological Applications 1, 157-167. 
Ryan MG, Hubbard RM, Clark DA, Sanford RL Jr (1994) Woody-tissue respiration of Simarouba amara and Minquartia guinensis, two wet forest trees with different growth habits. Oecologia 100, 213-220.

Schrumpf M, Guggenberger G, Schubert C, Valarezo C, Zech W (2001) Tropical montane rain forest soils - development and nutrient status along an altitudinal gradient in the south Ecuadorian Andes. Die Erde, 132, 43-59.

Silva RP, Santos J, Tribuzy ES, Chambers JQ, Nakamura S, Higuchi N (2002) Diameter increment and growth patterns of individual trees in Central Amazon, Brazil. Forest Ecology and Management 116, 295-301.

Soethe N, Lehmann J, Engels C (2006) Root morphology and anchorage of six native tree species from a tropical montane forest and an elfin forest in Ecuador. Plan and Soil 279, 173-185.

Soethe N, Lehmann J, Engels C (2007) Carbon and nutrient stocks in roots of forests at different altitudes in the Ecuadorian Andes. Journal of Tropical Ecology 23, 319-328.

Sprugel DG (1990) Components of woody-tissue respiration in young Abies amabilis trees. Trees 4, 88-98.

Sprugel DG, Benecke U (1991) Measuring woody-tissue respiration and photosynthesis. In: Techniques and approaches in forest tree ecophysiology (eds. Lassoie JP, Hinckley T), CRC-Press Inc, Boston. pp. 329-355.

Strobel J (2004) Die Atmung der verholzten Organe von Altbuchen (Fagus sylvatica L.) in einem Kalk- und einem Sauerhumusbuchenwald. PhD thesis, University of Göttingen, Germany, pp. 170.

Tanner EVJ (1985) Jamaican montane forests: nutrient capital and costs of growth. Journal of Ecology 73, 553-568.

Teskey RO, McGuire MA (2002) Carbon dioxide transport in xylem causes errors in estimation of rates of respiration in stems and branches of trees. Plant, Cell and Environment 25, 1571-1577.

Teskey RO, McGuire MA (2007) Measurement of stem respiration of sycamore (Plantanus occidentalis L.) trees involves internal and external fluxes of $\mathrm{CO}_{2}$ and possible transport of $\mathrm{CO}_{2}$ from roots. Plant, Cell and Environment, 30, 570-579.

Van der Werf A, Van den Berg G, Ravenstein HJL, Lambers H, Eisberg R (1992) Protein turnover: A significant component of maintenance respiration in roots? In: Molecular, biochemical and physiological aspects of plant respiration. (eds. Lambers H, Van der Plas LHW). SPB Academic Publishing, The Hague, pp. 61-77. 
Verheyden A, Kairo JG, Beeckman H., Koedam N (2004) Growth rings, growth ring formation and age determination in the mangrove Rhizophora mucronata. Annals of Botany 94, 59-66.

Waide RB, Zimmermann JK, Scatena FN (1998) Controls of primary productivity: lessons from the Luquillo mountains in Puerto Rico. Ecology 79, 31-37.

Waring RH, McDonald JS, Larssen S, Ericsson T, Wiren A, Arwidsson E, Ericsson A, Lohammar T (1985) Differences in chemical composition of plants grown at constant relative growth rates with stable mineral nutrition. Oecologia 66, 157-160.

Worbes M (1999) Annual growth rings, rainfall-dependent growth and long-term growth patterns of tropical trees from the Caparo forest reserve in Venezuela. Journal of Ecology 87, 391-403.

Yoneda T (1993) Surface area of woody organs of an evergreen broadleaf forest tree in Japan Southeast Asia. Journal of Plant Research 106, 229-237.

Zach A, Horna V, Leuschner C (2008) Elevational changes in woody tissue $\mathrm{CO}_{2}$ efflux rates in a tropical mountain rainforest in southern Ecuador. Tree Physiology 28, 67-74.

Zach A, Horna V, Leuschner C (submitted) Diverging temperature response of tree stem $\mathrm{CO}_{2}$ efflux to dry season conditions in a tropical montane moist forest. Trees. 


\section{Chapter}

5

The C Balance of Three Tropical Montane Forests, SOUTHERN ECUADOR 


\subsection{Introduction}

The carbon (C) balance of forest ecosystems is primarily controlled by assimilatory $\mathrm{CO}_{2}$ uptake $\left(\mathrm{A}_{\mathrm{C}}\right)$ and the release of $\mathrm{CO}_{2}$ via autotrophic respiration $\left(\mathrm{R}_{\mathrm{a}}\right)$. Part of the $\mathrm{C}$ is transferred to the soil either in form of aboveground tree litter or via belowground processes such as root turnover, the exudation of organic compounds to the rhizosphere (Luyssaert et al. 2007) and mycorrhizal hyphal turnover (Godbold et al. 2006). This fraction maintains the soil organic carbon (SOC) pool and the microbial biomass, which, in turn, releases $\mathrm{CO}_{2}$ back to the atmosphere via heterotrophic respiration $\left(\mathrm{R}_{\mathrm{h}}\right)$. Although comprehensive estimates exist of the $\mathrm{C}$ balance of differing forest biomes most of these studies combine data from a number of sources using different methods in order to reveal a generalized $\mathrm{C}$ balance of the tropical, temperate and boreal biome (Malhi et al. 1999, Malhi and Grace 2000, Luyssaert et al. 2007).

Few studies have been conducted determining all above-and belowground components of a forests' $\mathrm{C}$ balance within one study site, especially with regard to tropical forests (Malhi and Grace 2000). Even today, establishing a complete $\mathrm{C}$ balance is mainly constrained by the lack of data on the C dynamics belowground (Malhi and Grace 2000). While aboveground biomass is usually directly measured empirical data on the belowground counterpart are often missing. Instead, their estimates are based on simple assumptions. For example, Fearnside (1997) assumed belowground biomass to be $33 \%$ of aboveground biomass in a tropical lowland forest. Root production was assumed to be proportional to aboveground productivity and the above- to belowground biomass ratio (Malhi et al. 1999). However, it is commonly accepted that such assumptions have often led to underestimate the fraction of belowground carbon fluxes in forest $\mathrm{C}$ balances. Despite the lack of exact data on belowground $\mathrm{C}$ stocks and dynamics, it can be expected that a large fraction of assimilated $\mathrm{C}$ has to be transferred to the root system in order to allow forest ecosystems to maintain steady state conditions (Malhi and Grace 2000); this may especially apply to tropical montane forest (TMF) ecosystems, which are known to substantially invest into their belowground biomass with increasing altitude similar to high latitude forests (Brujinzeel and Veeneklaas 1998, Moser 2008). Boreal forests sequester $84 \%$ of their $\mathrm{C}$ below the ground and only $16 \%$ in the aerial parts, whereas in tropical lowland forests above-and belowground biomass is more or less equally partitioned (Malhi et al. 1999). The question as of how high-elevation tropical montane forests manage this substantial belowground productivity is a central topic in the ongoing debate about TMF forest structure and functionality. 
This chapter presents first $\mathrm{C}$ balances for the three tropical montane forest sites described in the previous chapters (Chapters 1 to 4 ) in an attempt to shed some light on the frequently discussed above- and belowground $\mathrm{C}$ partitioning patterns of TMFs and their changes with altitude. Therefore, the $\mathrm{CO}_{2}$ efflux measurements presented above are combined with detailed forest inventory data (Moser 2008) and data on soil respiration (Iost 2007).

\subsection{Estimating $\mathrm{C}$ balance components of three tropical montane forests}

\section{Above- and belowground biomass and biomass production}

Data on standing above- and belowground biomass (Table 5.1) and annual biomass production (Table 5.2) were provided by G. Moser (Moser 2008, unpublished data). These data refer to the very same study sites and have been assessed during an intensive measurement period from May 2003 to July 2004. Biomass data are given as $\mathrm{Mg} \mathrm{C}^{-1}$ and increment data as $\mathrm{g} \mathrm{C} \mathrm{m}^{-2} \mathrm{yr}^{-1}$ assuming a carbon content of dry matter of $50 \%$ (Penning de Vries 1975).

\section{Leaf area index}

The leaf area index (LAI) of the study sites was determined using two optical (LAI2000, hemispherical photographs) and one direct method (leaf mass-related, Table 5.3; Moser et al. submitted, Moser 2008). Moser et al. (submitted) pointed to several constraints associated with the optical methods and concluded that the direct approach (based on leaf litter production, leaf lifespan and specific leaf area data) provided the most reliable estimate of LAI for the three study sites. Consequently, we based our calculations on the directly determined LAI (Table 5.2 and Figure 5.1). Since the results of the three methods differ considerably, we summarized changes in LAI-dependent values (canopy $\mathrm{CO}_{2}$ assimilation, ecosystem respiration) in Table $\mathbf{5 . 3}$.

\section{Canopy $\mathrm{CO}_{2}$ assimilation}

Photosynthetic capacity $\left(\mathrm{A}_{\max }\right)$ was measured at the three sites using a portable open system infrared gas analyser with an integrated blue-red light source inside the leaf chamber (Li-6400, Li-Cor, Inc.). Concentration of $\mathrm{CO}_{2}$ was kept constant at $360 \mathrm{ppm}$ and air flow was $0.51 \mathrm{~min}^{-1}$. We measured $\mathrm{A}_{\max }$ at a light saturation of $1500 \mu \mathrm{mol}$ photons $\mathrm{m}^{-2} \mathrm{~s}^{-1}$ (photosynthetic photon flux density, PPFD). Data were recorded when values stabilized (after 2-3 minutes). At $3050 \mathrm{~m}$, we were able to measure attached, sun-exposed canopy leaves from 
trees within the study site for $A_{\max }$ measurements. At $1050 \mathrm{~m}$ and $1890 \mathrm{~m}$, the tall stature of trees did not allow for in situ measurement of $\mathrm{A}_{\max }$. We therefore used representative, smallstature trees in the vicinity of the study sites for $A_{\max }$ measurements on attached, sun-exposed leaves (Appendix 7).

The $\mathrm{A}_{\max }$ of sun-exposed leaves averaged $6.67 \pm 1.83(\mathrm{SD}) \mu \mathrm{mol} \mathrm{CO}_{2} \mathrm{~m}^{-2}$ leaf s $\mathrm{s}^{-1}, 6.39$ \pm 0.98 and $4.66 \pm 1.74$ at 1050,1890 and $3050 \mathrm{~m}$, respectively, and did not differ significantly between sites (Scheffé, $\mathrm{p}<0.05$ ). Canopy $\mathrm{CO}_{2}$ assimilation $\left(\mathrm{A}_{\mathrm{C}}\right)$ of the sites was extrapolated based on the measured mean $A_{\max }$ values of sunlit leaves and LAI (Table 5.2 and 5.3). In dense tropical forests, most of the canopy leaves are not directly sun-exposed. Based on a "sun/shade" model for photosynthesis simulation, Mercado et al. (2006) calculated the fraction of shaded leaves to account for $70-85 \%$ of the canopy LAI in a mature tropical lowland forest in Brazil (LAI 5.7). We therefore assumed a fraction of $80 \%$ of the LAI to be shade-leaves and $20 \%$ to be sunlit-leaves at $1050 \mathrm{~m}$ (LAI 6.0) and $1890 \mathrm{~m}$ (LAI 5.7). In contrast, the lower leaf density at $3050 \mathrm{~m}$ (LAI 2.2) allows most of the leaves to receive full sunlight (personal observation). Here, we assumed sunlit-leaves to account for a fraction of $80 \%$, while the shaded leaf fraction constitutes $20 \%$ of the canopy LAI. We could not find any reference for the relationship between $A_{\max }$ of sun leaves and $A_{\max }$ of shade leaves in multilayered tropical canopy trees. To account for the lower photosynthetic activity of shade leaves, we instead used the proportional difference found between the $A_{\max }$ of leaves from tropical tree seedlings grown under high $\left(1000 \mu \mathrm{mol}\right.$ photons $\left.\mathrm{m}^{-2} \mathrm{~s}^{-1}\right)$ and low $(100 \mu \mathrm{mol}$ photons $\mathrm{m}^{-2} \mathrm{~s}^{-1}$ ) light intensities (Veneklaas and Poorter 1998). Here, $\mathrm{A}_{\max }$ of leaves from low-light environments was $23 \%$ lower than the $\mathrm{A}_{\max }$ of leaves grown under high-light conditions. We therefore reduced the $\mathrm{A}_{\max }$ of the sun-exposed leaves as measured at the sites for $23 \%$ and used this value as a measure of the $A_{\max }$ of the shaded canopy fraction. Since we used data on photosynthetic capacity $\left(A_{\max }\right)$, we assumed a 6-h-day for assimilation activity instead of using the entire 12 hours of daylight in order to partially compensate for the high assimilation rates.

\section{Leaf dark respiration}

At $3050 \mathrm{~m}$, leaf dark respiration rates were used as derived from light-response curves of photosynthesis (Appendix 8). We recorded light-response curves of 35 attached leaf samples of 10 canopy tree species abundant at the study site. Leaf dark respiration $\left(\mathrm{R}_{\mathrm{L}}\right)$ was measured in the dark chamber and recorded after values have stabilized. The $\mathrm{R}_{\mathrm{L}}$ values were averaged for mean stand $R_{L}$. At $3050 \mathrm{~m}$, mean $\mathrm{R}_{\mathrm{L}}$ was $0.53 \pm 0.49$ (SD) $\mu \mathrm{mol} \mathrm{CO} \mathrm{CO}^{-2}$ leaf s ${ }^{-1}$. 
For the sites at $1050 \mathrm{~m}$ and $1890 \mathrm{~m}$ we calculated $\mathrm{R}_{\mathrm{L}}$ by using the relationship between leaf dark respiration and photosynthetic capacity as described by Cavaleri et al. (2008):

$$
\mathrm{A}_{\max }=\left(10.9 * \mathrm{R}_{\mathrm{L}}\right) /\left(0.52 * \mathrm{R}_{\mathrm{L}}\right)
$$

We calculated rates of leaf dark respiration of 0.47 and $0.44 \mu \mathrm{mol} \mathrm{CO}_{2} \mathrm{~m}^{-2}$ leaf s $\mathrm{s}^{-1}$ at 1050 and $1890 \mathrm{~m}$, respectively. To account for differences in $\mathrm{R}_{\mathrm{L}}$ of sun and shade leaves, we used the proportional difference in $\mathrm{R}_{\mathrm{L}}$ measured by Veneklaas and Poorter (1998) for tropical tree seedlings as mentioned in the previous section. The authors found $\mathrm{R}_{\mathrm{L}}$ to be $53 \%$ lower in seedlings grown under low-light than under high-light conditions. Leaf dark respiration of the sun- and shade-leaf fraction was summed and extrapolated to the annual foliage dark respiration by using the LAI and assuming constant 24-h respiration rates.

\section{Woody tissue respiration}

Stem wood tissue efflux values as derived from our measurements at the three study sites were used (Chapter 4). Since branch respiration rates had not been assessed, estimates of branch $\mathrm{CO}_{2}$ release for the three study sites are based on a rough approximation. Data on wood biomass of the three sites did not distinguish between stem and branch wood, therefore a biomass-based extrapolation was not possible. Branch $\mathrm{CO}_{2}$ efflux differs from stem $\mathrm{CO}_{2}$ efflux (Sprugel and Benecke 1991); branch respiration was found to increase with increasing height in the canopy (Maier et al. 1998, Ryan et al. 1996, Cavaleri et al. 2006) and was higher than efflux rates of stems of the same diameter (Cavaleri et al. 2006). Cavaleri et al. (2006) found wood $<10 \mathrm{~cm}$ to account for $70 \%$ of the total wood $\mathrm{CO}_{2}$ efflux from various functional groups (trees, lianas, palms) in a tropical lowland forest. Lianas contributed substantially to this portion. However, half of total wood $\mathrm{CO}_{2}$ efflux derived from small diameter wood (0-2 $\mathrm{cm})$ from the upper-, mid- and lower-canopy. Based on these finding we assumed branch respiration to account for $50 \%$ of total wood respiration (i.e., stem and branches), which presumably underestimate the actual branch $\mathrm{CO}_{2}$ release rates at the three sites. However, equal respiration rates of branch and stem respiration rates has also been assumed by other studies (e.g., Ryan et al. 1995).

\section{Root and soil respiration}

We used estimates of annual coarse root carbon release as measured and extrapolated above (Chapter 4). Data of total soil organic carbon (SOC) stocks, soil respiration, heterotrophic respiration and fine root respiration have been gained at the very same study 
sites (Iost 2007). Annual root litter production was assumed to equal annual root production at the three sites (G. Moser, personal communication).

\section{Missing components}

The forest $\mathrm{C}$ balance consists of several more components which are difficult to quantify and were not available for the study sites. Such "missing values" include e.g., data on coarse woody debris, understory growth and respiration, respiration of reproductive organs, $\mathrm{C}$ losses through herbivory, exudation from roots, transfer of $\mathrm{C}$ to mycorrhiza and emission of volatile organic compounds or methan. These fractions may account for $11-20 \%$ of total NPP in tropical forests (Luyssaert et al. 2007), but were omitted from our C balance approach.

\section{Structure of results}

The standing biomass stocks of the three sites are summarized in Table 5.1. Annual C fluxes and flux components are given in Table 5.2. Differences in total $\mathrm{CO}_{2}$ influx $\left(\mathrm{A}_{\mathrm{C}}\right)$ and total ecosystem $\mathrm{CO}_{2}$ efflux $\left(\mathrm{R}_{\text {total }}\right)$ when based on the three different LAI are presented in Table 5.3. Using different LAI would result in changes of items (1), (6), (11), and (29) to (41) of Table 5.2. Figure 5.1 showed simplified diagrams of the annual $\mathrm{C}$ balance of the three study sites (based on Table 5.2). Rather than presenting precise values, the flux diagrams aim to illustrate altitudinal changes and to demonstrate principle differences between the three diverging montane forest systems.

Table 5.1. Estimated stocks of $\mathrm{C}\left(\mathrm{Mg} \mathrm{ha}^{-1}\right)$ at the three sites at 1050,1890 and $3050 \mathrm{~m}$ elevation. Biomass data from Moser (2008). Stocks of soil organic carbon (SOC) from Iost (2007).

\section{$1050 \mathrm{~m} \quad 1890 \mathrm{~m} \quad 3050 \mathrm{~m}$}

\begin{tabular}{lrrr}
\hline Above ground: & & & \\
Tree foliage & 3.4 & 4.9 & 1.8 \\
Tree wood & 139.2 & 81.6 & 54.3 \\
Total AG & 142.6 & 86.5 & 56.1 \\
& & & \\
Below ground: & & & \\
Coarse roots & 14.7 & 10.0 & 26.0 \\
Fine roots & 1.3 & 2.9 & 5.6 \\
Total BG & 16.1 & 13.1 & 31.4 \\
SOC & 48.9 & 68.0 & 126.2 \\
& & & \\
Total tree biomass & 158.6 & 99.4 & 87.5 \\
Root/total biomass & $10 \%$ & $13 \%$ & $36 \%$ \\
\hline
\end{tabular}


Table 5.2. Annual $\mathrm{C}$ fluxes $\left(\mathrm{g} \mathrm{m}^{-2} \mathrm{yr}^{-1}\right)$ at the three study sites at 1050,1890 and $3050 \mathrm{~m}$. Data sources are given in the text. SOM $=$ soil organic matter, NPP $=$ net primary production.

\begin{tabular}{|c|c|c|c|c|}
\hline & & $1050 \mathrm{~m}$ & $1890 \mathrm{~m}$ & $3050 \mathrm{~m}$ \\
\hline Above ground: & $\mathrm{AG}$ & & & \\
\hline Leaf area index & LAI & 6.0 & 5.7 & 2.2 \\
\hline (1) Canopy $\mathrm{CO}_{2}$ assimilation & $\mathrm{A}_{\mathrm{C}}$ & 3064 & 2789 & 919 \\
\hline (2) Production of foliage & $\mathrm{P}_{\mathrm{L}}$ & 253 & 248 & 90 \\
\hline (3) Production of reproductive organs & $\mathrm{P}_{\mathrm{rep}}$ & 46 & 18 & 4 \\
\hline (4) Production of twigs & $\mathrm{P}_{\mathrm{B}}$ & 57 & 44 & 20 \\
\hline (5) Production of wood & $\mathrm{P}_{\mathrm{W}}$ & 141 & 44 & 7 \\
\hline (6) Dark respiration of foliage & $\mathrm{R}_{\mathrm{L}}$ & 605 & 540 & 389 \\
\hline (7) Respiration of reproductive organs & $\mathrm{R}_{\text {rep }}$ & nk & $\mathrm{nk}$ & nk \\
\hline (8) Respiration of twigs and branches & $\mathrm{R}_{\mathrm{B}}$ & 167 & 103 & 38 \\
\hline (9) Respiration of stems & $\mathrm{R}_{\mathrm{S}}$ & 167 & 103 & 38 \\
\hline (10) Tree AG-NPP $(2)+(3)+(4)+(5)$ & $\Delta \mathrm{AG}$ & 496 & 354 & 120 \\
\hline (11) Total AG-C-efflux $(6)+(7)+(8)+(9)$ & & 939 & 745 & 464 \\
\hline (12) Total AG-C-consumption (10)+(11) & & 1435 & 1099 & 584 \\
\hline (13) Transport to roots (1)-(12) & $\mathrm{T}$ & 1629 & 1690 & 335 \\
\hline Below ground: & BG & & & \\
\hline (14) Production of coarse roots & $\mathrm{P}_{\mathrm{CR}}$ & 9 & 12 & 45 \\
\hline (15) Production of fine roots & $\mathrm{P}_{\mathrm{FR}}$ & 114 & 149 & 470 \\
\hline (16) Respiration of coarse roots & $\mathrm{R}_{\mathrm{CR}}$ & 41 & 19 & 37 \\
\hline (17) Respiration of fine roots & $\mathrm{R}_{\mathrm{FR}}$ & 536 & 144 & 30 \\
\hline (18) Tree BG-NPP (14)+(15) & $\Delta \mathrm{BG}$ & 123 & 161 & 520 \\
\hline (19) root respiration $(16)+(17)$ & $\mathrm{R}_{\mathrm{R}}$ & 576 & 164 & 67 \\
\hline \multicolumn{5}{|l|}{ Soil: } \\
\hline (20) total soil respiration & $\mathrm{R}_{\text {soil }}$ & 1303 & 932 & 383 \\
\hline (21) heterothrophic respiration (20)-(22) & $\mathrm{R}_{\mathrm{h}}$ & 767 & 788 & 353 \\
\hline (22) $\operatorname{root}(<2 \mathrm{~mm})$ contribution $(\%$ of $(20))$ & & 41 & 16 & 8 \\
\hline (23) fine root litter & $\mathrm{L}_{\mathrm{BG}}$ & 114 & 149 & 470 \\
\hline (24) coarse root litter & $\mathrm{L}_{\mathrm{BG}}$ & 9 & 12 & 45 \\
\hline (25) total tree fine litter & $\mathrm{L}_{\mathrm{AG}}$ & 355 & 310 & 113 \\
\hline (26) non-tree fine litter & $\mathrm{L}_{\mathrm{AG}}$ & 35 & 107 & 14 \\
\hline (27) SOM change $(23)+(24)+(25)+(26)-(21)$ & $\Delta \mathrm{SOM}$ & -255 & -211 & 288 \\
\hline (28) Total BG-C-efflux (19)+(21) & & 1344 & 951 & 420 \\
\hline (29) Autothrophic respiration (11)+(19) & $\mathrm{R}_{\mathrm{a}}$ & 1516 & 909 & 531 \\
\hline (30) Tree NPP (10)+(18) & & 618 & 515 & 640 \\
\hline (31) Tree NPP (1)-(29) & & 1548 & 1880 & 388 \\
\hline (32) Tree GPP (30)+(29) & & 2134 & 1423 & 1171 \\
\hline (33) Ecosystem respiration $(21)+(29)$ & $\mathrm{R}_{\text {total }}$ & 2283 & 1696 & 884 \\
\hline (34) Difference (1)-(30)+(33)+(26) & & 128 & 471 & -619 \\
\hline or $(1)-(31)+(21)+(26)$ & & 714 & 14 & 164 \\
\hline (35) $\% \mathrm{R}_{\mathrm{a}}$ of $\mathrm{A}_{\mathrm{C}}$ & & 49 & 33 & 58 \\
\hline (36) $\% R_{h}$ of $A_{C}$ & & 25 & 28 & 38 \\
\hline (37) $\% \mathrm{R}_{\mathrm{W}}$ of $\mathrm{A}_{\mathrm{C}}$ & & 11 & 7 & 8 \\
\hline (38) $\% \mathrm{NNP}$ of $\mathrm{A}_{\mathrm{C}}(32) /(1)$ & & 20 & 18 & 70 \\
\hline or $(1)-(31) /(1)$ & & 49 & 33 & 58 \\
\hline (39) $\%$ root transfer of $A_{C}(15) /(1)$ & & 53 & 61 & 36 \\
\hline (40) $\% R L$ of $A_{C}$ & & 20 & 19 & 42 \\
\hline (41) $\mathrm{R}_{\text {total }} / \mathrm{A}_{\mathrm{C}}$ & & 0.75 & 0.61 & 0.96 \\
\hline
\end{tabular}




\subsection{The $\mathrm{C}$ balance of three tropical montane forests}

\section{Canopy $\mathrm{CO}_{2}$ assimilation}

Canopy $\mathrm{CO}_{2}$ assimilation $\left(\mathrm{A}_{\mathrm{C}}\right)$ was considerably lower at $3050 \mathrm{~m}$ than at the other two sites (item (1) in Table 5.2). Including foliage respiration to estimate gross photosynthesis $\left(\mathrm{A}_{\mathrm{C}}\right.$ $+\mathrm{R}_{\mathrm{L}}$ ) resulted in values very similar to values of gross photosynthesis found for humid boreal forests (653-999 $\mathrm{g} \mathrm{C} \mathrm{m}^{-2} \mathrm{yr}^{-1}$ ) ( Luyssaert et al. 2007). However, the measured $\mathrm{A}_{\max }$ of sunlit leaves did not decline significantly along the gradient, indicating that the capacity of single leaves to assimilate $\mathrm{C}$ is not the major constraint of $\mathrm{C}$ gain at high altitudes. Instead, annual $\mathrm{A}_{\mathrm{C}}$ at $3050 \mathrm{~m}$ appeared to be restricted by a combination of several limitations, such as a low LAI, light availability due to more frequent cloudiness (Bendix et al. 2008), low temperatures and soil nutrient supply compared to 1050 and $1890 \mathrm{~m}$ (Moser et al. 2007, Leuschner et al. 2007, Moser 2008).

Depending on the LAI used for calculation, $A_{C}$ continuously declined with increasing elevation (items (B) in Table 5.3) or showed little changes from 1050 to $1890 \mathrm{~m} \mathrm{((A)}$ and (C)). Estimates of gross photosynthesis $\left(A_{C}+R_{L}\right.$, Table 5.2) based on the mass-related LAI (A)were in the range of values on gross photosynthesis reported for tropical lowland forests (Malhi et al. 1999: $3040 \mathrm{~g} \mathrm{C} \mathrm{m}^{-2} \mathrm{yr}^{-1}$; Luyssaert et al. 2007: 3145 and $3735 \mathrm{~g} \mathrm{C} \mathrm{m}^{-2} \mathrm{yr}^{-1}$ ). LAI of 5-6 are typical for tropical lowland forests (Ryan et al. 1994, Malhi et al. 1999, Meir and Grace 2002). Chambers et al. (2004) even reported a LAI of only 4.7 for a tropical lowland forest near Manaus, Brazil. Differences in the methods used to determine the LAI in tropical forests has been found to result in large uncertainties when extrapolating photosynthetic $\mathrm{CO}_{2}$ assimilation or leaf dark respiration to the stand (Cavaleri et al. 2008). However, the comparatively high $\mathrm{A}_{\mathrm{C}}$ estimated for the two TMF sites at 1050 and $1890 \mathrm{~m}$ most likely derived from the theoretical assumptions used to calculate the cumulative assimilatory $\mathrm{C}$ gain of sunlit and shaded leaves in the complex, multilayered canopy strata of tropical forest trees.

\section{Net primary production (NPP)}

More surprising than the decline in $\mathrm{A}_{\mathrm{C}}$ with increasing elevation was the contrasting result with respect to NPP along the elevational transect. Previous studies based on direct measurements of above- and belowground biomass increments have suggested that NPP remains largely constant (30) with increasing elevation from 1050 to $3050 \mathrm{~m}$ (Moser 2008), while our estimates based on $\mathrm{A}_{\mathrm{C}}$ and $\mathrm{R}_{\mathrm{a}}$ suggest that NPP declines considerably from 1050 to $3050 \mathrm{~m}$ (31). Moser (2008) has found an enormous shift in C allocation from predominately 
Table 5.3. Canopy carbon gain $\left(A_{C}\right)$ and ecosystem respiration $\left(R_{\text {total }}\right)$ based on differently determined leaf area indices (LAI; A, B, C) or mean LAI (D) for the three study sites at 1050, 1890 and $3050 \mathrm{~m}$. The differences between both $\mathrm{C}$ fluxes represent the ultimate gap in the $\mathrm{C}$ balance $(\Delta$ Flux $)$ of the three study sites. See text for data sources. Units are $\mathrm{g} \mathrm{m}^{-2} \mathrm{yr}^{-1}$ and $\mathrm{m}^{2}$ $\mathrm{m}^{-2}$ (LAI).

\begin{tabular}{lrrr}
\hline & $\mathbf{1 0 5 0 ~} \mathbf{~}$ & $\mathbf{1 8 9 0} \mathbf{~ m}$ & $\mathbf{3 0 5 0 ~ \mathbf { ~ }}$ \\
\hline (A) Leaf-mass related: & 6 & 5.7 & 2.2 \\
LAI & 3064 & 2789 & 919 \\
A $_{\mathrm{C}}$ & 2283 & 1696 & 884 \\
$\mathrm{R}_{\text {total }}$ & 781 & 1093 & 35 \\
$\Delta$ Flux & & & \\
(B) LAI-2000 (Li-Cor): & 5.1 & 3.9 & 2.9 \\
LAI & 2604 & 1908 & 1211 \\
A $_{\mathrm{C}}$ & 2192 & 1526 & 1007 \\
$\mathrm{R}_{\text {total }}$ & 412 & 382 & 204 \\
$\Delta$ Flux & & & \\
(C) Hemispherical photographs: & 2.8 & 3.0 & 2.2 \\
LAI & 1430 & 1468 & 919 \\
A $_{C}$ & 1960 & 1440 & 884 \\
$\mathrm{R}_{\text {total }}$ & -530 & 28 & 35 \\
$\Delta$ Flux & & & \\
(D) Mean (A)-(C): & 4.6 & 4.2 & 2.4 \\
LAI & 2349 & 2055 & 1002 \\
A $_{C}$ & 2141 & 1554 & 919 \\
$\mathrm{R}_{\text {total }}$ Flux & 208 & 501 & 83 \\
\hline
\end{tabular}

aboveground production at $1050 \mathrm{~m}$ towards a huge annual increment of coarse and fine root biomass at $3050 \mathrm{~m}$. However, our flux measurements indicate that this enormous belowground biomass production at the upper montane site (3050 m, Moser 2008) may be an overestimation. Basically, the amount of $\mathrm{C}$ available for maintenance and growth of the root system can be derived from $A_{C}$ and the aboveground $C$ fluxes, with the difference between both terms assumed to be available for the belowground allocation (13). Carbon transfer to the roots was 45\% in tropical lowland forests (Malhi et al. 1999). At our study site at $3050 \mathrm{~m}$, this translocation of carbon accounted for $36 \%$ (39), which corresponds to $335 \mathrm{~g} \mathrm{C} \mathrm{m}^{-2} \mathrm{yr}^{-1}$ (13). In contrast, directly measured root production was $520 \mathrm{~g} \mathrm{C} \mathrm{m}^{-2} \mathrm{yr}^{-1}$ (18) (Moser 2008), and total root respiration accounts for additional $67 \mathrm{~g} \mathrm{C} \mathrm{m}^{-2} \mathrm{yr}^{-1}$ (19), indicating a gap of 252 $\mathrm{g} \mathrm{C} \mathrm{m}^{-2} \mathrm{yr}^{-1}$ between $\mathrm{C}$ demand and supply. Additional $\mathrm{C}$ demanding processes such as rhizodecomposition, root exudation and the $\mathrm{C}$ transfer to mycorrhizae not considered here would even augment the $\mathrm{C}$ gap. Moreover, rates of fine root respiration and root contribution 
to soil respiration declined with increasing altitude, while the opposite would be expected if the transfer of $\mathrm{C}$ to below the ground was to increase with elevation (Iost 2007). On the other hand, when $A_{C}$ and $R_{L}$ were based on the higher LAI derived from LAI-2000 (B, Table 5.3), carbon delivery from aboveground amounted to $504 \mathrm{~g} \mathrm{C} \mathrm{m}^{-2} \mathrm{yr}^{-1}$ and would hence match the $\mathrm{C}$ demand of belowground processes slightly better (data not shown).

The fine root productivity at the three study sites was quantified by means of minirhizotrons (Moser 2008). At $3050 \mathrm{~m}$, some of the measurements may have been taken before a new equilibrium was reached, since the time needed to establish steady state is especially long at the upper montane site due to unfavourable growth conditions (i.e., low temperature, periodically waterlogged soils, low nutrient availability). This could have resulted in an overestimation of the fine root productivity at $3050 \mathrm{~m}$ (G. Moser, personal communication). Furthermore, extrapolating root growth from the uppermost soil layer to the total soil profile may have overestimated fine root productivity (Moser et al. submitted).

\section{Gaps in the $C$ balance and implications}

Considering the two major fluxes $A_{C}$ and $R_{\text {total }}$, the upper montane site $(3050 \mathrm{~m})$ was close to equilibrium (Table 5.2; (A) and (C) in Table 5.3). A close to steady state condition may indicate that at $3050 \mathrm{~m}$ the flux-calculated NPP (31) may be more robust than the directly measured one (item (30); Figure 5.1). Compared to the site at $3050 \mathrm{~m}$, differences between $A_{C}$ and $R_{\text {total }}$ at 1050 and $1890 \mathrm{~m}$ were much higher, ranging between $-37 \%$ (i.e., efflux is greater than influx) and $25 \%$ of $A_{C}$ at $1050 \mathrm{~m}$ and between 2 and $39 \%$ at $1890 \mathrm{~m}$ dependent on LAI. Using the averaged LAI seemed to be most robust in terms of a balanced C exchange for all three study sites (Table 5.3).

Negative changes in the SOM stock at $1050 \mathrm{~m}$ and $1890 \mathrm{~m} \mathrm{(27)}$ indicate that $\mathrm{R}_{\mathrm{h}}$ exceeded annual litter production. Soil respiration at $1050 \mathrm{~m}$ is indeed within the upper range of values reported for the humid tropics (Iost 2007). At $1890 \mathrm{~m}$, litter accumulation was visibly higher than at $1050 \mathrm{~m}$ (personal observation), so that the calculated depletion could be the result of missing litter data (e.g., coarse woody debris). At $3050 \mathrm{~m}$ the calculated changes in SOM fairly agree with the observed accumulation of SOM at the upper montane forest mainly resulting from lower temperatures and the lack of primary decomposers (Maraun et al. 2008). 


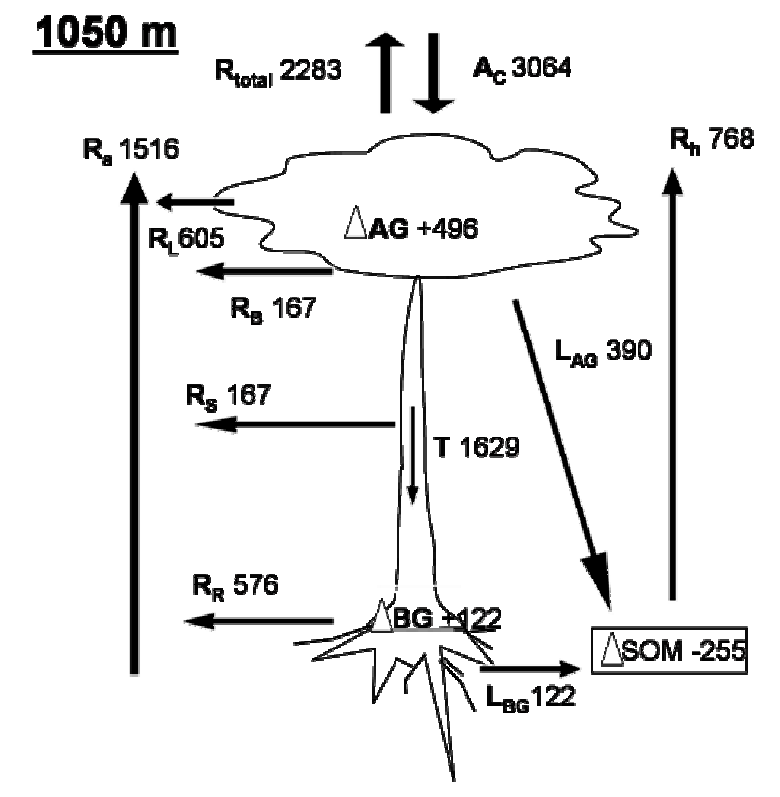

\section{$1890 \mathrm{~m}$}
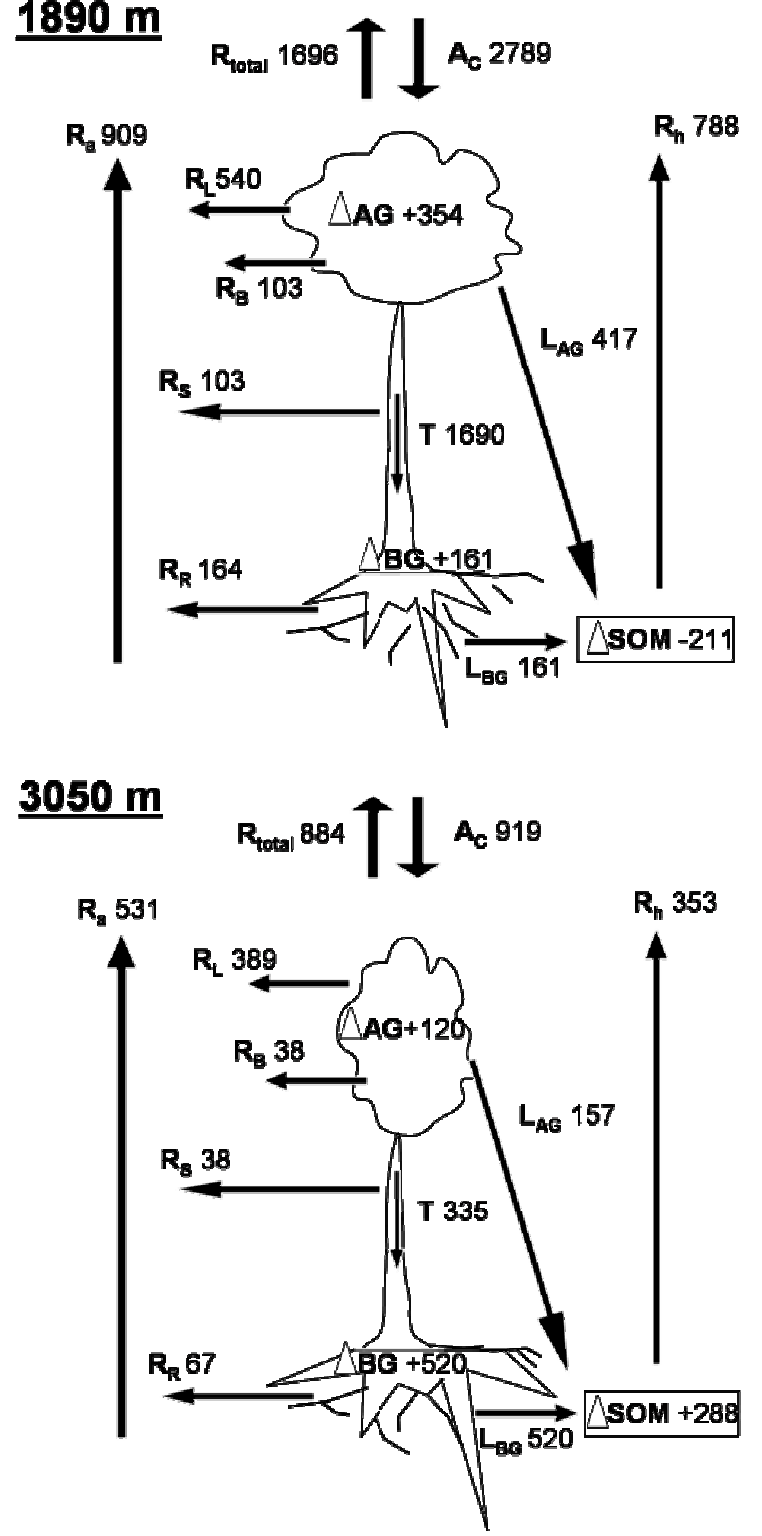

Figure 5.1. Estimated annual carbon fluxes for the three study sites at 1050, 1890 and 3050 $\mathrm{m}$ elevation. All units are $\mathrm{g} \mathrm{C} \mathrm{m}^{-2} \mathrm{yr}^{-1}$. Abbreviations are given in Table 5.2. 


\section{Conclusions}

All three study sites are considered intact, old-growth forests, which are assumed to be in $\mathrm{C}$ flux equilibrium. Consequently, $\mathrm{C}$ efflux should more or less reflect $\mathrm{C}$ influx. While at $3050 \mathrm{~m}$ this assumption was almost matched, values calculated for the two lower sites implied a large C sink (Figure 5.1). Apart from the mentioned sources of errors (e.g., extrapolation, LAI), the missing values of several components of the $\mathrm{C}$ balance (see above) and uncertainties in the quantity of other components urgently require additional and more exact observations, such as on fine root production, branch wood production and respiration, daytime and night-time respiration of sunlit and shaded leaves, and, most importantly, on the canopy $\mathrm{CO}_{2}$ fixation. Establishing complete $\mathrm{C}$ balances is challenging and the (artificial) gaps to close in $\mathrm{C}$ balances can be substantial; ranging in magnitude between $10-60 \%$ of $\mathrm{A}_{\mathrm{C}}$ for different studies and forest biomes (Luyssaert et al. 2007). A balanced $\mathrm{C}$ budget of a forest is the equilibrium between NPP and $R_{h}$, since changes in the former results in changes in the latter after a certain time lag (Malhi and Grace 2000). However, on time scales shorter than the carbon residence times of biomass or SOM, an increase in one of the two fractions (higher nutrient input and favourable PAR increases NPP, or increasing soil temperature increases $\mathrm{R}_{\mathrm{h}}$ ) will result in either a source or sink character of a given stand, especially in stands of small sizes. The magnitude of uncertainties in the balance may be related negatively to plot size, which is small in the case of our study when compared to the extent of ecosystems a $\mathrm{C}$ balance is usually referred to. Interannual fluctuations in the regional climatic or the use of data derived from different years may have also caused uncertainties in the annual net $\mathrm{C}$ flux of the investigated TMF ecosystems. In this context, short-time variability in the components of TMFs' $\mathrm{C}$ balance as a result of local climate variation still needs to be resolved if we want to assess the possible impact of global climate changes on $\mathrm{C}$ fluxes in TMFs or the degree of the expected $\mathrm{C}$ fertilization effect of increasing atmospheric $\mathrm{CO}_{2}$ on NPP. 


\subsection{References}

Bendix J, Rollenbeck R, Richter M, Fabian P, Emck P (2008) The altitudinal gradient climate. In: Gradients in a tropical mountain ecosystem of Ecuador. (eds.: Beck E, Bendix J, Kottke I, Makeschin F, Mosandl R). Springer Verlag, Berlin, Germany. Ecological Studies 198, in press.

Brujinzeel LA, Veneklaas EJ (1998) Climatic conditions and tropical montane forest productivity: The fog is not lifted yet. Ecology 79, 3-9.

Cavaleri MA, Oberbauer SF, Ryan MG (2006) Wood $\mathrm{CO}_{2}$ efflux in a primary tropical rain forest. Global Change Biology 12, 2442-2458.

Cavaleri MA, Oberbauer SF, Ryan MG (2008) Foliar and ecosystem respiration in an oldgrowth tropical rain forest. Plant Cell and Environment (online early article) 1-11.

Chambers JQ, Tribuzy ES, Toledo LC, Crispim BF, Higuchi N, Dos Santos J, Araújo AC, Kruijt B, Nobre AS, Trumbore SE (2004) Respiration from a tropical forest ecosystem: Partitioning of sources and low carbon use efficiency. Ecological Applications 14, 72-88.

Fearnside PM (1997) Greenhouse gases from deforestation in Brazilian Amazonia: net committed emission. Journal of Climate Change 35, 321-360.

Godbold D L, Hoosbeek M R, Lukac M, Cotrufo M F, Janssens I A, Ceulemans R, Polle A, Velthorst E F, Scarascia-Mugnozza G, De Angelis P, Miglietta F, Peressotti A (2006) Mycorrhizal hyphal turnover as a dominant process for carbon input into soil organic matter. Plant and Soil 281, 15-24.

Grayston SJ (1997) Rhizosphere carbon flow in trees, in comparison with annual plants: the importance of root exudation and its impact on microbial activity and nutrient availability. Journal of Applied Soil Ecology 5, 29-56.

Iost S (2007) Soil respiration, microbial respiration and mineralization in soils of montane rainforests of southern Ecuador: influence of altitude. PhD Thesis, TU Dresden, Germany, pp. 171.

Larcher W (1998) Physiological plant ecology. Springer Verlag Berlin, Germany, pp. 513.

Leuschner C, Moser G, Bertsch C, Röderstein M, Hertel D (2007) Large altitudinal increase in the tree root/shoot ratio in tropical mountain forests of Ecuador. Basic and Applied Ecology 8, 219-230.

Luyssaert S, Inglima I, Jung M, Richardson AD, Reichstein M, Papale D, Piao SL, Schulze ED, Wingate L, Matteucci G, Aragao L, Aubinet M, Beer C, Bernhofer C, Black KG, Bonal D, Bonnefond FM, Chambers J, Ciais P, Cook B, Davis KJ, Dolman AJ, Gielen B, Goulden M, Grace J, Granier A, Grelle A, Griffis T, Grünwald T, Guidolotti G, Hanson PJ, Harding R, Hollonger DY, Hutyra LR, Kolari P, Kruijt B, Kutsch W, Lagergen F, Laurila T, Law BE, LeMaire G, Lindroth A, Loustau D, Malhi Y, Mateus J, Migliavacca M, Misson L, Montagnani L, Moncrieff J, Moors E, Munger, Nikinmaa E, Ollonger SV, Pita G, Rebmann C, Roupsard O, Saigusa N, Sanz MJ, Seufert G, Sierra C, Smith ML, Tang J, Valentini R, Vesala T, Janssens IA (2007) $\mathrm{CO}_{2}$ balance of boreal, temperate, and tropical forests derived from a global database. Global Change Biology 13, 2509-2537.

Maier TA, Zarnoch SJ, Dougherty PM (1998) Effects of temperature and tissue nitrogen on dormant season stem and branch respiration in a young loblolly pine (Pinus tadea) plantation. Tree Physiology 18, 11-20. 
Malhi Y, Baldocchi DD, Jarvis PG (1999) The carbon balance of tropical, temperate and boreal forests. Plant Cell and Environment 22, 715-740.

Malhi Y, Grace J (2000) Tropical forests and atmospheric carbon dioxide. Tree 15, 332-336.

Maraun M, Illig J, Sandman D, Krashevskaya V, Norton RA, Scheu S (2008) Soil fauna. In: Gradients in a tropical mountain ecosystem of Ecuador. (eds.: Beck E, Bendix J, Kottke I, Makeschin F, Mosandl R). Springer Verlag, Berlin, Germany. Ecological studies 198, in press.

Meir P, Grace J (2002) Scaling relationship for woody tissue respiration in two tropical rain forests. Plant, Cell and Environment 25, 963-973.

Mercado L, Lloyd J, Carswell F, Malhi Y, Meir P, Nobre AD (2006) Modelling Amazonian forest eddy covariance data: a comparison of big leaf versus sun/shade models for the C14 tower at Manaus. I. Canopy photosynthesis. Acta Amazonica 36, 69-82.

Moser G, Hertel D, Leuschner C (2007) Altitudinal change in LAI and stand leaf biomass in tropical montane forests: a transect study in Ecuador and a pan-tropical meta-analysis. Ecosystems 10, 924-935.

Moser G, Röderstein M, Graefe S, Soethe N, Hertel D, Leuschner C (submitted) Fine and coarse root dynamics of tropical montane forests along an altitudinal transect in southern Ecuador. Plant and Soil.

Moser G (2008) Elevation effects on key processes of carbon cycling in South Ecuadorian mountain forests. PhD Thesis. University of Göttingen, Germany, pp.125.

Penning de Vries FWT (1975) Use of assimilates in higher plants. In: Photosynthesis and productivity in different environments. (ed: Cooper JG). Cambrigde University Press, Cambridge, pp. 459-480.

Ryan MG, Hubbard RM, Clark DA, Sanford RL Jr (1994) Woody-tissue respiration of Simarouba amara and Minquartia guinensis, two wet forest trees with different growth habits. Oecologia 100, 213-220.

Ryan MG, Gower ST, Hubbard RM, Waring RH, Gholz HL, Cropper WP, Running SW, (1995) Woody tissue maintenance respiration of four conifers in contrasting climates. Oecologia 101, 133-140.

Ryan MG, Hubbard RM, Pongracic S, Raison RJ, McMurtie RE (1996) Foliage, fine-root, woody-tissue and stand respiration in Pinus radiata in relation to nitrogen status. Tree Physiology 16, 333-343.

Sprugel DG, Benecke U (1991) Measuring woody-tissue respiration and photosynthesis. In: Techniques and approaches in forest tree ecophysiology (eds. Lassoie JP, Hinckley T) pp. 329-355. CRC-Press Inc, Boston.

Veneklaas EJ, Poorter L (1998) Growth and carbon partitioning of tropical tree seedlings in contrasting light environments. In: Inherent variation in plant growth. Physiological mechanisms and ecological consequences (eds. Lambers H, Poorter H, Van Vuren MMI), Backhuys Publishers, Leiden, pp. 337-355. 


\section{Chapter}

6

\section{SYNTHESIS}




\subsection{Discussion of hypotheses}

In Chapter 1, a number of hypotheses were introduced concerning altitudinal patterns in the $\mathrm{CO}_{2}$ release from above- and belowground plant organs to be tested in this study. The present section aims to discuss these hypotheses with respect to the previously described results and recent findings. The four hypotheses were as follows:

(i) Apparent $\mathrm{CO}_{2}$ release from stems increases with increasing elevation from $1050 \mathrm{~m}$ to $3050 \mathrm{~m}$.

(ii) Apparent $\mathrm{CO}_{2}$ release from coarse roots increases with increasing elevation from $1050 \mathrm{~m}$ to $3050 \mathrm{~m}$.

(iii) Apparent $\mathrm{CO}_{2}$ release rates from stems and coarse roots of tropical montane forests (TMF) at different elevation levels remain constant through the year and do not show seasonality.

(iv) With increasing elevation, woody tissue respiration shows an increasing relevance in the carbon balance of TMFs. At high elevations, maintenance respiration from stems and growth respiration from roots are predominant.

Previous intensive studies on above- and belowground biomass production found that with increasing elevation an increasing proportion of the available carbon (C) was translocated below the ground. While the aboveground annual biomass increment decreased 4.2-fold from 1050 to $3050 \mathrm{~m}$, the annual C allocation to the root system increased 4.2-fold from the premontane $(1050 \mathrm{~m})$ to the upper montane forest $(3050 \mathrm{~m})$. This enormous shift in the relative importance of above- to belowground plant organs should have been reflected in the respiratory activity of the respective plant organs. Mean annual rates of stem respiration (based on the bark surface area) declined 4.5-fold from 1050 to $3050 \mathrm{~m}$, while coarse root respiration decreased only by a factor of 2.2. The dissimilar decline in stem and coarse root respiration with increasing elevation resulted in a very similar level of respiratory activity of stems and coarse roots at the upper montane site, indicating the higher relative importance of belowground organs at higher altitudes (Chapter 2). Since absolute root biomass increased with increasing altitude, the extrapolation of coarse root respiration to the stand finally yielded a similar amount of $\mathrm{C}$ losses from the coarse root biomass at 1050 and $3050 \mathrm{~m}$. Annual stem wood C losses at the stand-level, in turn, showed the same 4.5-fold decline as found at tree-level as a result of the parallel decline in the aboveground biomass with increasing altitude. We therefore reject hypothesis (i) and accept hypothesis (ii). 
Hypothesis (i) was initially based on the assumption of a stress-induced compensatory $\mathrm{CO}_{2}$ release counterbalancing an assimilatory carbon gain which was assumed to be similar to the $\mathrm{CO}_{2}$ fixation at lower altitudes. In fact, annual C gain declined from 1050 to $3050 \mathrm{~m}$. On the other hand, this decline was mainly a function of the lower leaf area index (LAI) at high elevations accompanied by several less favourable abiotic conditions (e.g., low light intensity, temperature, nutrient availability), whereas the photosynthetic capacity of single leaves did not change significantly along the elevation transect (Chapter 5). At $3050 \mathrm{~m}$, a proportionally high $\mathrm{C}$ allocation to below the ground despite of a lower $\mathrm{C}$ gain compared to the lowerelevated sites can only be guaranteed at the expense of aboveground growth and hence aboveground respiration. We found no indication for a generally higher aboveground respiration at $3050 \mathrm{~m}$ as a result of abiotic stress throughout the year. However, the role of abiotic factors in driving the respiratory $\mathrm{CO}_{2}$ release from tree stems could not be resolved satisfactorily (Chapter 3) - leading to hypothesis (iii).

Respiration of a certain tissue type is commonly expected to increase strongly with increasing temperature. This response is more strongly related to variations in tissue temperature than to changes in ambient air temperature (Chapter 3). In a prevailing humid climate of TMFs, where seasonality is usually less pronounced and mean monthly air temperature, and hence tissue temperature fluctuates little throughout the year, we hypothesized that the respiratory activity of stems and coarse roots remain more or less constant through the year. Taking advantage of an exceptional dry season period within the 1year-measurement cycle we could show clear seasonal patterns in the respiratory $\mathrm{CO}_{2}$ release of stems, though not of coarse roots, along the elevation gradient (Chapter 4). Highest rates of stem respiration were found under the drier and warmer conditions of the dry season period at all three study sites, whereas measurements during the more humid periods yielded much lower stem $\mathrm{CO}_{2}$ release rates. Root respiration was less responsive as a result of minor fluctuations in the abiotic conditions (temperature, relative humidity, vapour pressure deficit) at the buffered environment of the soil surface where coarse roots were measured. Based on our findings we can prove a climate-sensitivity of stem respiration along the elevation transect that leads us to reject hypothesis (iii).

On the other hand, higher rates of stem respiration could not be simply related to temperature alone, rather we proposed that a complex interaction of several climate factors (light incidence, vapour pressure deficit, wind speed, soil water availability) might play a role in controlling plant respiratory activity (Chapter 3). Even more challenging is the remaining uncertainty with respect to the underlying mechanisms driving stem respiration to augment 
under dry season conditions. Stem cell growth in various tree species of the study area has been found to cease when soil water availability drops below a certain threshold during the dry season. In this context, we were not able to conclusively relate higher rates of stem respiration to higher cambial activity. On the contrary, the possibility exists that the higher respiratory activity might indeed be stress-induced resulting in an increasing release of $\mathrm{CO}_{2}$ via the less productive alternative pathway of respiration, with plant growth being unaffected. A decline in net primary production despite higher $\mathrm{CO}_{2}$ efflux under higher temperatures has been frequently observed for tropical lowland forests during the last decades. Higher rates of $\mathrm{CO}_{2}$ release without implications for the biomass increment under warmer climate conditions would have marked consequences for the atmospheric $\mathrm{CO}_{2}$ accumulation over tropical biomes under the expected global climate change.

Based on hypothesis (i) and (ii), we initially assumed that the shift in the relative importance of above- and belowground plant components with elevation should be reflected in the carbon balance of the TMFs and hypothesized that at higher elevations, maintenance respiration from stems and growth respiration from roots are predominant. We indeed found the fraction of coarse root growth respiration to increase markedly from 1050 to $3050 \mathrm{~m}$ (Chapter 4). On the other hand, the proportional partitioning between stem growth and stem maintenance respiration changed only slightly with increasing altitude, resulting in comparatively low fractions of stem growth respiration at the three sites than values found in the literature. Considering the entire $C$ balance of the three TMFs, a shift in the relevance of above- versus belowground plant organs could not be found (Chapter 5). The proportion of $\mathrm{C}$ available for the belowground components (i.e., the proportion of $\mathrm{C}$ allocated to the roots as percentage of total $\mathrm{CO}_{2}$ fixation) did not increase with increasing elevation as it would be expected in order to maintain a higher below- than aboveground biomass and biomass production at $3050 \mathrm{~m}$. Our first estimate of above- and belowground C partitioning at the three TMFs indicated that the belowground production might have been overestimated to a certain extent, at least at the upper montane site. However, our $C$ balances were not complete and some estimates of $\mathrm{C}$ balance components were based on very simple assumptions. In this regard, additional and more exact investigations are still needed until hypothesis (iv) can be conclusively answered, especially with respect to the total assimilatory $\mathrm{C}$ gain, the respiratory $\mathrm{CO}_{2}$ release from twigs and branches or from sunlit and shaded leaves, and the belowground biomass production. 


\subsection{Concluding remarks}

Measuring the respiratory $\mathrm{CO}_{2}$ release from stems and coarse roots was a convenient tool to reproduce patterns of above- and belowground C allocation of the three Andean moist forests. Furthermore, the organ-level $\mathrm{CO}_{2}$ efflux measurements could be used to quantify whole tree as well as stand-level C losses; though existing up scaling methods still lack standardization, which hampers comparison of literature data.

The impact of altitude and climatic fluctuations on the respiratory activity of woody plant organs studied at the level of single trees offered additional insight into the diverse response patterns of different tree species in a species-rich tropical forest community. However, the importance of diverging adaptation strategies of species and the affect of species origin warrant further investigation if we are to better understand species co-existence in the current and future structure of highly diverse tropical ecosystems. Such information would be particularly crucial with respect to global warming expecting to force mesic lowland taxa to migrate upwards in the tropics. In this context, tropical montane forests are of particular relevance and the portable chamber technique was shown to provide a suitable framework to assess species-specific patterns of woody tissue $\mathrm{CO}_{2}$ release to changes in climatic conditions in logistically difficult montane regions.

The highly differing climate-sensitivity found for the measured tree species already indicated that the present forest structure and functionality of tropical montane forests could be strongly affected by global climate change. A better understanding of plant respiratory responses towards warmer conditions is therefore challenging. 


\section{Chapter}

7

SUMMARY 


\subsection{Summary}

Tropical montane forests (TMF), which account for $21.2 \%$ of tropical forests worldwide, are among the least studied ecosystems with respect to their $C$ balance. TMFs are mainly characterized by high atmospheric humidity and frequent cloudiness driving the structure and functionality of these highly diverse ecosystems across a large altitudinal extension. One of the most marked changes with increasing elevation is the shift in $\mathrm{C}$ allocation from above- to belowground plant organs leading to a considerable decline in average tree height towards higher altitudes. Information on the key processes controlling the plant internal $\mathrm{C}$ use, the assimilatory $\mathrm{C}$ gain and the respiratory $\mathrm{CO}_{2}$ loss from single plant organs, is missing.

The present study aimed to quantify $\mathrm{CO}_{2}$ losses from above- and belowground woody organs of representative tree species of a tropical montane moist forest in southern Ecuador. Moreover, we wanted to extrapolate rates of woody tissue respiration to the stand level and bring them in the frame of a carbon balance. We used a portable $\mathrm{CO}_{2}$ measurement system to monitor the respiratory $\mathrm{CO}_{2}$ release from stems $\left(\mathrm{R}_{\mathrm{S}}\right)$ and coarse roots $\left(\mathrm{R}_{\mathrm{R}}\right)$ along a $2000 \mathrm{~m}$ elevation transect with three study sites at 1050, 1890 and 3050 m a.s.l. In an intensive 1year-measurement period we determined the impact of altitude and of seasonal climate variations on patterns of $\mathrm{CO}_{2}$ release from woody organs. We found substantial variation in the stem respiratory activity among different species and different tree individuals at all three study sites. Mean $\mathrm{R}_{\mathrm{S}}$ declined significantly from the premontane forest (1050 $\left.\mathrm{m}\right)$ to the upper montane site (3050 m). Mean $R_{R}$ did not change significantly with altitude, though showing a decreasing tendency. The results corroborated the remarkable shift in the relative importance of above- to belowground plant organs with increasing altitude as it has already been found for the biomass allocation patterns along the elevation gradient.

Temperature has long been known to be the most important abiotic driver of plant respiration. In the field, however, a consistent relationship between temperature and respiratory $\mathrm{CO}_{2}$ efflux is often not found. Comparing dry and wet season patterns in stem $\mathrm{CO}_{2}$ release we found $R_{S}$ to be largely uncoupled from changes in the dial temperature regime under humid season conditions. During the dry season, the respiration-temperature relationship was generally stronger, though temperature sensitivity of $R_{S}$ differed greatly in degree and even in the direction of response among individual trees. Integrating additional influencing abiotic factors (vapour pressure deficit, wind speed and solar radiation) could not enhance the ability to explain the variability of $\mathrm{R}_{\mathrm{S}}$. We assumed maintenance respiration to 
dominate under humid conditions unfavourable for photosynthetic carbon gain of the tree, whereas the dry season conditions principally favoured stem respiratory activity, and most likely energy acquisition. Differences in species distribution centres and hence in the level of climatic adaptation of co-existing moist forest tree species could provide an alternative tool to explain diverging temperature responses of $\mathrm{R}_{S}$ during the dry season.

Information about seasonal patterns of woody tissue $\mathrm{CO}_{2}$ release from evergreen tropical montane trees has received little attention. We found $R_{S}$, but not $R_{R}$ to show a clear seasonality within the measurement year. Highest rates were measured during the dry season, though the increase in $R_{S}$ could not be simply related to changes in the temperature regime. On the other hand, the high degree of climate sensitivity of $R_{S}$ of the studied montane forest trees could also indicate C losses via the alternative pathway (cyanide-resistant oxidase), since the higher respiratory activity could not satisfactorily be related to stimulated cell growth. Along the elevation transect, annual carbon efflux from stems decreased from $167.1 \mathrm{~g}$ $\mathrm{C} \mathrm{m}^{-2} \mathrm{yr}^{-1}$ at $1050 \mathrm{~m}$ to $37.7 \mathrm{~g} \mathrm{C} \mathrm{m}^{-2} \mathrm{yr}^{-1}$ at $3050 \mathrm{~m}$, while coarse root carbon release changed

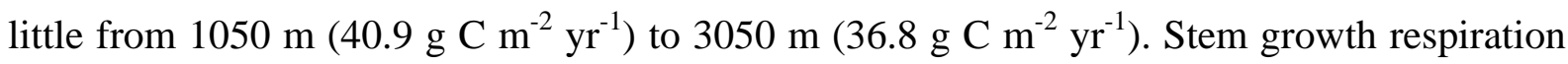
accounted for a comparatively small fraction of total stem respiration at all three sites, whereas coarse root growth respiration was of increasing importance with increasing altitude.

A first $\mathrm{C}$ balance of the three study sites confirmed the expected decline in the total canopy carbon gain from premontane to upper montane forests. However, with respect to the altitudinal changes in above- and belowground $\mathrm{C}$ allocation patterns, discrepancies between flux measurements and direct biomass assessments emerged. The enormous $\mathrm{C}$ translocation to the root system at $3050 \mathrm{~m}$ as previously found could not be matched by the amount of $\mathrm{C}$ available as derived from $\mathrm{C}$ influx and efflux estimates. On the other hand, the $\mathrm{C}$ balances were incomplete and uncertainties still exist with regard to the magnitude of important flux components such as the canopy $\mathrm{C}$ gain and the canopy respiratory $\mathrm{C}$ losses (including branches and twigs).

\subsection{Zusammenfassung}

Die Bergregenwälder der Tropen bedecken etwa 21.2 \% der Fläche tropischer Wälder weltweit; im Hinblick auf ihre Kohlenstoff-(C)-Bilanz gehören sie dennoch zu den am wenigsten untersuchten terrestrischen Ökosystemen. Die Struktur und Funktionalität tropischer Bergregenwälder wird über weite Flächen- und Höhenausdehnungen vorwiegend geprägt durch vergleichsweise hohe atmosphärische Feuchtigkeit und häufige 
Wolkenbedeckung. Eine der markantesten Veränderungen mit zunehmender Meereshöhe stellt die vermehrte Verlagerung von Kohlenstoff von oberirdischen zu unterirdischen Pflanzenorganen dar, welche in eine beachtliche Abnahme der durchschnittlichen Baumhöhe mit zunehmender Meereshöhe resultiert. Informationen über die Schlüsselprozesse der internen C-Nutzung der Pflanze, der assimilatorische C-Gewinn und der respiratorische CVerlust einzelner Pflanzenorgane fehlen weitestgehend.

Die vorliegende Arbeit hat zum Ziel, die respiratorischen Kohlenstoffdioxid- $\left(\mathrm{CO}_{2}\right)-$ Verluste verholzter ober- und unterirdischer Pflanzenorgane repräsentativer Baumarten in einem tropischen Bergregenwald im Süden Ecuadors zu quantifizieren. Weiterhin sollten CAbgaberaten verholzter Organe auf Bestandesebene hochgerechnet werden und in eine CBilanz eingebunden werden. Mit Hilfe einer tragbaren $\mathrm{CO}_{2}-\mathrm{Messapparatur}$ wurde entlang eines 2000-m-Höhentransektes an drei Untersuchungsflächen auf 1050, 1890 und 3050 m üNN die respiratorische $\mathrm{CO}_{2}$-Abgabe von Stämmen und Grobwurzeln gemessen. In einer intensiven 1-Jahres-Messkampagne wurde der Einfluss der Meereshöhe und der saisonalen Klimaunterschiede auf die respiratorische Aktivität der verholzten Organe untersucht. An allen drei Untersuchungsflächen wurde eine beträchtliche Variabilität in der Stammatmung zwischen den verschiedenen Baumarten und zwischen einzelnen Individuen gefunden. Die mittlere Stammatmung nahm mit zunehmender Höhe vom prämontanen $(1050 \mathrm{~m})$ zum hochmontanen (3050 m) Standort signifikant ab. Die mittlere Grobwurzelatmung verringerte sich mit zunehmender Meereshöhe zwar tendenziell, diese Veränderung war jedoch nicht signifikant. Somit bestätigen die vorliegenden Ergebnisse eine Verschiebung der relativen Wichtigkeit von oberirdischen zu unterirdischen Pflanzenorganen mit der Meereshöhe, wie sie bereits in vorangegangenen Studien zur Verlagerung der Biomasse mit zunehmender Meershöhe gefunden wurde.

Es ist seit langem bekannt, dass die Respiration der Pflanze vor allem durch die Temperatur als grössten abiotischen Einflussfaktor bestimmt wird. Jedoch konnte gerade im Feldversuch häufig keine konsistente Beziehung zwischen Temperatur und Atmung bestätigt werden. In einer vergleichenden Studie der Stammatmung unter Regen- und Trockenzeitbedingungen auf den Untersuchungsflächen wurde während der Regenzeit eine weitestgehende Entkopplung der Atmung von Veränderungen im täglichen Temperaturverlauf festgestellt. Unter Trockenzeitbedingungen war der Temperaturbezug der Atmung generell stärker ausgeprägt, jedoch fanden sich grosse Unterschiede in der Temperatursensitivität der einzelnen Baumindividuen im Hinblick auf Ausprägung und Richtung der Temperaturantwort. Auch unter Einbezug weiterer einflussnehmender abiotischer Faktoren 
(Sättigungsdefizit der Luft, Wind, Strahlung) konnte die Variabilität der Stammatmung nicht erklärt werden. Es wurde daher schlussfolgernd angenommen, dass unter den strahlungsextensiven und damit assimilationshemmenden Witterungsverhältnissen der Regenzeit die Erhaltungsatmung dominiert. Dahingegen scheint unter strahlungsgünstigen, und daher assimilationsfördernden Witterungsbedingungen der Trockenzeit die respiratorische Aktivität angeregt $\mathrm{zu}$ werden. Weiterhin könnten Unterschiede im Verbreitungsschwerpunkt einzelner Arten und daraus folgende Unterschiede in Adaptionsmechanismen einen alternativen Erklärungsansatz für die grosse Variabilität in der Temperaturantwort der Atmung co-existierender Baumarten unter extremen Trockenzeitbedingungen bieten.

Saisonale Unterschiede in der $\mathrm{CO}_{2}$-Abgabe von verholztem Gewebe tropischer immergrüner Baumarten wurde bislang wenig untersucht. Im Verlauf der einjährigen Messkampagne wurde eine stark ausgeprägte Saisonalität der Stammatmung, jedoch nicht der Wurzelatmung gefunden. Die höchsten Stamm $\mathrm{CO}_{2}$-Abgaberaten wurden während der Trockenzeit gemessen, jedoch konnten die erhöhten Atmungsraten nicht ausschliesslich auf die höhere Umgebungstemperatur zum Messzeitpunkt zurückgeführt werden. Vielmehr könnte die erhöhte Atmungsaktivität auch einen Hinweis auf C-Verluste über die alternative Oxidase (cyanidresistente Oxidase) liefern, da die erhöhte Respiration nicht überzeugend mit stimuliertem Zellwachstum in Verbindung gebracht werden konnte. Entlang des Höhentransektes nahm die jährliche C-Abgabe der Stämme von $167.1 \mathrm{~g} \mathrm{C} \mathrm{m}^{-2} \mathrm{yr}^{-1}$ auf 1050 m zu $37.7 \mathrm{~g} \mathrm{C} \mathrm{m}^{-2} \mathrm{yr}^{-1}$ auf $3050 \mathrm{~m}$ ab, wohingegen sich die jährliche C-Abgabe der Grobwurzeln im Höhenverlauf von 1050 m (40.9 g C m$\left.^{-2} \mathrm{yr}^{-1}\right)$ auf 3050 m (36.8 g C m $\mathrm{yr}^{-1}$ ) wenig änderte. Die Wachstumsatmung der Stämme nahm nur einen vergleichsweise geringen Anteil der Gesamtatmung ein, wohingegen die Wachstumsatmung der Grobwurzeln mit zunehmender Meereshöhe an Wichtigkeit gewann.

Eine erste Gesamt-C-Bilanz der drei Bergregenwald-Standorte bestätigte die erwartete Abnahme des assimilatorischen C-Gewinns von der prämontanen zur hochmomtanen Untersuchungsfläche. Im Hinblick auf die Veränderungen in der ober- und unterirdischen CVerlagerung mit zunehmender Meereshöhe zeigten sich jedoch Diskrepanzen zwischen der direkten Bestimmung der Biomasse und der indirekten Berechnung über gemessene C-Flüsse. Die enorme C-Verlagerung zum Wurzelsystem, wie sie in vorausgegangen Studien ermittelt wurde, konnte quantitativ nicht durch die ein- und ausgehenden C-Flüsse bestätigt werden. Jedoch ist zu beachten, dass die aufgestellten C-Bilanzen nicht vollständig sind und dass weiterhin grosse Unsicherheiten bestehen im Hinblick auf die Quantität der C-Flüsse 
wichtiger Komponenten wie etwa der C-Gewinn und -Verlust des Kronendaches (inklusive der Äste und Zweige).

\subsection{Resumen}

Los bosques tropicales montanos (TMF), cubren el 21.2\% de los bosques tropicales a nivel mundial, sin embargo son uno de los ecosistemas menos investigados especialmente con respecto a su balance de carbono. TMFs se caracterizan primeramente por la alta humedad atmosférica y la frequente nubosidad costituyendo los factores que determinan la estructura y funcionamiento de este ecosistema de diversidad complexa y amplia distribución altitudinal. Uno de los cambios más remarcables con el aumento de altitud es la redistribución de C entre los órganos aéreos y subterráneos, conduciendo a una reduccción considerable en la estatura de los árboles que crecen a mayores elevaciones. En general, existe muy poca información sobre los procesos clave en las plantas que controlan la asimilación de C y su emisión a través de la actividad respiratoria de diferentes órganos. El presente estudio tuvó como objetivo la cuantificación de las pérdidas de $\mathrm{CO}_{2}$ a través de los troncos $\left(\mathrm{R}_{\mathrm{S}}\right)$ y de las raíces gruesas $\left(\mathrm{R}_{\mathrm{R}}\right)$ de especies de árboles representativas del bosque tropical montano húmedo del sur de Ecuador. Para las medidas de $\mathrm{CO}_{2}$ usamos un sistema portátil de intercambio de gases y monitoreamos las emisiones de $\mathrm{CO}_{2}$ de troncos y raíces gruesas a lo largo de un transecto de 2000 m-de elevación y en tres localidades ubicadas a 1050, 1890 y 3050 m s.n.m. Durante el periodo de un año, llevamos a cabo medidas intensivas para determinar el impacto del cambio altitudinal y variación climática estacional en los patrones de emisión de $\mathrm{CO}_{2}$ de diferentes órganos leñosos.

En cada una de las tres localidades estudiadas encontramos considerable variación en la actividad respiratoria de troncos entre las diferentes especies e individuos seleccionados. La tasa promedio de emisión de $\mathrm{CO}_{2}$ de los troncos $\left(\mathrm{R}_{\mathrm{S}}\right)$ disminuyó significativamente del bosque premontano (1050 m) al bosque montano alto (3050 m). La tasa promedio de emisión de $\mathrm{CO}_{2}$ de las raíces gruesas $\left(R_{R}\right)$ no mostro variación altitudinal significativa, sin embargo se pudo observar una tendencia decreciente. Los resultados de este estudio corroboran el cambio remarcable en la importancia relativa de los órganos aéreos con respecto a los órganos subterráneos de árboles del bosque tropical montano con el aumento altitudinal. Tal cambio ha sido reportado previamente mediante observaciones sobre los patrones de distribución de biomasa a lo largo del mismo gradiente altitudinal. 
La temperatura ha sido siempre identificada como el factor abiotico más importante responsable por la variación en las tasas de respiración. Sin embargo, en el campo, no siempre es possible encontrar una relación consistente entre la temperatura y las tasas de emisión de $\mathrm{CO}_{2}$. Mediante la comparación de los patrones de emisión de $\mathrm{CO}_{2}$ de los troncos durante las estaciones húmeda y seca, observamos que $\mathrm{R}_{\mathrm{S}}$ no respondió a los cambios del regimén diario de temperatura bajo las condiciones de la estación húmeda. Durante la estación seca, la relación repiración-temperatura fue más fuerte, aunque la sensibilidad de $R_{S}$ fué altamente variable en magnitud e incluso en la dirección de la respuesta. Aún con la adición de información sobre la variación de otros factores abióticos, (deficit de presión de vapor de agua, dirección del viento y radiación solar), no se logro obtener una mejor estimación para los valores de $\mathrm{R}_{\mathrm{S}}$. Bajo condiciones húmedas, poco favorables para la actividad fotosintética de asimilacion de carbono, se puede asumir que la respiración de mantenimiento domina la tasa total de emisión de $\mathrm{CO}_{2}$. Mientras que condiciones secas con alta radiación y temperatura favorecen la actividad respiratoria y adquisición de energía. Diferencias en los centros de distribución y consecuentemente en la adaptación climática de especies arbóreas podrían proporcionar una herramienta alternativa para explicar la divergencia en la respuesta de $R_{S}$ a las variaciones en temperatura durante la época seca.

En las investigaciones de especies arbóreas del bosque tropical montano, se ha dado poca atención al estudio de los patrones estacionales de emisión de $\mathrm{CO}_{2}$ de la biomasa leñosa. En este estudio y durante el periodo de un año de observacion se pudo identificar una clara variabilidad estacional en $R_{S}$, pero no en $R_{R}$. Las tasas más altas de emisión de $\mathrm{CO}_{2}$ fueron registradas durante la época seca, aunque el aumento en $R_{S}$ no pudo ser relacionado únicamente a cambios en temperatura. Por otro lado, el alto grado de sensibilidad climática de $\mathrm{R}_{\mathrm{S}}$ de los árboles del bosque montano estudiado podrían indicar pérdida de $\mathrm{C}$ por medio de ciclos vanos, ya que la tasa más alta de actividad respiratoria no pudo ser relacionada satisfactoriamente con una estimulación del crecimiento a nivel celular. A lo largo del transecto altitudinal, la emisión anual de carbono de los troncos disminuyó de167.1 g C m ${ }^{-2}$ ${ }^{1}$ a $1050 \mathrm{~m}$ a $37.7 \mathrm{~g} \mathrm{C} \mathrm{m}^{-2} \mathrm{a}^{-1}$ a $3050 \mathrm{~m}$, mientras que la emisión anual de las raíces gruesas se mantuvo constante entre $1050 \mathrm{~m}\left(40.9 \mathrm{~g} \mathrm{C} \mathrm{m}^{-2} \mathrm{a}^{-1}\right)$ y $3050 \mathrm{~m}\left(36.8 \mathrm{~g} \mathrm{C} \mathrm{m}^{-2} \mathrm{a}^{-1}\right)$. La respiración de crecimiento de los troncos constituyó una fraccion mínima de la tasa total de emisión de los troncos en las tres elevaciones. A nivel de raíces gruesas, la fracción correspondiente a la respiración de crecimiento mostró un incremento con la altitud.

Un primer balance de $\mathrm{C}$ de los tres sitios confirmó una disminución en la tasa neta de asimilación de carbono del bosque premontano al bosque montano alto. Sin embargo, con 
respecto a los cambios altitudinales en los patrones de distribución de $\mathrm{C}$ entre la biomasa aérea y subterránea, diferentes discrepancias emergieron entre las estimaciones de flujo de C basadas en medidas de asimilación de $\mathrm{CO}_{2}$ y las estimaciones basadas en medidas de biomasa. La asignación de grandes cantidades de carbono al sistema radicular a $3050 \mathrm{~m}$ observada en previas investigaciones, no pudo ser explicada por la cantidad de C disponible de acuerdo a nuestras estimaciones del balance entre el flujo de C. Por otro lado, se debe tener en cuenta que nuestro balance de $\mathrm{C}$ no esta completo ya que todavía se tienen muchas incertidumbres sobre la magnitud e importancia de componentes importantes del flujo de C, como es el caso de la asimilación y pérdida de C en el dosel (incluyendo ramas gruesas y finas). 


\section{Chapter}

8

APPENDIX 
Appendix 1. Species list of the measured tree stems at 1050, 1890 and $3050 \mathrm{~m}$ a.s.l. Some trees could not be determined to species level (indet). Given are DBH $(\mathrm{cm})$ at the beginning (August 2005) and end (September 2006) of the measurement campaigns, tree height (tree, m; G. Moser) and clear bole length (bole, m; own measurements).

\begin{tabular}{|c|c|c|c|c|c|c|}
\hline Abbr. & Species & Family & $\begin{array}{l}\text { DBH } \\
2005\end{array}$ & $\begin{array}{l}\text { DBH } \\
2006\end{array}$ & tree & bole \\
\hline & $1050 \mathrm{~m}$ & & & & & \\
\hline An1 & indet & Annonaceae & 10.05 & 10.47 & 9.90 & 5.8 \\
\hline An2 & indet & Annonaceae & 21.37 & 21.53 & 14.50 & 9.2 \\
\hline Sc1 & Schefflera sp. & Araliaceae & 27.67 & 27.74 & 18.80 & 9.6 \\
\hline Pou & Pourouma cf. & Cecropiaceae & 14.32 & 14.65 & 13.40 & 9.9 \\
\hline $\mathrm{Al}$ & Alchornea sp. & Euphorbiaceae & 8.75 & 9.3 & 13.30 & 5.7 \\
\hline La1 & indet & Lauraceae & 13.66 & 13.67 & 12.30 & 9.9 \\
\hline La2 & indet & Lauraceae & 17.07 & 17.07 & 11.90 & 10.7 \\
\hline Mp1 & Miconia punctata & Melastomataceae & 9.8 & - & 14.04 & \\
\hline Mp2 & Miconia punctata & Melastomataceae & 11.93 & 12.03 & 10.51 & 10.5 \\
\hline Mp3 & indet & Melastomataceae & 15.35 & 15.53 & 11.80 & 5.2 \\
\hline In & Inga sp. & Mimosaceae & 16.34 & 16.41 & 17.80 & 10.5 \\
\hline Mi & indet & Mimosaceae & 10.08 & 10.1 & 18.10 & 13.3 \\
\hline Fi1 & Ficus sp. & Moraceae & 14.16 & - & 16.20 & 5 \\
\hline Fi2 & Ficus sp. & Moraceae & 14.64 & 14.64 & 14.20 & 9.9 \\
\hline Fi3 & Ficus sp. & Moraceae & 16.03 & 16.43 & 14.20 & 13.1 \\
\hline Fi4 & Ficus sp. & Moraceae & 43.85 & 43.99 & 29.90 & 11.85 \\
\hline $\mathrm{Vi}$ & Virola $\mathrm{cf}$. & Myristicaceae & 14.17 & 14.17 & 15.00 & 12 \\
\hline Myt & indet & Myrtaceae & 10.96 & 11.1 & 11.20 & 8.95 \\
\hline $\mathrm{Ch}$ & Chrysophyllum sp. & Sapotaceae & 8.84 & 9.08 & 11.20 & 7.6 \\
\hline Po1 & Pouteria cf. & Sapotaceae & 20.79 & 20.78 & 16.80 & 11.1 \\
\hline Po2 & Pouteria cf. & Sapotaceae & 43.72 & 43.72 & 26.60 & 15 \\
\hline & $1890 \mathrm{~m}$ & & & & & \\
\hline Ia & Ilex amboroica & Aquifoliaceae & 9.63 & 9.64 & 7.50 & 5.65 \\
\hline Sc2 & Schefflera sp. & Araliaceae & 9.16 & - & 14.55 & 6.70 \\
\hline $\mathrm{Cr}$ & Clethra revoluta & Clethraceae & 23.45 & 23.65 & 12.69 & 4.98 \\
\hline $\mathrm{Hm}$ & Hyeronima moritziana & Euphorbiaceae & 9.52 & 9.53 & 13.70 & 8.24 \\
\hline Eo & Endlicheria oreocola & Lauraceae & 20.8 & 20.82 & 10.00 & 6.17 \\
\hline $\mathrm{Ne}$ & Nectandra sp. & Lauraceae & 11.64 & 11.71 & 12.45 & 1.60 \\
\hline $\mathrm{Oa}$ & Ocotea aciphylla & Lauraceae & 10.21 & 10.26 & 10.50 & 6.43 \\
\hline Ge1 & Graffenrieda emarginata & Melastomataceae & 24.91 & 25 & 17.40 & 10.54 \\
\hline Ge2 & Graffenrieda emarginata & Melastomataceae & 26.11 & 26.1 & 16.54 & 8.72 \\
\hline Ge3 & Graffenrieda emarginata & Melastomataceae & 26.47 & 26.5 & 19.82 & 8.18 \\
\hline Mp4 & Miconia punctata & Melastomataceae & 10.62 & 10.64 & 14.05 & 6.28 \\
\hline Mp5 & Miconia punctata & Melastomataceae & 12 & 12 & 7.06 & 12.14 \\
\hline Mp6 & Miconia punctata & Melastomataceae & 14.45 & 14.56 & 12.53 & 8.84 \\
\hline Мс & Myrsine coriacea & Myrsinaceae & 3.76 & 3.82 & 7.10 & 4.38 \\
\hline Lo & Ladenbergia oblongifolia & Rubiaceae & - & 12.14 & 9.70 & 4.10 \\
\hline $\mathrm{Pa}$ & Palicourea sp. & Rubiaceae & 3.02 & - & 3.70 & 2.14 \\
\hline Mi1 & Matayba inelegans & Sapindaceae & 4.46 & 4.5 & 5.60 & 3.92 \\
\hline Mi2 & Matayba inelegans & Sapindaceae & 8.17 & 8.25 & 8.30 & 4.20 \\
\hline Mi3 & Matayba inelegans & Sapindaceae & 10.53 & 10.67 & 12.70 & 6.50 \\
\hline Mg & Micropholis guyanensis & Sapotaceae & 8.35 & 8.46 & 7.80 & 4.60 \\
\hline
\end{tabular}




\begin{tabular}{lllrrrr}
\hline Abbr. & Species & Family & $\begin{array}{r}\text { DBH } \\
2005\end{array}$ & $\begin{array}{r}\text { DBH } \\
2006\end{array}$ & tree & bole \\
\hline & 3050 $\mathbf{~ m}$ & & & & & \\
Iw & Ilex weberlingii & Aquifoliaceae & 8.2 & 8.2 & 5.72 & 4.49 \\
He & Hedyosmum sp. & Chloranthaceae & 9.36 & 9.36 & 4.19 & 1.81 \\
Cl1 & Clusia sp.1 & Clusiaceae & 17.67 & 17.67 & 5.80 & 1.50 \\
Cl2 & Clusia sp.2 & Clusiaceae & 8.94 & 9.01 & 6.79 & 1.63 \\
Wl & Weinmannia loxensis & Cunoniaceae & 10.5 & 10.5 & 6.13 & 3.34 \\
Ce & Cerotostema cf. & Ericaceae & 3.6 & 3.61 & 3.74 & 1.93 \\
Er & indet & Ericaceae & 15.6 & 15.6 & 6.22 & 1.64 \\
Ax & Axinea sp. & Melastomataceae & 8.99 & 8.99 & 4.80 & 2.60 \\
Ma & Myrsine andina & Myrsinaceae & 9.55 & 9.55 & 7.74 & 1.27 \\
Mys & indet & Myrsinaceae & 3.92 & 3.92 & 4.80 & 2.87 \\
Mo & Monnina sp. & Polygalaceae & 2.48 & 2.58 & 3.51 & 2.32 \\
Sf & Styrax foveolaria & Styracaceae & 12.06 & 12.08 & 3.43 & 1.71 \\
Sy & Symplocos sp. & Symplocaceae & 9.8 & 9.81 & 6.68 & 3.30 \\
& & & & & & \\
\hline
\end{tabular}


Appendix 2. The mobile 6-chamber respiration system ANARESY 2 (Walz, Effeltrich, Germany) with measurement equipment at one of the study sites (1050 m) (top left); tree stem respiration chamber with bark surface temperature sensor on the left hand side of the chamber at the study site at $1890 \mathrm{~m}$ (top right); coarse root respiration chamber with bark surface temperature sensor (mid left) and a coarse root tissue temperature sensor (bottom left). The author and a portable infrared gas analyzer (Li-6400, Li-Cor, Inc.) at $1050 \mathrm{~m}$ (bottom right).

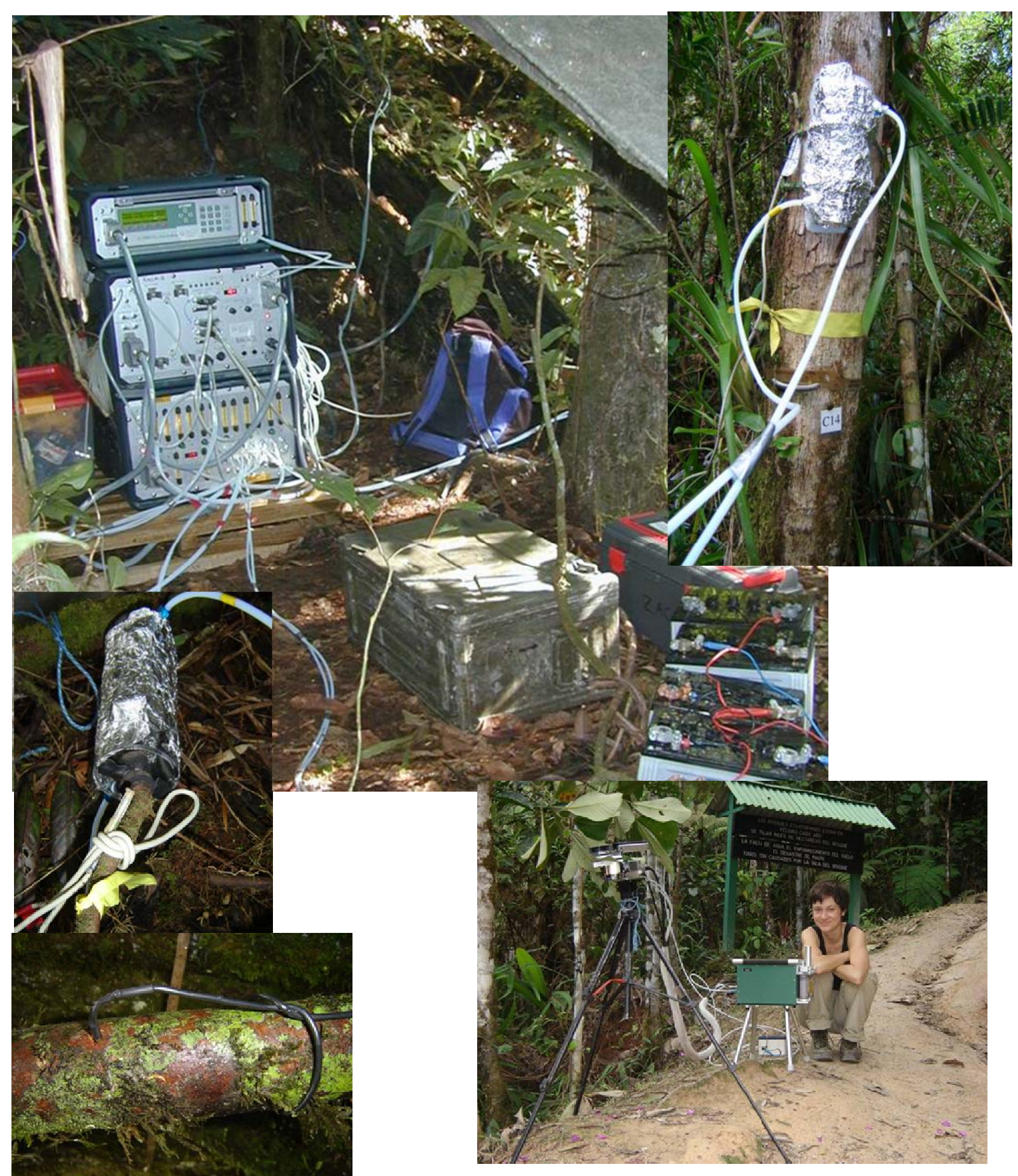




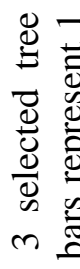

충 은

四完

원 웅

등

ไี ฮิ

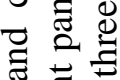

밀

层

凷

葛. 范

ธี ลิํㅝㄹ

उ 듄

正

彗密

ธี 능

吕递

茪

吾完

马्

ชิ

路

वे

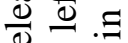

กิ่

U

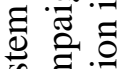

के 言.

is

岂 苋

$0 \%$

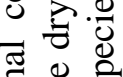

苞 के

คి

लึ 寻

m

永

훈

交总
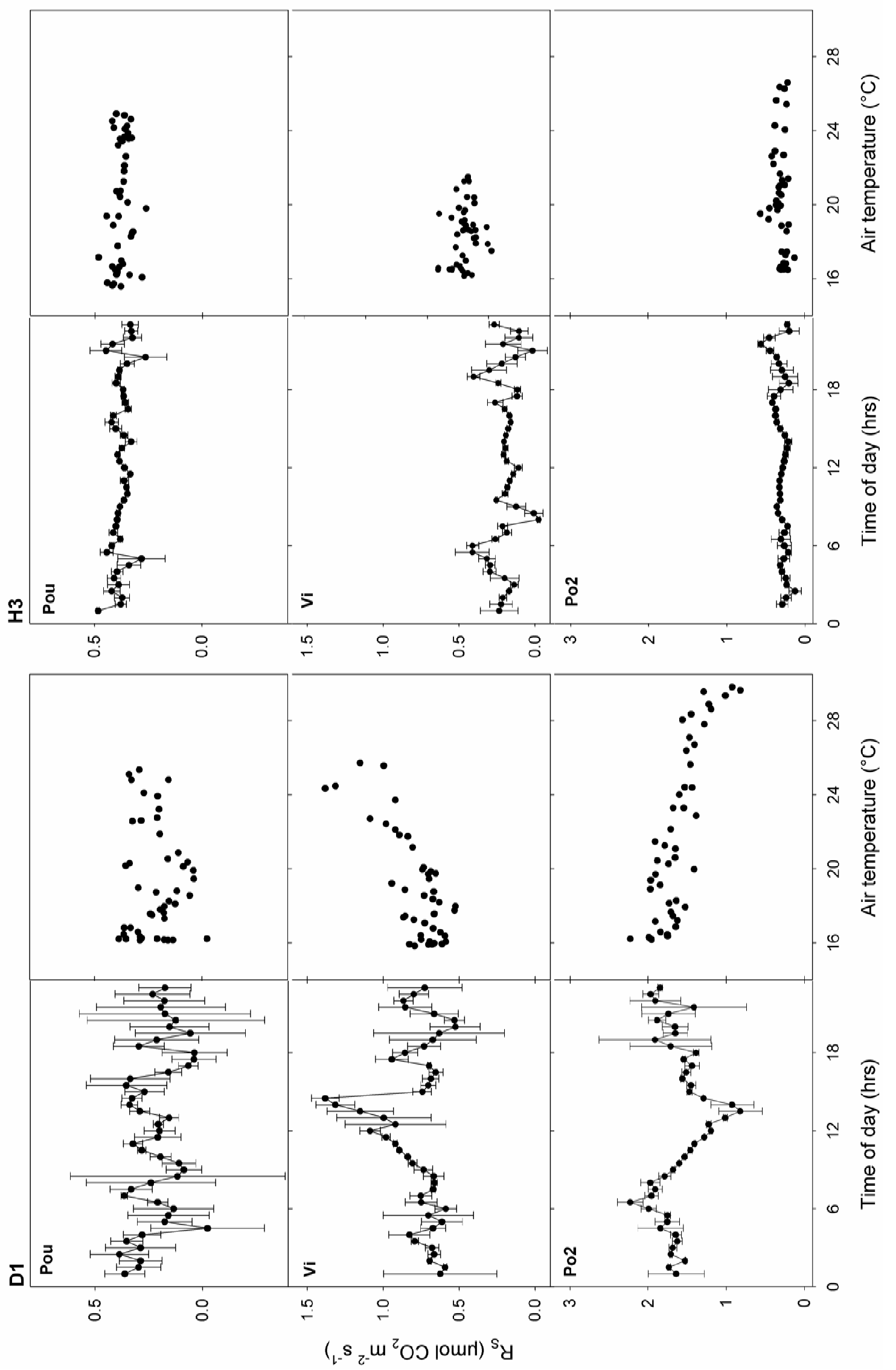


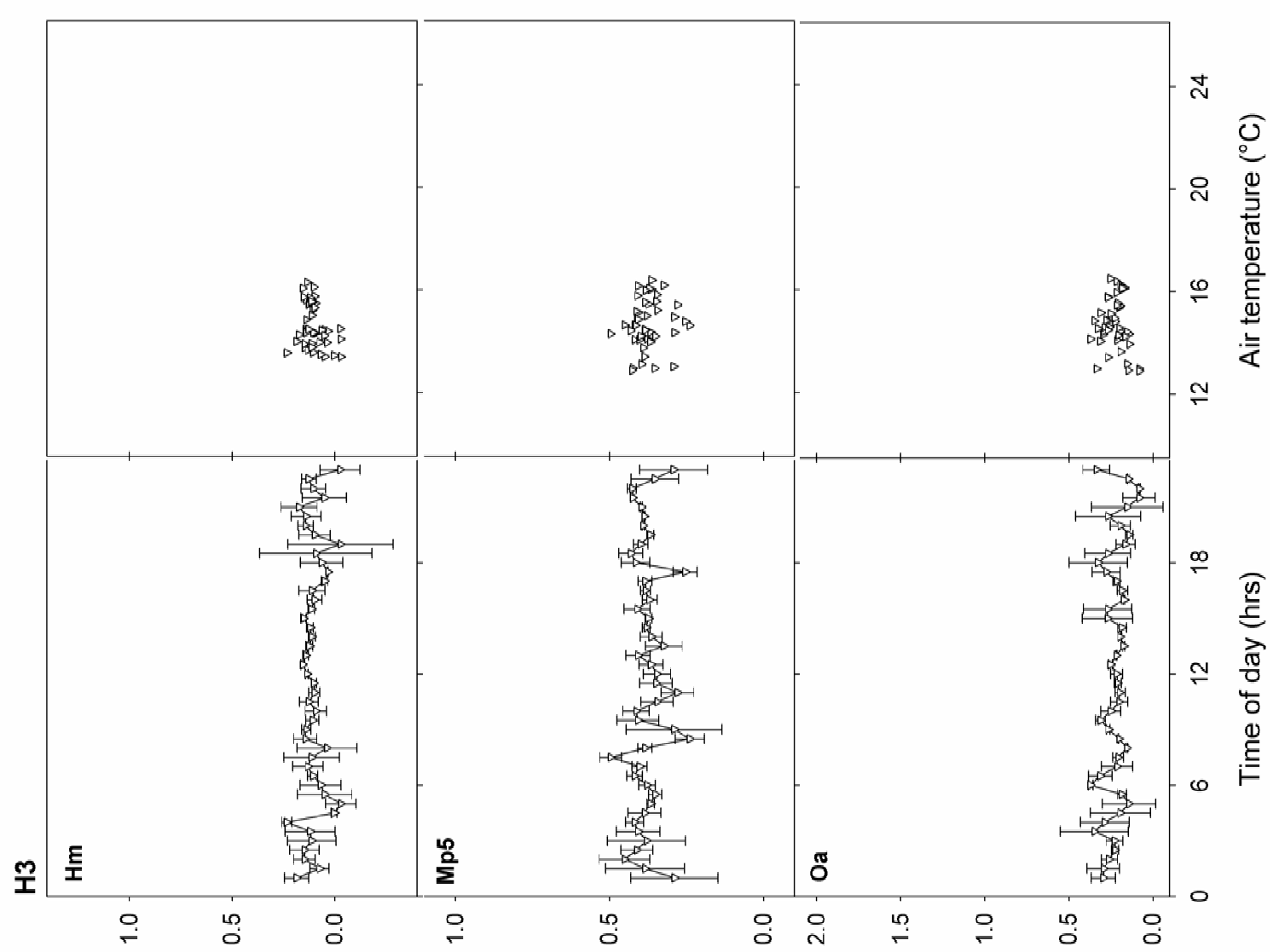

记寻积

气ิ

营聶总

$\Phi 00$

悬。

్ㅠ 밈

ชิฮ

) สี

蛋

의

กิ)

O

․․․

के 范

प च

ธี

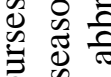

ช

즌

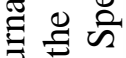

官

寉宣

ले

물

完空

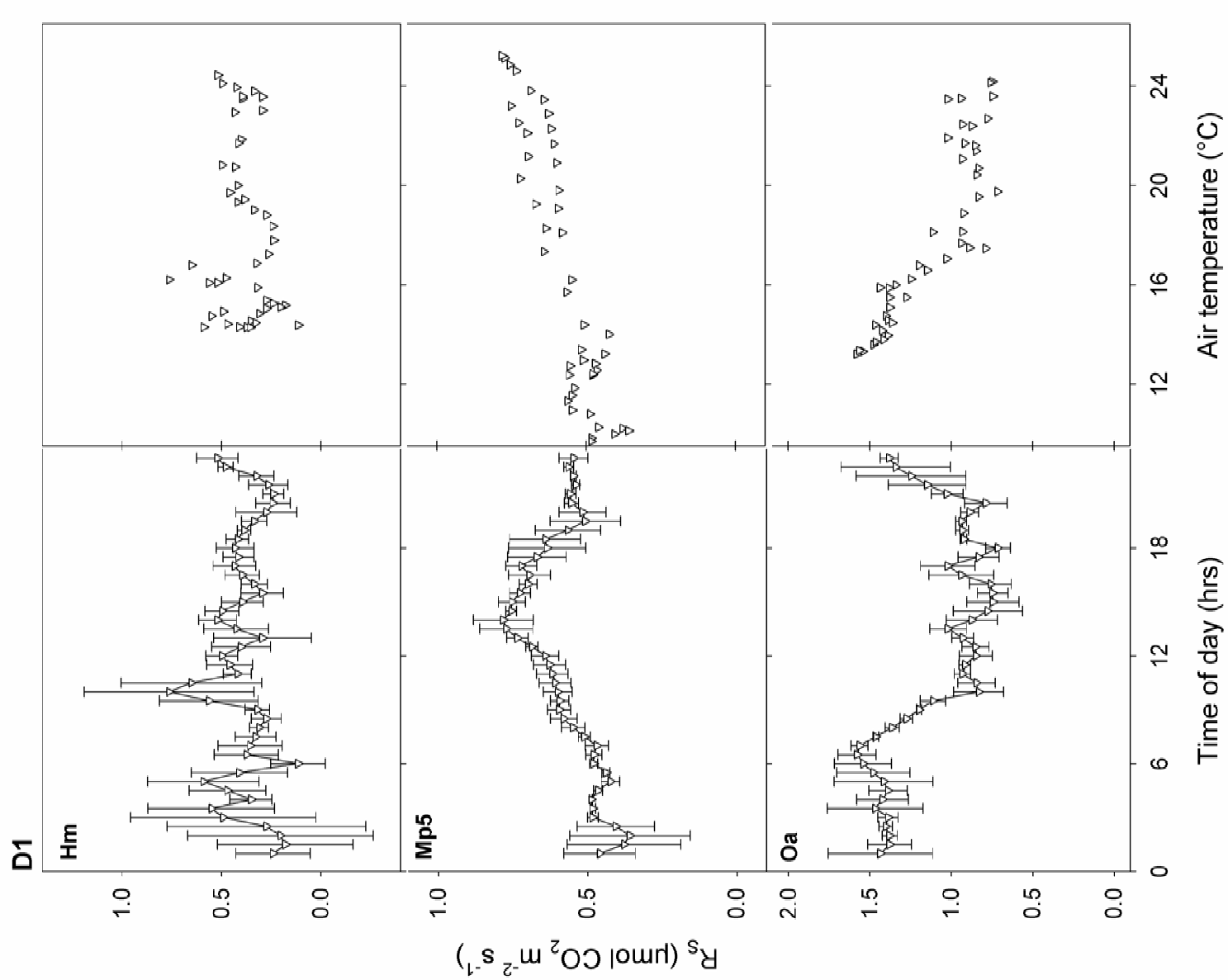



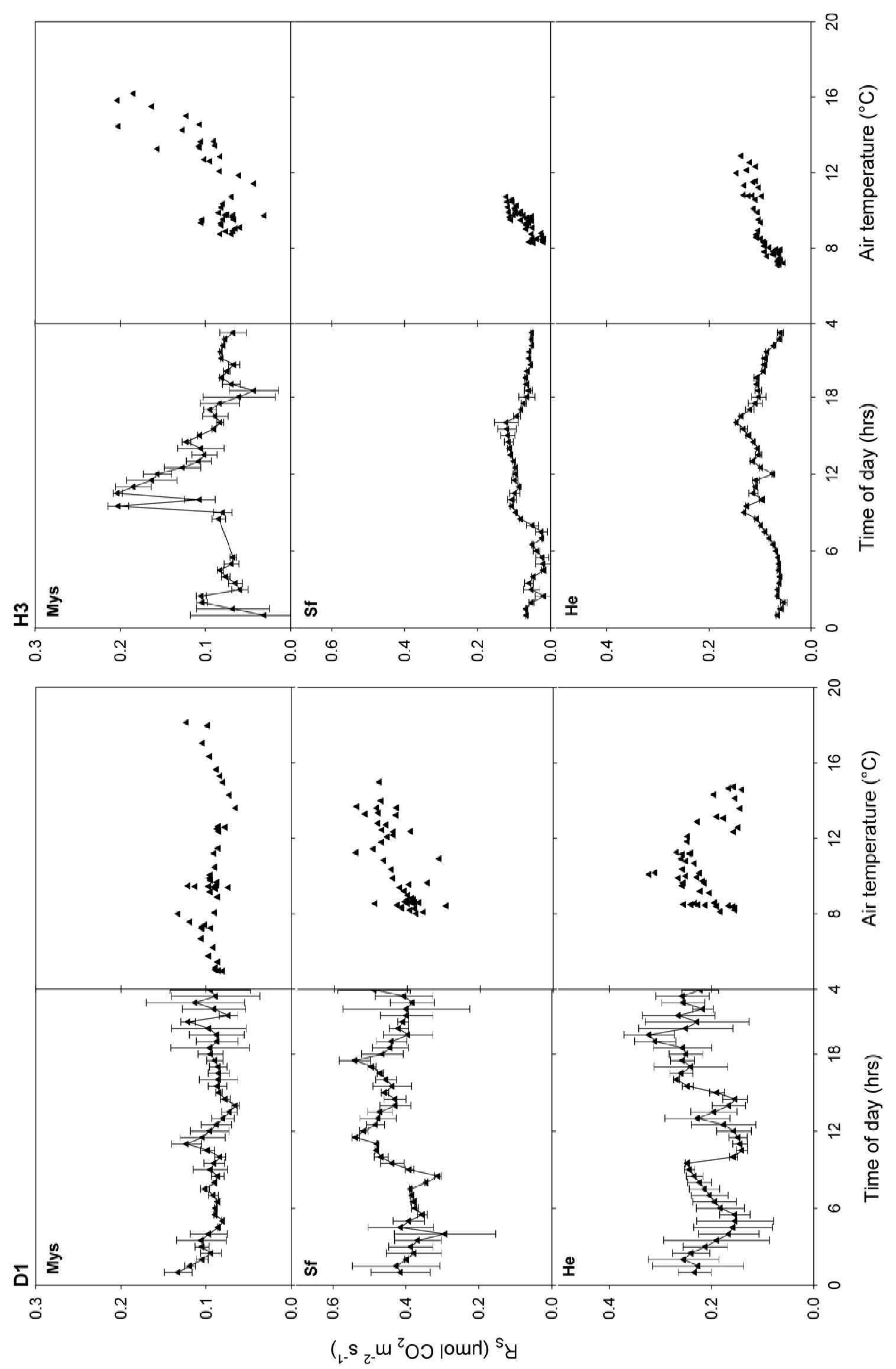
Appendix 4. Contents of carbon and nitrogen and mineral concentrations ( $\mathrm{mg} \mathrm{g}^{-1}$ ) of wood cores from the measured tree stems of the three sites at 1050, 1890 and $3050 \mathrm{~m}$ elevation. See Appendix 1 for species abbreviation. Coarse roots are described by their diameter $(\mathrm{d}, \mathrm{cm})$.

\begin{tabular}{|c|c|c|c|c|c|c|c|}
\hline & C & $\mathrm{N}$ & $\mathrm{Ca}$ & $\mathrm{K}$ & $\mathrm{Na}$ & $\mathrm{Mg}$ & $\mathrm{P}$ \\
\hline \multicolumn{8}{|l|}{ Stems } \\
\hline \multicolumn{8}{|l|}{$1050 \mathrm{~m}$} \\
\hline An1 & 88.08 & 0.42 & 0.81 & 3.79 & 0.06 & 0.30 & 0.18 \\
\hline An2 & 91.28 & 0.50 & 0.64 & 3.13 & -0.04 & 0.31 & -0.27 \\
\hline Sc1 & 97.53 & 0.60 & 1.18 & 2.63 & 0.00 & 0.29 & -0.09 \\
\hline Pou & 89.21 & 0.40 & 1.33 & 1.96 & 0.00 & 0.70 & -0.09 \\
\hline $\mathrm{Al}$ & 77.49 & 0.37 & 1.44 & 2.22 & -0.02 & 0.70 & -0.18 \\
\hline La1 & 88.91 & 0.54 & 0.79 & 0.71 & -0.05 & 0.07 & -0.26 \\
\hline $\mathrm{La} 2$ & 87.82 & 0.59 & 2.54 & 1.65 & -0.04 & 0.14 & 0.00 \\
\hline \multicolumn{8}{|l|}{ Mp1 } \\
\hline Mp2 & 88.61 & 0.54 & 0.97 & 3.37 & -0.04 & 0.65 & -0.44 \\
\hline Mp3 & 79.48 & 0.49 & 2.33 & 2.45 & -0.02 & 0.18 & -0.27 \\
\hline In & 89.39 & 0.67 & 1.24 & 2.89 & -0.05 & 0.02 & -0.44 \\
\hline $\mathrm{Mi}$ & 94.33 & 0.65 & 2.26 & 4.04 & -0.02 & 0.19 & -0.26 \\
\hline Fi1 & 85.96 & 0.35 & 2.12 & 9.16 & 0.01 & 0.63 & 0.35 \\
\hline $\mathrm{Fi} 2$ & 83.50 & 0.43 & 1.97 & 2.74 & 0.05 & 0.28 & -0.09 \\
\hline Fi3 & 88.69 & 0.38 & 5.09 & 6.64 & -0.03 & 3.39 & -0.18 \\
\hline Fi4 & 94.83 & 1.14 & 1.60 & 1.30 & -0.02 & 0.17 & -0.09 \\
\hline $\mathrm{Vi}$ & 89.15 & 0.64 & 1.77 & 1.74 & 0.00 & 0.23 & -0.35 \\
\hline Myt & 83.47 & 0.33 & 2.09 & 2.23 & 0.05 & 0.76 & -0.27 \\
\hline $\mathrm{Ch}$ & 90.50 & 0.58 & 0.72 & 3.16 & -0.05 & 0.27 & -0.35 \\
\hline Po1 & 89.49 & 0.69 & 0.44 & 1.43 & -0.03 & 0.14 & -0.09 \\
\hline Po2 & 104.14 & 0.82 & 0.44 & 1.04 & 0.01 & 0.20 & 0.09 \\
\hline \multicolumn{8}{|l|}{$1890 \mathrm{~m}$} \\
\hline Ia & 89.96 & 0.26 & 0.52 & 1.92 & 0.02 & 0.60 & 0.09 \\
\hline Sc2 & 91.09 & 0.30 & 0.99 & 3.68 & 0.03 & 0.57 & 0.35 \\
\hline $\mathrm{Cr}$ & 82.69 & 0.21 & 0.69 & 1.69 & 0.03 & 0.33 & 0.26 \\
\hline $\mathrm{Hm}$ & 82.96 & 0.26 & 0.25 & 0.98 & -0.03 & 0.11 & 0.27 \\
\hline Eo & 91.76 & 0.72 & 0.38 & 1.73 & -0.02 & 0.15 & 0.35 \\
\hline $\mathrm{Ne}$ & 91.05 & 0.47 & 0.25 & 1.34 & -0.03 & 0.15 & 0.26 \\
\hline $\mathrm{Oa}$ & 89.68 & 0.41 & 0.00 & 0.86 & -0.04 & 0.07 & 0.35 \\
\hline Ge1 & 93.89 & 0.27 & 0.31 & 1.49 & 0.00 & 0.21 & 0.26 \\
\hline Ge2 & 81.86 & 0.29 & 0.04 & 1.30 & 0.17 & 0.17 & 0.18 \\
\hline Ge3 & 80.82 & 0.23 & 0.34 & 1.20 & 0.00 & 0.14 & 0.00 \\
\hline Mp4 & 91.07 & 0.44 & 0.46 & 3.30 & 0.00 & 0.39 & 0.00 \\
\hline Mp5 & 91.67 & 0.45 & 0.30 & 1.52 & 0.00 & 0.27 & 0.44 \\
\hline Mp6 & 91.68 & 0.45 & 0.26 & 2.27 & 0.04 & 0.26 & 0.18 \\
\hline Mc & 82.07 & 0.28 & 0.46 & 1.93 & 0.00 & 0.17 & 0.44 \\
\hline Lo & 94.88 & 0.35 & 0.22 & 2.09 & -0.02 & 0.15 & 0.35 \\
\hline $\mathrm{Pa}$ & 91.61 & 0.60 & 1.49 & 5.81 & 0.01 & 1.32 & 0.35 \\
\hline Mi1 & 77.70 & 0.43 & 0.14 & 2.96 & 0.00 & 0.32 & 0.35 \\
\hline Mi2 & 89.77 & 0.55 & 1.92 & 1.48 & -0.01 & 0.57 & 0.35 \\
\hline $\mathrm{Mi3}$ & 86.68 & 0.36 & 0.38 & 1.38 & 0.01 & 0.28 & 0.27 \\
\hline Mg & 83.25 & 0.46 & 0.50 & 0.85 & 0.01 & 0.17 & 0.53 \\
\hline
\end{tabular}




\begin{tabular}{|c|c|c|c|c|c|c|c|}
\hline & $\mathrm{C}$ & $\mathrm{N}$ & $\mathrm{Ca}$ & $\mathrm{K}$ & $\mathrm{Na}$ & $\mathrm{Mg}$ & $\mathrm{P}$ \\
\hline \multicolumn{8}{|c|}{$3050 \mathrm{~m}$} \\
\hline Iw & 93.02 & 0.27 & 0.72 & 1.93 & 0.04 & 0.94 & 0.26 \\
\hline $\mathrm{He}$ & 84.64 & 0.23 & 0.35 & 1.62 & 0.00 & 0.28 & 0.26 \\
\hline Cl1 & 80.22 & 0.17 & 0.79 & 1.72 & 0.06 & 0.70 & 0.26 \\
\hline $\mathrm{Cl} 2$ & 79.57 & 0.15 & 0.65 & 1.30 & 0.01 & 0.16 & 0.26 \\
\hline Wl & 86.97 & 0.18 & 1.04 & 2.67 & 0.52 & 0.72 & 0.27 \\
\hline $\mathrm{Ce}$ & 92.22 & 0.22 & 0.69 & 1.61 & -0.06 & 0.33 & 0.09 \\
\hline Er & 84.30 & 0.16 & 1.39 & 2.70 & 0.01 & 0.42 & 0.18 \\
\hline \multicolumn{8}{|l|}{$A x$} \\
\hline Мa & 92.05 & 0.20 & 0.26 & 1.54 & 0.00 & 0.14 & 0.18 \\
\hline Mys & 90.91 & 0.20 & 0.59 & 1.61 & 0.05 & 0.27 & 0.26 \\
\hline Mo & 76.55 & 0.25 & 0.31 & 2.44 & 0.02 & 0.18 & 0.18 \\
\hline Sf & 88.94 & 0.19 & 0.55 & 1.25 & 0.01 & 0.20 & 0.26 \\
\hline Sy & 86.02 & 0.31 & 0.65 & 1.93 & 0.02 & 0.27 & 0.09 \\
\hline \multicolumn{8}{|c|}{ Roots } \\
\hline \multicolumn{8}{|c|}{ d } \\
\hline \multicolumn{8}{|c|}{$1050 \mathrm{~m}$} \\
\hline 1.1 & 110.3 & 2.68 & 7.42 & 2.16 & 0.04 & 0.22 & 0.53 \\
\hline 1.4 & 122.2 & 3.71 & 4.20 & 3.73 & 0.08 & 0.33 & 0.53 \\
\hline 1.7 & 151.1 & 2.32 & 1.06 & 1.23 & 0.00 & 0.50 & 0.44 \\
\hline 2.0 & 152.4 & 2.17 & 1.36 & 3.86 & -0.01 & 0.37 & 0.44 \\
\hline 2.5 & 128.0 & 1.57 & 11.90 & -0.56 & 0.12 & 1.50 & 0.26 \\
\hline 2.6 & 132.3 & 1.62 & 9.48 & 6.48 & -0.03 & 0.49 & 0.53 \\
\hline 3.0 & 103.4 & 1.38 & 8.50 & 4.09 & 0.13 & 0.77 & 0.53 \\
\hline 3.7 & 136.9 & 3.26 & 4.48 & 1.33 & 0.00 & 0.60 & 0.71 \\
\hline \multicolumn{8}{|c|}{$1890 \mathrm{~m}$} \\
\hline 1.3 & 143.1 & 3.01 & 0.72 & 1.86 & 0.00 & 0.33 & 0.53 \\
\hline 1.5 & 113.9 & 1.22 & 1.66 & 2.59 & -0.04 & 0.58 & 0.62 \\
\hline 1.6 & 113.6 & 0.85 & 0.53 & 1.85 & -0.05 & 0.42 & 0.70 \\
\hline 2.0 & 122.7 & 1.23 & 0.78 & 6.34 & -0.03 & 0.66 & 0.44 \\
\hline 2.2 & 139.7 & 1.61 & 0.58 & 2.02 & 0.00 & 0.27 & 0.53 \\
\hline 2.9 & 134.7 & 1.45 & 3.82 & 3.55 & -0.02 & 0.77 & 0.44 \\
\hline 3.0 & 122.4 & 1.54 & 0.66 & 2.59 & -0.03 & 0.31 & 0.53 \\
\hline \multicolumn{8}{|c|}{$3050 \mathrm{~m}$} \\
\hline 1.5 & 114.1 & 0.97 & 1.77 & 4.04 & 0.02 & 2.79 & 0.44 \\
\hline 1.8 & 125.4 & 1.07 & 6.01 & 5.49 & 0.00 & 1.02 & 0.53 \\
\hline 2.3 & 106.9 & 0.62 & 1.68 & 3.99 & -0.02 & 1.04 & 0.44 \\
\hline 2.9 & 130.4 & 0.80 & 0.30 & 0.74 & 0.00 & 0.15 & 0.18 \\
\hline
\end{tabular}


Appendix 5. Rates of $\mathrm{CO}_{2}$ release $\left(\mu \mathrm{mol} \mathrm{CO}_{2} \mathrm{~m}^{-2} \mathrm{~s}^{-1}\right)$ of the measured tree individuals and coarse roots (SD in parenthesis). Given are mean diurnal rates of $\mathrm{CO}_{2}$ efflux from each measurement campaigns (H1, D1, H2 and H3). At 1890 m one measurement campaign was done twice, during the first unusual dry part of April 2006 (H2dry) and when more typical rainy weather started two weeks later $\left(\mathrm{H}_{2}\right.$ wet). See Appendix 1 for species abbreviation. Coarse roots are described by their diameter $(\mathrm{d}, \mathrm{cm})$.

\begin{tabular}{|c|c|c|c|c|c|c|c|c|c|c|}
\hline & \multicolumn{2}{|l|}{ H1 } & \multicolumn{2}{|l|}{ D1 } & \multicolumn{2}{|l|}{$\begin{array}{r}\mathrm{H} 2 \\
\left(\mathrm{H} 2_{\mathrm{dry}}\right) \\
\end{array}$} & \multicolumn{2}{|l|}{$\mathrm{H} 2_{\text {wet }}$} & \multicolumn{2}{|l|}{ H3 } \\
\hline \multicolumn{11}{|c|}{ Stems } \\
\hline 1050 & & & & & & & & & & \\
\hline An1 & 1.02 & $(0.18)$ & 2.40 & $(0.47)$ & 0.63 & $(0.12)$ & & & 0.25 & $(0.07)$ \\
\hline An2 & & & 1.82 & $(0.13)$ & 0.78 & $(0.05)$ & & & 0.69 & $(0.07)$ \\
\hline Sc1 & 0.79 & $(0.14)$ & 2.18 & $(0.37)$ & 0.93 & $(0.12)$ & & & 0.80 & $(0.10)$ \\
\hline Pou & 0.63 & $(0.28)$ & 0.22 & $(0.10)$ & 0.29 & $(0.08)$ & & & 0.37 & $(0.04)$ \\
\hline $\mathrm{Al}$ & & & 0.41 & $(0.10)$ & 0.75 & $(0.13)$ & & & 0.41 & $(0.10)$ \\
\hline La1 & 0.27 & $(0.26)$ & 1.71 & $(0.33)$ & 0.38 & $(0.08)$ & & & 0.28 & $(0.08)$ \\
\hline La2 & & & 1.38 & $(0.25)$ & 0.29 & $(0.07)$ & & & 0.19 & $(0.05)$ \\
\hline Mp1 & 0.90 & $(0.19)$ & 0.41 & $(0.14)$ & & & & & & \\
\hline Mp2 & & & 1.65 & $(0.17)$ & 0.80 & (0.06) & & & 0.68 & $(0.15)$ \\
\hline Mp3 & 1.39 & $(0.13)$ & 0.84 & $(0.29)$ & 0.49 & $(0.08)$ & & & 0.73 & $(0.13)$ \\
\hline In & 1.06 & (0.19) & 0.34 & $(0.15)$ & 0.68 & $(0.13)$ & & & 0.88 & (0.09) \\
\hline Mi & 1.19 & $(0.21)$ & 1.32 & $(0.18)$ & 0.44 & $(0.09)$ & & & 0.58 & $(0.07)$ \\
\hline Fi1 & 0.44 & $(0.17)$ & 2.32 & $(0.51)$ & & & & & & \\
\hline Fi2 & 0.79 & $(0.17)$ & 0.49 & $(0.15)$ & 0.20 & $(0.06)$ & & & 0.08 & $(0.10)$ \\
\hline Fi3 & 0.66 & $(0.09)$ & 0.54 & $(0.12)$ & 1.14 & $(0.08)$ & & & 1.33 & $(0.14)$ \\
\hline Fi4 & 1.71 & $(0.25)$ & 2.71 & $(0.30)$ & 0.51 & $(0.09)$ & & & 0.37 & $(0.11)$ \\
\hline $\mathrm{Vi}$ & & & 0.78 & $(0.18)$ & 0.21 & $(0.08)$ & & & 0.20 & (0.09) \\
\hline Myt & 1.34 & $(0.14)$ & 1.00 & $(0.15)$ & 0.90 & $(0.06)$ & & & 1.00 & $(0.12)$ \\
\hline Ch & 1.40 & $(0.15)$ & 1.70 & $(0.20)$ & 0.31 & $(0.06)$ & & & 0.53 & $(0.07)$ \\
\hline Po1 & 1.17 & $(0.15)$ & 3.20 & (0.38) & 0.40 & $(0.09)$ & & & 0.67 & $(0.10)$ \\
\hline Po2 & 0.77 & $(0.22)$ & 1.60 & $(0.29)$ & 0.25 & $(0.08)$ & & & 0.30 & $(0.08)$ \\
\hline \multicolumn{11}{|c|}{$1890 \mathrm{~m}$} \\
\hline Ia & 0.12 & $(0.20)$ & 0.18 & $(0.11)$ & 0.40 & $(0.09)$ & & & 0.29 & $(0.06)$ \\
\hline Sc2 & -0.005 & $(0.11)$ & 0.11 & $(0.06)$ & & & 0.17 & $(0.17)$ & & \\
\hline $\mathrm{Cr}$ & 0.93 & $(0.15)$ & 0.99 & $(0.10)$ & 0.65 & $(0.08)$ & 0.42 & $(0.10)$ & 0.48 & $(0.11)$ \\
\hline $\mathrm{Hm}$ & 0.35 & $(0.10)$ & 0.39 & $(0.13)$ & 0.38 & $(0.21)$ & 0.24 & $(0.08)$ & 0.11 & $(0.06)$ \\
\hline Eo & 0.11 & $(0.08)$ & 0.87 & $(0.24)$ & 0.44 & $(0.16)$ & 0.15 & $(0.07)$ & 0.15 & $(0.08)$ \\
\hline $\mathrm{Ne}$ & & & 2.12 & $(0.33)$ & 1.70 & $(0.19)$ & 0.32 & $(0.09)$ & 1.05 & $(0.11)$ \\
\hline $\mathrm{Oa}$ & 0.53 & $(0.11)$ & 1.13 & $(0.27)$ & 1.68 & $(0.18)$ & 0.37 & $(0.07)$ & 0.19 & $(0.09)$ \\
\hline Ge1 & 0.73 & $(0.13)$ & 0.55 & $(0.14)$ & 0.51 & $(0.12)$ & 0.03 & $(0.07)$ & 0.03 & $(0.05)$ \\
\hline Ge2 & 0.74 & $(0.24)$ & 0.61 & $(0.18)$ & 1.21 & $(0.14)$ & 0.05 & $(0.13)$ & 0.19 & $(0.22)$ \\
\hline Ge3 & 0.22 & $(0.09)$ & 0.96 & $(0.08)$ & 0.31 & (0.09) & 0.14 & $(0.08)$ & 0.04 & $(0.03)$ \\
\hline Mp4 & 0.79 & $(0.33)$ & 1.34 & $(0.26)$ & 1.05 & $(0.10)$ & 0.52 & $(0.07)$ & 0.14 & $(0.04)$ \\
\hline Mp5 & & & 0.58 & $(0.11)$ & 1.02 & $(0.11)$ & 0.66 & $(0.11)$ & 0.38 & $(0.06)$ \\
\hline Mp6 & 0.17 & $(0.10)$ & 0.91 & $(0.13)$ & 0.97 & $(0.13)$ & 0.31 & $(0.07)$ & 0.23 & $(0.03)$ \\
\hline Мс & 0.02 & $(0.05)$ & 0.09 & $(0.07)$ & 0.00 & $(0.04)$ & 0.06 & $(0.05)$ & 0.06 & $(0.03)$ \\
\hline Lo & & & 0.28 & $(0.09)$ & 0.60 & $(0.12)$ & 0.19 & $(0.08)$ & 0.64 & $(0.09)$ \\
\hline $\mathrm{Pa}$ & 0.03 & $(0.07)$ & 0.18 & $(0.06)$ & 0.17 & $(0.05)$ & 0.17 & $(0.07)$ & & \\
\hline Mi1 & 0.18 & $(0.06)$ & 1.02 & $(0.21)$ & 0.59 & $(0.11)$ & & & 0.51 & $(0.12)$ \\
\hline Mi2 & 2.13 & $(0.22)$ & 0.85 & $(0.22)$ & 1.24 & $(0.17)$ & 0.40 & $(0.11)$ & 0.91 & $(0.13)$ \\
\hline Mi3 & 1.19 & $(0.20)$ & 1.04 & $(0.34)$ & 1.78 & $(0.42)$ & 0.64 & $(0.18)$ & 0.53 & $(0.07)$ \\
\hline Mg & 0.42 & $(0.11)$ & 1.06 & $(0.11)$ & 0.37 & $(0.11)$ & 0.29 & $(0.19)$ & 0.18 & $(0.06)$ \\
\hline
\end{tabular}




\begin{tabular}{|c|c|c|c|c|c|c|c|c|c|c|}
\hline & H1 & & D1 & & $\begin{array}{r}\mathrm{H} 2 \\
\left(\mathrm{H} 2_{\text {dry }}\right)\end{array}$ & & $\mathrm{H} 2_{\text {wet }}$ & & H3 & \\
\hline \multicolumn{11}{|l|}{$3050 \mathrm{~m}$} \\
\hline Iw & & & 0.22 & $(0.06)$ & 0.04 & $(0.03)$ & & & 0.12 & 0.02 \\
\hline Не & & & 0.22 & $(0.05)$ & 0.90 & $(0.08)$ & & & 0.09 & 0.02 \\
\hline Cl1 & & & 0.23 & $(0.05)$ & 0.02 & $(0.02)$ & & & 0.51 & 0.02 \\
\hline $\mathrm{Cl} 2$ & & & 0.03 & $(0.04)$ & -0.04 & $(0.03)$ & & & 0.24 & 0.04 \\
\hline Wl & & & 0.30 & $(0.05)$ & & & & & 0.14 & 0.02 \\
\hline $\mathrm{Ce}$ & & & 0.19 & $(0.06)$ & & & & & 0.20 & 0.03 \\
\hline Er & & & 0.11 & $(0.05)$ & 0.05 & $(0.05)$ & & & 0.02 & 0.01 \\
\hline$A x$ & & & 0.39 & $(0.06)$ & 0.26 & $(0.03)$ & & & 0.28 & 0.04 \\
\hline Ма & & & 0.11 & $(0.03)$ & 0.07 & $(0.03)$ & & & 0.02 & 0.01 \\
\hline Mys & & & 0.09 & $(0.01)$ & 0.09 & $(0.04)$ & & & & \\
\hline Mo & & & 0.19 & $(0.10)$ & 0.27 & $(0.04)$ & & & 0.05 & 0.02 \\
\hline Sf & & & 0.42 & $(0.05)$ & 0.27 & $(0.02)$ & & & 0.07 & 0.03 \\
\hline Sy & & & 0.28 & $(0.04)$ & 0.29 & $(0.10)$ & & & 0.18 & 0.03 \\
\hline \multicolumn{11}{|l|}{ Roots } \\
\hline \multirow{2}{*}{\multicolumn{11}{|c|}{$1050 \mathrm{~m}$}} \\
\hline & & & & & & & & & & \\
\hline 1.1 & 0.45 & $(0.24)$ & 0.37 & (0.15) & 0.40 & $(0.18)$ & & & 0.37 & $(0.17)$ \\
\hline 1.4 & 0.07 & $(0.32)$ & 0.76 & $(0.14)$ & 0.23 & $(0.15)$ & & & 0.30 & (0.15) \\
\hline 1.7 & 0.17 & (0.15) & 0.22 & $(0.12)$ & 0.10 & $(0.09)$ & & & 0.35 & $(0.09)$ \\
\hline 2.0 & 0.31 & (0.15) & 0.38 & (0.19) & 0.35 & $(0.09)$ & & & 0.43 & $(0.13)$ \\
\hline 2.5 & 0.73 & (0.19) & 0.09 & $(0.10)$ & & & & & & \\
\hline 2.6 & 0.48 & (0.13) & 0.47 & $(0.09)$ & 0.43 & $(0.14)$ & & & 0.39 & $(0.07)$ \\
\hline 3.0 & & & 0.31 & $(0.10)$ & 0.21 & $(0.06)$ & & & & \\
\hline 3.7 & 0.34 & (0.10) & 0.14 & $(0.05)$ & 0.82 & $(0.22)$ & & & & \\
\hline \multicolumn{11}{|l|}{$1890 \mathrm{~m}$} \\
\hline 1.3 & & & 0.15 & (0.13) & 0.12 & $(0.16)$ & 0.08 & $(0.14)$ & 0.05 & $(0.13)$ \\
\hline 1.5 & & & 0.50 & $(0.16)$ & 0.24 & $(0.12)$ & & & 0.46 & $(0.12)$ \\
\hline 1.6 & & & 0.07 & $(0.15)$ & & & & & & \\
\hline 2.0 & & & 0.14 & $(0.04)$ & 0.08 & $(0.07)$ & 0.15 & $(0.10)$ & 0.12 & $(0.05)$ \\
\hline 2.1 & & & 0.52 & $(0.07)$ & 0.15 & $(0.07)$ & 0.33 & $(0.15)$ & & \\
\hline 2.9 & & & 0.23 & $(0.08)$ & 0.15 & $(0.04)$ & 0.18 & $(0.08)$ & 0.18 & (0.06) \\
\hline 3.0 & & & 0.34 & $(0.06)$ & 0.78 & $(0.07)$ & 0.59 & $(0.12)$ & 0.42 & $(0.06)$ \\
\hline \multicolumn{11}{|l|}{$3050 \mathrm{~m}$} \\
\hline 1.5 & & & 0.11 & $(0.05)$ & 0.33 & $(0.07)$ & & & 0.17 & $(0.04)$ \\
\hline 1.8 & & & 0.36 & (0.11) & & & & & 0.02 & $(0.02)$ \\
\hline 2.3 & & & 0.28 & $(0.06)$ & 0.20 & $(0.04)$ & & & 0.28 & $(0.03)$ \\
\hline 2.9 & & & 0.06 & $(0.05)$ & 0.01 & $(0.04)$ & & & -0.02 & $(0.01)$ \\
\hline
\end{tabular}


Appendix 6. Diurnal courses of coarse root $\mathrm{CO}_{2}$ release $\left(\mathrm{R}_{\mathrm{R}}\right)$ from four selected root individuals measured during the dry season (D1) and during one of the more humid campaigns (H3) at the three study site at 1050, 1890 and $3050 \mathrm{~m}$. Error bars represent 1SD. $\mathrm{d}=$ diameter.
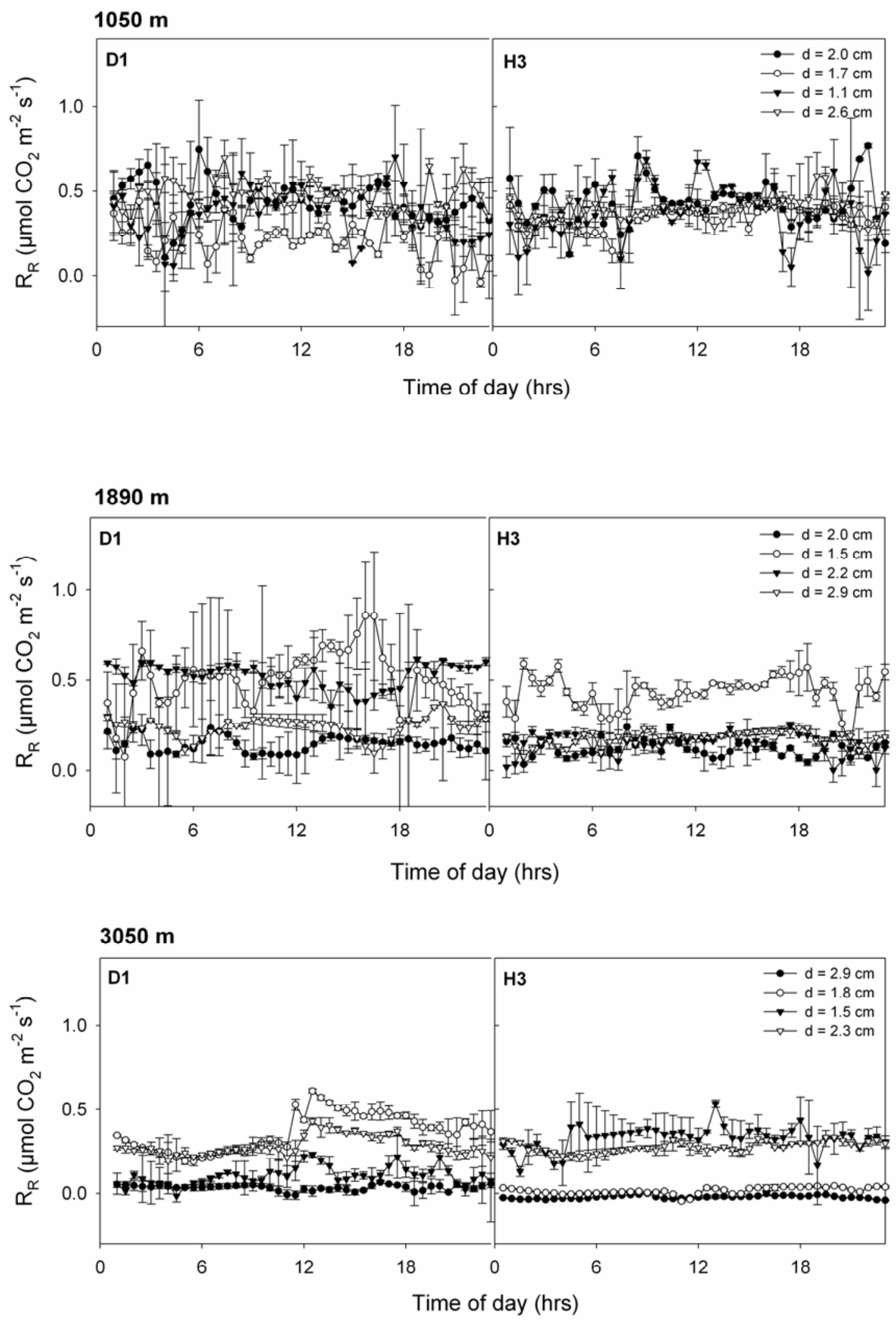
Appendix 7. Mean photosynthetic capacity $\left(\mathrm{A}_{\max }, \mu \mathrm{mol} \mathrm{CO}_{2} \mathrm{~m}^{-2}\right.$ leaf $\left.\mathrm{s}^{-1}\right)$, leaf nitrogen content ( $\left.\mathrm{mg} \mathrm{g}^{-1}\right)$ and $\mathrm{C} / \mathrm{N}$ ratio of measured leaves nearby the study sites at 1050, $1890 \mathrm{~m}$ and within the site at 3050 m elevation (SD in parenthesis). $n=$ number of leaves measured

\begin{tabular}{|c|c|c|c|c|c|c|}
\hline Species & Family & $\mathrm{n}$ & $A_{\max }$ & $\mathrm{N}$ & & $\mathrm{C} / \mathrm{N}$ \\
\hline \multicolumn{7}{|l|}{$1050 \mathrm{~m}$} \\
\hline indet & indet (Leguminoseae) & 3 & $5.09(0.73)$ & 8.82 & $(1.24)$ & 15.47 \\
\hline Lectandra $\mathrm{cf}$ & Lauraceae & 5 & $6.31(0.73)$ & 9.18 & $(0.79)$ & 15.78 \\
\hline Miconia sp & Melastomataceae & 4 & $8.31(2.49)$ & 4.37 & $(0.36)$ & 30.16 \\
\hline Psammisa cf & Ericaceae & 4 & 3.73 (1.37) & 2.57 & $(0.50)$ & 53.52 \\
\hline Hedyosmum sp & Chlorantaceae & 4 & $8.86(2.35)$ & 4.66 & $(0.34)$ & 27.89 \\
\hline indet & Myrtaceae & 4 & $6.58(1.78)$ & 4.45 & (0.19) & 29.78 \\
\hline Vismia sp & Clusiaceae & 4 & $7.83(1.08)$ & 3.56 & $(0.58)$ & 43.11 \\
\hline \multicolumn{7}{|l|}{$2000 \mathrm{~m}$} \\
\hline Cavendishia zamorensis & Ericaceae & 3 & $8.47(1.10)$ & 3.43 & $(0.03)$ & 46.24 \\
\hline Myrica pubescens & Myricaceae & 3 & $6.43(2.61)$ & 5.01 & $(0.61)$ & 26.37 \\
\hline indet & Asteraceae & 3 & $4.28(0.76)$ & 4.66 & $(0.24)$ & 29.42 \\
\hline \multicolumn{7}{|l|}{$3050 \mathrm{~m}$} \\
\hline Miconia & Melastomataceae & 4 & $5.98(0.85)$ & 4.15 & $(0.13)$ & 28.99 \\
\hline indet & Chlorantaceae & 3 & 3.84 (1.43) & 4.45 & $(0.52)$ & 27.36 \\
\hline indet & Cunnoniaceae & 1 & 1.76 & 3.26 & & 38.01 \\
\hline Faramea & Rubiaceae & 2 & $6.10(0.24)$ & 5.45 & $(0.43)$ & 21.67 \\
\hline indet & indet & 4 & $3.40(1.81)$ & 6.27 & $(2.65)$ & 26.36 \\
\hline Clusia sp1 & Clusiaceae & 3 & $4.36(1.84)$ & 3.19 & $(0.34)$ & 44.71 \\
\hline Axinea & Melastomataceae & 4 & $5.45(2.02)$ & 3.77 & $(0.46)$ & 37.87 \\
\hline indet & Melastomataceae & 1 & 5.97 & 2.84 & & 53.62 \\
\hline Cerotostema cf & Ericaceae & 2 & $3.92(1.82)$ & 2.58 & $(0.06)$ & 57.15 \\
\hline Styrax foveolaria & Stryracaceae & 3 & $8.69(2.70)$ & 2.82 & $(0.38)$ & 55.74 \\
\hline Cybianthus maginatus & Myrsinaceae & 1 & 4.21 & 4.02 & & 31.46 \\
\hline
\end{tabular}


Appendix 8. Light response curve of photosynthesis (A, $\mu \mathrm{mol} \mathrm{CO}_{2} \mathrm{~m}^{-2}$ leaf $\left.\mathrm{s}^{-1}\right)$ at $3050 \mathrm{~m}$. Given are mean values of light curves of 35 measured leaves (10 species). Error bars represent $1 \mathrm{SD}$. $\mathrm{PAR}=$ photosynthetic active radiation.

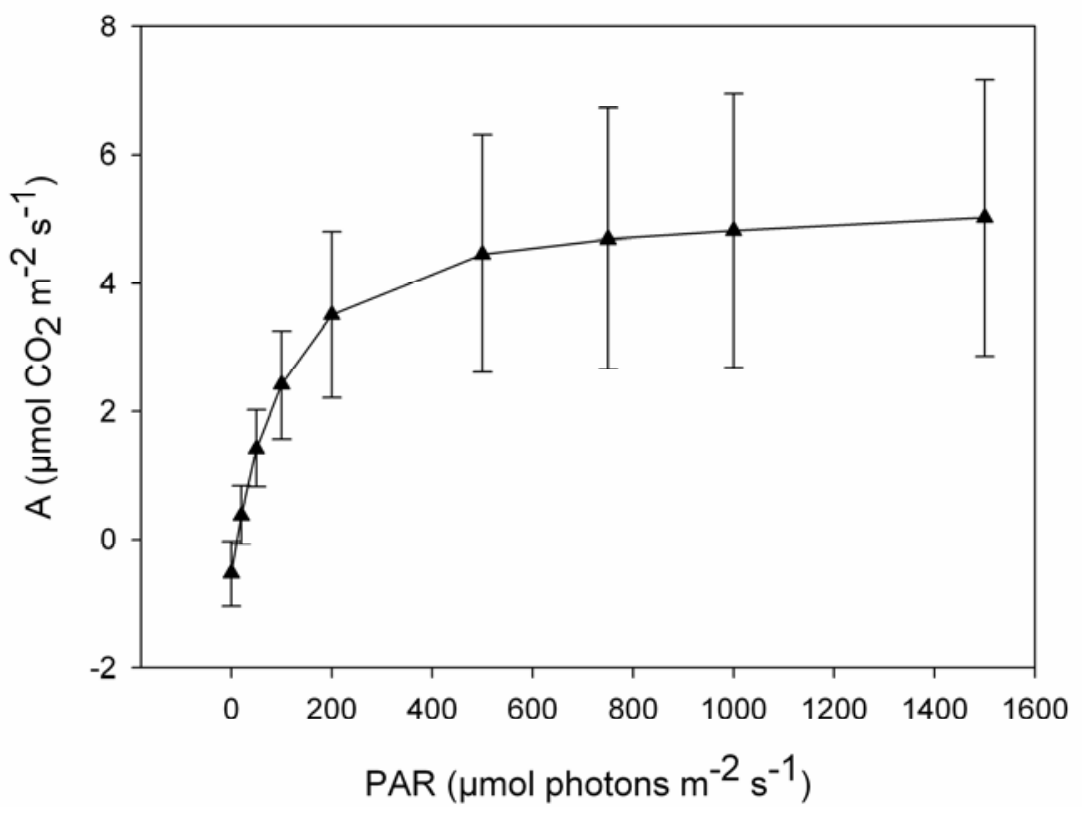




\section{ACKNOWLEDGEMENTS}

Looking back, the last three years working on that $\mathrm{PhD}$ thesis have been a very intensive time. There was not only knowledge and understanding about topics that grew, you have never been in touch with; not only lots of experiences you made and pictures you added to your imaginary pictorial - it was also one of those chances in life you grew by yourself. This would never have happen without the following people around.

First of all, I want to mention Prof. Christoph Leuschner for providing this unique opportunity to get in touch with undisturbed tropical forests and to pass my fieldwork at that marvellous place in the Andes of Southern Ecuador. I am thankful for his trust, interest and great support throughout that time.

Secondly, I am more than thankful having met Viviana Horna as my "personal" adviser; without her experience and patience I would have never come up with all the technical stuff and the problems thereafter. In that context, I want to mention Reiner Zimmermann for his invaluable knowledge, encouragement and great humour, making various joint field stays unforgettable. I also thank Manfred Küppers for his valuable advices and great interest.

For the great cooperation, data exchange and fruitful discussions I am very thankful to Sophie Graefe, Gerald Moser and Jürgen Homeier. Special thanks to Boris Rewald for shared office times.

Thanks to the following people for making my time at the ECSF a really great time: Manuela Müller, Beate and Alex Zimmermann, Rütger Rollenbeck, Sven Günther, Simone Radesma, Thorsten Peters, Pablo Ramirez, Fabian Brambach and especially Folkert Bauer. Above all, I am more than lucky to have met Florian Werner, changing a lot of things over the course of the last years. Thanks also to the Ecuadorians Tati and Rocio and kids, Maria and her family, Janeth, Abrahan and Polivio.

Special thanks to my friends, for supporting and encouraging me here and elsewhere: Ina, Julia, Daniela, Doris and Britt.

I am very thankful to my family Barbara, Wolfgang, Andrea and Matthias for plentiful love and patience. 


\section{CURriCulum VitaE}

PERSONAL DETAILS

Date of birth

Place of birth

Nationality

EDUCATION

$2005-2008$

$2002-2004$

$2000-2002$

$1997-2000$

$1986-1996$

\section{WORK EXPERIENCE}

$2005-2007$

$2003-2004$

2001

$1998-2000$

$2005-2008$

$2003-2005$

1998 - 1999
21. July 1976

Coburg, Germany

German
PhD study at the Department of Plant Ecology, Albrecht von Haller Institute for Plant Sciences, University of Göttingen, Germany

M.Sc. Program “ Tropical and International Agriculture” at the University of Göttingen, Germany

Degree obtained: M. Sc. agr.

Study of „Ecological Agriculture in the Tropics and Subtropics” at the University of Kassel, Germany

Degree obtained: Dipl. Agr. Ing.

Study of Agricultural Sciences at the Christian Albrechts University of Kiel, Germany

Gymnasium Albertinum, Coburg, Germany

High school graduation: Allgemeine Hochschulreife
PhD field work in Podocarpus National Park (Loja, Ecuador)

MSc. thesis in Santa Rosa (Argentina)

Field assistance in Adana (Turkey)

Study-related (agricultural sciences) internships in South-Africa, Nicaragua and Germany

Scientific assistant at the Department of Plant Ecology, University of Göttingen, Germany

Graduate assistant at the Institute of Agricultural Chemistry, University of Göttingen, Germany

Graduate assistant at the Institute of Plant Nutrition and Soil Science, University of Kiel, Germany 